\title{
Building Energy Codes Program: National Benefits Assessment, 1992-2040
}

OV Livingston

DB Elliott
PC Cole

R Bartlett

March 2014

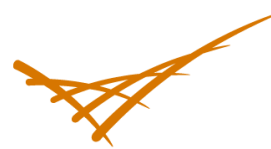

Pacific Northwest

NATIONAL LABORATORY

Proudly Operated by Battelle Since 1965 


\section{DISCLAIMER}

This report was prepared as an account of work sponsored by an agency of the United States Government. Neither the United States Government nor any agency thereof, nor Battelle Memorial Institute, nor any of their employees, makes any warranty, express or implied, or assumes any legal liability or responsibility for the accuracy, completeness, or usefulness of any information, apparatus, product, or process disclosed, or represents that its use would not infringe privately owned rights. Reference herein to any specific commercial product, process, or service by trade name, trademark, manufacturer, or otherwise does not necessarily constitute or imply its endorsement, recommendation, or favoring by the United States Government or any agency thereof, or Battelle Memorial Institute. The views and opinions of authors expressed herein do not necessarily state or reflect those of the United States Government or any agency thereof.
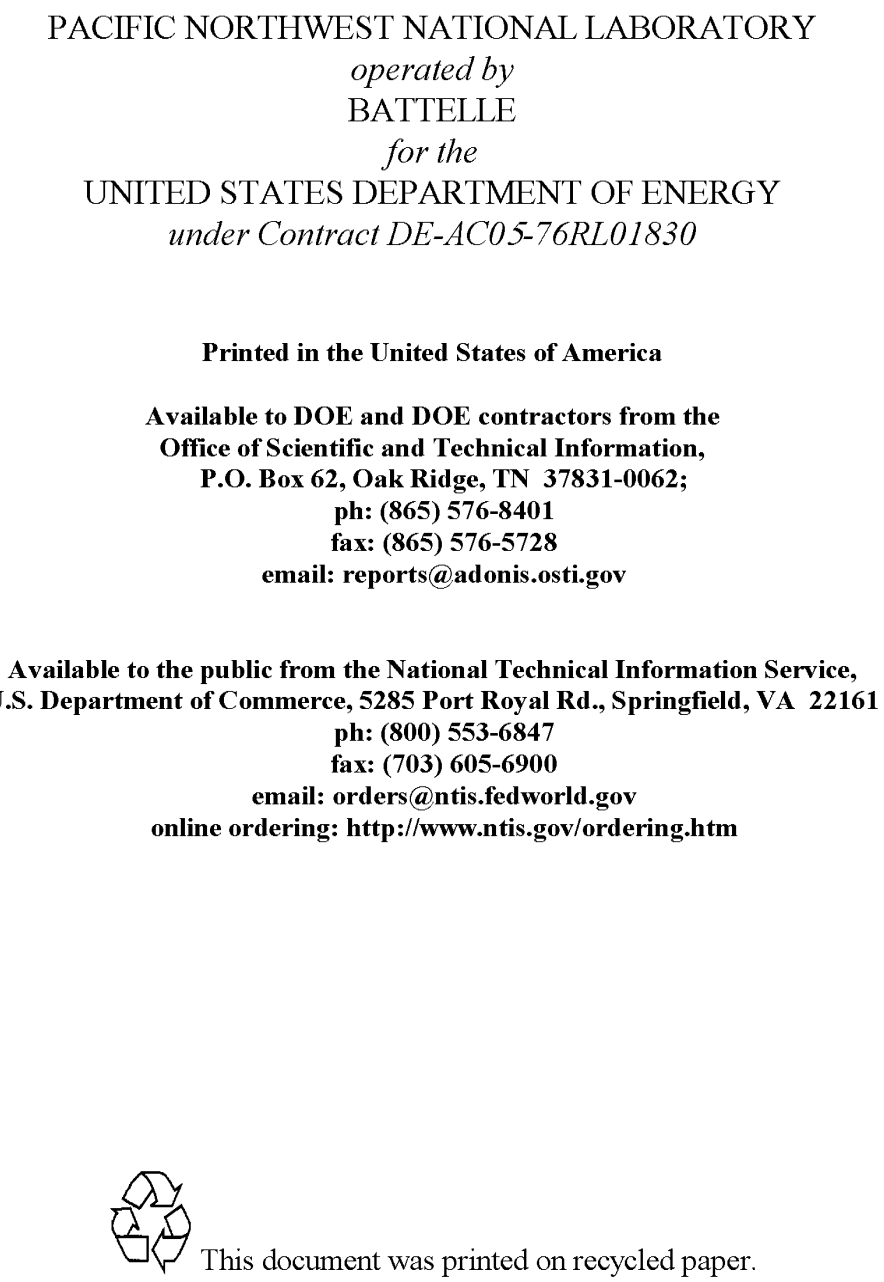

(9/2003) 


\title{
Building Energy Codes Program: National Benefits Assessment, 1992-2040
}

\author{
OV Livingston \\ PC Cole \\ DB Elliott \\ R Bartlett
}

March 2014

Prepared for

the U.S. Department of Energy

under Contract DE-AC05-76RL01830

Pacific Northwest National Laboratory

Richland, Washington 99352 


\section{Executive Summary}

Commercial and residential buildings account for approximately $41 \%$ of all energy consumption and $72 \%$ of electricity usage in the United States. Building energy codes and standards set minimum requirements for energy-efficient design and construction for new and renovated buildings, assuring reductions in energy use and greenhouse gas emissions over the life of buildings. The U.S. Department of Energy (DOE), through the Building Energy Codes Program (BECP or the Program), supports the improvement of energy efficiency in buildings. The BECP was founded in 1992 in response to the Energy Policy Act (EPAct) of 1992, which mandated that DOE participate in the model national codes development process and help states adopt and implement more efficient energy codes. Since its inception 20 years ago, BECP has become the central information resource on national energy codes and standards.

The BECP consists of an integrated portfolio of activities to increase energy efficiency in buildings. As part of its code development activities, DOE participates in the development of model energy codes and standards maintained by the International Code Council (ICC) and the American Society of Heating, Refrigerating and Air-Conditioning Engineers (ASHRAE). To help states adopt and implement progressive energy codes, DOE provides: 1) technical assistance to state and local governments to help facilitate the adoption process and 2) an array of resources to building industry stakeholders and enforcement officials to improve code compliance, including compliance software tools, training materials, and technical support.

BECP periodically assesses the impacts of its activities by estimating historical and projected energy savings, consumer savings, and avoided emissions. The Pacific Northwest National Laboratory (PNNL) conducted the codes benefits assessment in support of the BECP. Underlying the assessment is a series of calculations that estimate and compare energy savings under two scenarios: "with BECP" and "without BECP." The analysis covers the years 1992-2040 and includes comparing the nominal energy savings (assuming 100 percent adoption and compliance) attributable to different code versions, determining the applicable floor space (both residential and commercial) subject to the code, and estimating the final energy savings by adjusting nominal energy savings for the applicable floor space according to the estimated actual adoption and compliance levels. The resulting estimates of energy consumption for each scenario are compared, and the difference equals the impact of BECP activities.

The results of the Program impacts are presented in terms of energy savings, consumer cost savings, and avoided emissions. Energy savings include site, primary (source) and full-fuel-cycle (FCC) savings. Table ES.1 summarizes BECP historical and projected energy savings and net present value of consumer benefits (energy cost savings). Figure ES.1 shows the annual FFC energy savings from BECP activities from 1992-2040. A summary of emissions savings is presented in Table ES.2.

Since the inception of the Program 20 years ago, cumulative FFC energy savings from 1992- 2012 are estimated to be approximately 4.2 quads and cost savings to consumers have been more than $\$ 44$ billion. These savings have resulted primarily from the Program's activities which upgrade the model energy codes, accelerate their adoption by states and localities, and improve code compliance by means of various software tools and other types of training and technical support. The federal budgetary cost of the Program over this same period (1992-2012) was estimated to be around \$110 million, resulting in a ratio of more than $\$ 400$ in cost savings for each DOE program dollar spent. 
The estimated cumulative benefits from the Program through 2040 are also significant. The cumulative energy savings attributed to the Program total nearly 46 quads of FFC energy in 2040, or 44 quads of primary energy, equivalent to almost an entire year's worth of primary energy consumption from the U.S. residential and commercial sectors at current consumption rates. The Program is estimated to save consumers up to $\$ 230$ billion on their utility bills by 2040 . Annual carbon savings reach 36 million tons at the end of 2012, and the cumulative savings by 2040 are estimated at 3,478 million tons.

Table ES.1. Summary of Energy and Cost Savings from BECP Energy Code Activities

\begin{tabular}{|c|c|c|c|c|c|}
\hline & & $\begin{array}{l}\text { Site Energy } \\
\text { Savings, } \\
\text { quads }\end{array}$ & $\begin{array}{l}\text { Primary Energy } \\
\text { Savings, } \\
\text { quads }\end{array}$ & $\begin{array}{l}\text { FFC Energy } \\
\text { Savings, } \\
\text { quads }\end{array}$ & $\begin{array}{l}\text { Energy Cost } \\
\text { Savings } \\
\text { NPV, } \\
\text { billion 2012\$ } \\
\end{array}$ \\
\hline \multicolumn{6}{|c|}{ Historical } \\
\hline & Annual in 2012 & 0.2 & 0.48 & 0.5 & 5.0 \\
\hline & Cumulative 1992-2012 & 2.0 & 4.0 & 4.2 & 44.6 \\
\hline \multicolumn{6}{|c|}{ Projected, 2013-2040 Construction } \\
\hline & Annual in 2040 & 1.2 & 2.2 & 2.3 & 5.2 \\
\hline & Cumulative 2013-2040 & 22.0 & 40.1 & 41.6 & 185.7 \\
\hline \multicolumn{6}{|c|}{ BECP Total } \\
\hline & Annual in 2040 & 1.2 & 2.2 & 2.3 & 5.2 \\
\hline & Cumulative 1992-2040 & 24.0 & 44.1 & 45.7 & 230.3 \\
\hline (a) & \multicolumn{5}{|c|}{$\begin{array}{l}\text { Site energy savings represent direct energy savings to the consumer. Site energy savings multiplied by the energy price } \\
\text { represent energy cost savings to the consumer. }\end{array}$} \\
\hline (b) & \multicolumn{5}{|c|}{$\begin{array}{l}\text { Following the analysis methodology used by DOE's Appliance and Equipment Standards Program, site energy savings were } \\
\text { first converted to the source energy terms, which includes energy used in generation, transmission, and distribution (primary } \\
\text { energy). }\end{array}$} \\
\hline (c) & \multicolumn{5}{|c|}{$\begin{array}{l}\text { Energy used further "upstream" in the mining, processing, and transportation of fuels cycle was calculated using the NIA } \\
\text { PLUS model and added to the primary energy savings to vield full-fuel-cycle (FFC) energy savings }\end{array}$} \\
\hline
\end{tabular}




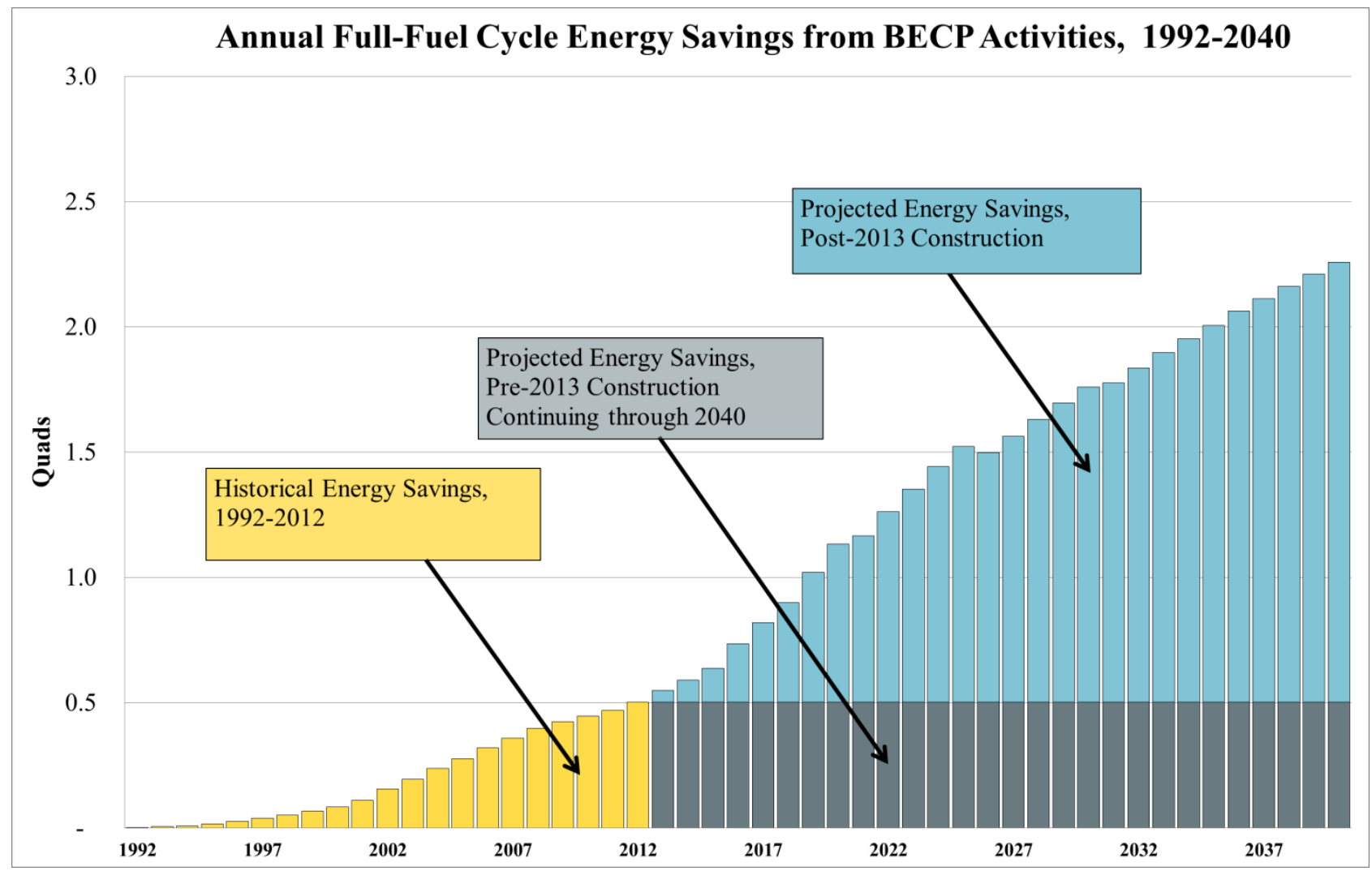

Figure ES.1. Annual Full-Fuel-Cycle Energy Savings from BECP Activities, 1992-2040

Table ES.2. Summary of Historical and Projected Emissions Savings

\begin{tabular}{|c|c|c|c|c|c|c|c|c|}
\hline & $\begin{array}{c}\mathrm{CO}_{2} \\
(\mathrm{mmt})\end{array}$ & $\begin{array}{c}\text { NO }_{x} \\
(k t)\end{array}$ & $\begin{array}{l}\text { Mercury } \\
\text { (ton) }\end{array}$ & $\begin{array}{l}\mathrm{N}_{2} \mathrm{O} \\
\text { (kt) }\end{array}$ & $\begin{array}{c}\mathrm{N}_{2} \mathrm{O} \\
\left(\mathrm{mmt} \mathrm{CO}_{2} \mathrm{eq}\right)\end{array}$ & $\begin{array}{c}\mathrm{CH}_{4} \\
\text { (kt) }\end{array}$ & $\begin{array}{c}\mathrm{CH}_{4} \\
\left(\mathrm{mmt} \mathrm{CO} \mathrm{O}_{2} \mathrm{eq}\right)\end{array}$ & $\begin{array}{l}\mathrm{SO}_{2} \\
\text { (kt) }\end{array}$ \\
\hline \multicolumn{9}{|l|}{ Historical } \\
\hline Annual in 2012 & 36 & 80 & 0.1 & 0.4 & 0.1 & 159 & 4 & 46 \\
\hline Cumulative 1992-2012 & 300 & 664 & 0.6 & 3.3 & 1.0 & 1,347 & 34 & 386 \\
\hline \multicolumn{9}{|c|}{ Projected, 2013-2040 Construction } \\
\hline Annual in 2040 & 185 & 194 & 0.4 & 1.8 & 0.5 & 796 & 20 & 116 \\
\hline Cumulative 2013-2040 & 3,178 & 3,855 & 6.9 & 32.1 & 9.6 & 14,095 & 352 & 3,489 \\
\hline \multicolumn{9}{|l|}{ BECP Total } \\
\hline Annual in 2040 & 185 & 194 & 0.4 & 1.8 & 0.5 & 796 & 20 & 116 \\
\hline Cumulative 1992-2040 & 3,478 & 4,519 & 7.6 & 35.4 & 10.5 & 15,441 & 386 & 3,875 \\
\hline
\end{tabular}

BECP's cumulative FFC savings of emissions of the greenhouse gases of carbon dioxide $\left(\mathrm{CO}_{2}\right)$, nitrous oxide $\left(\mathrm{N}_{2} \mathrm{O}\right)$, and methane $\left(\mathrm{CH}_{4}\right)$ in $\mathrm{CO}_{2}$-equivalents in Table ES.2 are almost3.9 billion metric tons. That is equivalent to three-quarters of all energy-related emissions of the United States in 2012. These benefits do not count the reduction of other energy-related air pollutants shown in Table ES.2, or billions of dollars in saved future investment in facilities to supply the natural gas, electricity, and fuel oil to the residential and commercial sectors that would no longer be required. 
This analysis also estimated the potential energy savings for 2013-2040 for residential and commercial code activities under ideal adoption and compliance conditions. The estimate represents the energy, cost, and emissions that could be saved on new post-2013 construction, as well as existing stock, with immediate code adoption and $100 \%$ compliance. Full cumulative site energy savings potential for 2013-2040 equals 42.6 quads, with residential and commercial energy code activities contributing approximately $50 \%$ each. Primary energy savings potential is 77 quads, which translates to FFC energy savings of nearly 80 quads. Cumulative energy cost savings potential equals approximately $\$ 330$ billion (2012\$). Annual $\mathrm{CO}_{2}$ savings potential reaches 461 million metric tons at the end of 2040, and the cumulative potential carbon savings by 2040 are estimated at over 6.2 billion metric tons of $\mathrm{CO}_{2}$. For more details of the energy savings potential, as well as potential cost and emissions reductions, refer to Appendix A. 


\section{Acronyms and Abbreviations}

AEO

ARRA

ASHRAE

BECP

CBECS

$\mathrm{CH}_{4}$

$\mathrm{CO}_{2}$

$\mathrm{CO}_{2} \mathrm{eq}$

DOE

EIA

EUI

FFC

$\mathrm{Hg}$

hh

HVAC

ICC

IECC

GDP

kt

$\mathrm{kWh}$

MCEC

MEC

$\mathrm{MHC}$

$\mathrm{Mt}$

$\mathrm{mmt}$

$\mathrm{N}_{2} \mathrm{O}$

NEMS

$\mathrm{NO}_{\mathrm{x}}$

NPV

PNNL

quads

RECS

TBtu
Annual Energy Outlook

American Recovery and Reinvestment Act

American Society of Heating, Refrigerating and Air-Conditioning Engineers

Building Energy Codes Program

Commercial Buildings Energy Consumption Survey

methane

carbon dioxide

carbon dioxide equivalent

U.S. Department of Energy

Energy Information Administration

energy use intensity

full-fuel-cycle

mercury

household

heating, ventilating, and air conditioning

International Code Council

International Energy Conservation Code

gross domestic product

kiloton

kilowatt-hours

Model Code for Energy Conservation

Model Energy Code

McGraw-Hill Construction

metric ton

million metric tons

nitrous oxide

National Energy Modeling System

nitrogen oxide

net present value

Pacific Northwest National Laboratory

quadrillion British thermal units

Residential Energy Consumption Survey

trillion British thermal units 


\section{Contents}

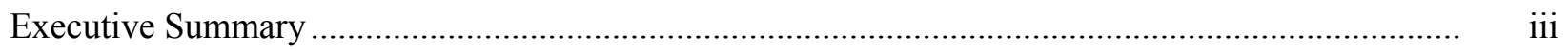

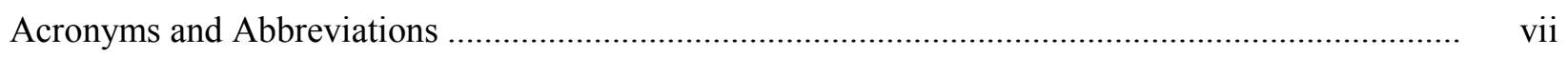

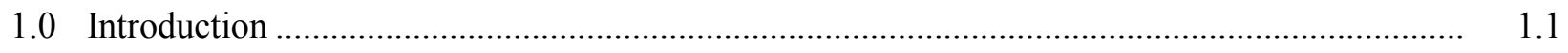

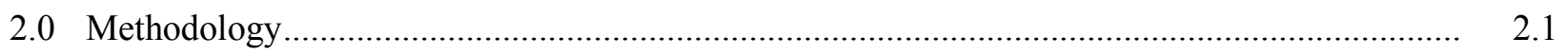

3.0 Commercial Assumptions and Estimated Results ..........................................................

3.1 Commercial Energy Codes and Standards Performance .................................................. 3.1

3.2 Commercial Floor Space Forecast .......................................................................... 3.6

3.2.1 Historical Data for New Construction and Additions to Existing Buildings ........... 3.6

3.2.2 Projected Data for New Construction and Additions to Existing Buildings ............ 3.8

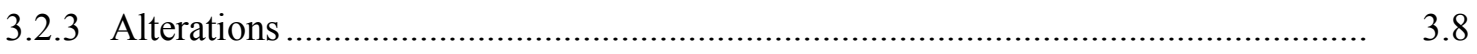

3.3 Adoption of Commercial Energy Codes and Standards................................................. 3.9

3.3.1 Historical Explicit Adoption Rate Assumptions …............................................. 3.10

3.3.2 Historical Implicit Adoption Assumptions....................................................... 3.11

3.3.3 Future Adoption Assumptions...................................................................... 3.14

3.3.4 Adoption Assumptions for the Counterfactual Scenario......................................... 3.15

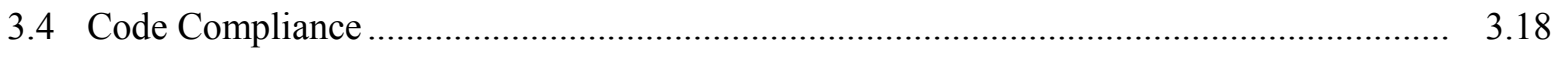

3.5 Estimated Benefits of the BECP Commercial Activities ................................................ 3.22

4.0 Residential Assumptions and Estimated Results ............................................................... 4.1

4.1 Residential Energy Code Performance........................................................................ 4.1

4.2 Residential Floor Space Forecast ............................................................................. 4.6

4.2.1 Historical Data for New Residential Construction............................................. 4.6

4.2.2 Projected Data for New Construction and Additions to Existing Residential Buildings ................................................................................................. 4.7

4.2.3 Integration of Historical and Projected Residential Data .................................... 4.8

4.3 Adoption of Residential Energy Codes ....................................................................... 4.8

4.4 Residential Energy Code Compliance.......................................................................... 4.14

4.5 Estimated Benefits of the Residential BECP Activities .................................................... 4.15

5.0 National Energy, Economic, and Environmental Benefits ................................................... 5.1

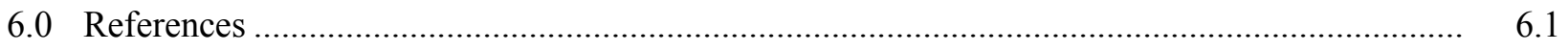

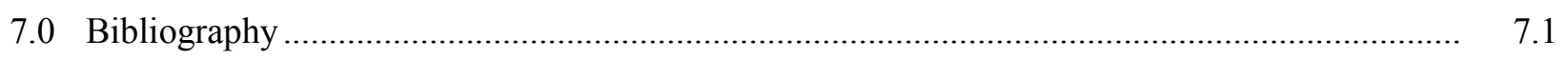

Appendix - Energy Savings Potential from More Rapid Code Adoption and Compliance, 20132040 . 


\section{Figures}

ES.1 Annual Full-Fuel-Cycle Energy Savings from BECP Activities, 1992-2040...................... v v

$2.1 \quad$ Analysis Methodology ........................................................................................ 2.1

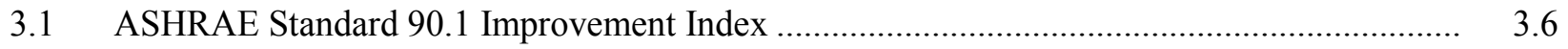

3.2 Historical and Projected Savings Streams ....................................................................... 3.22

4.1 IECC Residential Energy Improvement Index .............................................................. 4.5

\section{Tables}

ES.1 Summary of Energy and Cost Savings from BECP Energy Code Activities............................ iv

ES.2 Summary of Historical and Projected Emissions Savings .................................................. v

3.1 Prototype Floor Area Assumptions............................................................................ 3.2

3.2 State Energy Code Performance Estimates, Electricity ........................................................ 3.4

3.3 State Energy Code Performance Estimates, Natural Gas ........................................................ 3.5

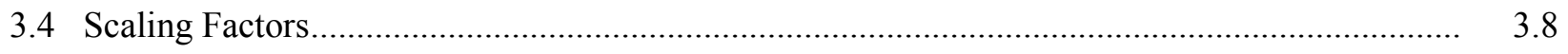

3.5 Start Year for Crediting States with Commercial Energy Code Savings Based on the Newly Adopted Code ............................................................................................................ 3.10

3.6 Explicit and Implicit Adoption Years by State and Commercial Code .................................... 3.12

3.7 State Classification for Future Commercial Energy Code Adoption........................................ 3.14

3.8 Commercial Energy Code Adoption Assumptions for Scenario "with BECP"......................... 3.16

3.9 Commercial Energy Code Adoption Assumptions for Scenario "without BECP”..................... 3.17

3.10 Compliance Assumptions for Standard 90.1, "With BECP” Scenario ...................................... 3.19

3.11 Percent Point Difference between Commercial Compliance Levels “with BECP” and

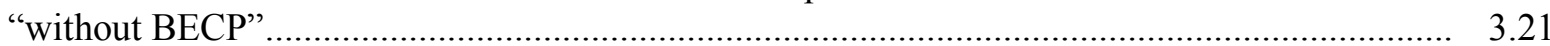

3.12 States Excluded from the BECP Commercial Benefits Calculation ......................................... 3.22

3.13 BECP Commercial Site Energy Savings ........................................................................ 3.24

3.14 BECP Commercial Primary and Full-Fuel-Cycle Energy Savings ....................................... 3.26

3.15 Summary of Energy and Cost Savings from the BECP Commercial Energy Code Activities.... 3.27

3.16 Annual Emissions Savings from the BECP Commercial Activities, Full-Fuel-Cycle ............... 3.28

3.17 Summary of Emissions Savings from the BECP Commercial Energy Code Activities.............. 3.29

3.18 National Cumulative Benefits of the BECP Commercial Activities, 1992-2040 .................... 3.29

3.19 Cumulative Consumer Benefits from BECP Commercial Codes Activities ............................. 3.31

4.1 Residential Annual Energy Use for all IECC Regulated End-Uses, Electricity ......................... 4.3

4.2 Residential Annual Energy Use for all IECC Regulated End-Uses, Natural Gas, and Heating Oil .

4.3 Start Year for Crediting States with Residential Energy Code Savings Based on the Newly Adopted Code 
4.4 Start of the Residential Savings Stream Based on Explicit and Implicit Adoption .................... 4.10

4.5 State Classifications for Future Residential Energy Code Adoption ......................................... 4.11

4.6 Residential Energy Code Adoption Assumptions for the Scenario "with BECP"..................... 4. 4.12

4.7 Residential Energy Code Adoption Assumptions for the Scenario “without BECP” "............... 4.13

4.8 Residential Code Compliance Assumptions for "With BECP" Scenario.................................... 4.14

4.9 Percent Point Difference between Residential Compliance Levels "with BECP" and "without BECP" Scenarios .

4.10 States Excluded from the BECP Residential Benefits Calculation............................................. 4.15

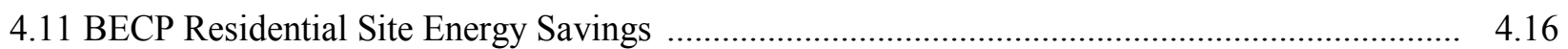

4.12 BECP Residential Primary and Full-Fuel-Cycle Energy Savings ........................................ 4.18

4.13 Summary of Energy and Cost Savings from the BECP Residential Energy Code Activities ...... 4.19

4.14 Annual Emissions Savings from the BECP Residential Activities, Full-Fuel-Cycle ................. 4.20

4.15 Summary of Emissions Savings from the BECP Residential Energy Code Activities................ 4.21

4.16 National Cumulative Benefits of the BECP Residential Activities, 1992-2040 ....................... 4.21

4.17 Cumulative Consumer Benefits from BECP Residential Energy Code Activities ..................... 4.23

5.1 Summary of Energy and Cost Savings from BECP Energy Code Activities ............................ 5.1

5.2 Breakdown of BECP Energy and Cost Savings between Commercial and Residential

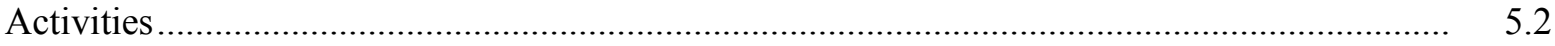

5.3 BECP Historical and Projected Primary Energy Savings ....................................................... 5.3

5.4 BECP Historical and Projected Full-Fuel-Cycle Energy Savings ............................................. 5.4

5.5 Summary of Emissions Savings from BECP Energy Code Activities ..................................... 5.5

5.6 National Benefits from BECP Energy Code Activities, 1992-2040 ....................................... 5.5

5.7 Consumer Cumulative Benefits of the BECP Activities, 1992-2040 .................................... 5.6

A.1 Base Case and Immediate Adoption Scenario, Commercial Energy Codes............................ A.2

A.2 Base Case and Immediate Adoption Scenario, Residential Energy Codes ............................ A.3

A.3 Summary of Energy and Cost Savings Potential ................................................................ A.4

A.4 Potential Site, Primary, and FFC Energy Savings ........................................................... A.4

A.5 Summary of Emissions Reduction Potential ….................................................................... A.5

A.6 National Benefits Potential, 2013-2040 ....................................................................... A.6

A.7 Consumer Cumulative Benefits Potential, 2013-2040 .................................................... A.6

A.8 Summary of Full Future Energy and Cost Savings Potential .............................................. A.7

A.9 Summary of Full Future Emissions Reduction Potential ..................................................... A.7 


\subsection{Introduction}

Buildings account for approximately $41 \%$ of all energy consumption and $72 \%$ of electricity usage in the United States. Building energy codes and standards set minimum requirements for energy-efficient design and construction for new and renovated buildings, assuring reductions in energy use and greenhouse gas emissions over the life of buildings. The U.S. Department of Energy (DOE), through the Building Energy Codes Program (BECP or the Program), supports the improvement of energy efficiency in buildings. BECP was founded in 1992 in response to the Energy Policy Act of 1992 (EPAct 1992), which mandated that DOE participate in the model national codes development process and that DOE help states adopt and implement progressive energy codes. Since its inception 20 years ago, BECP has become the central information resource on national energy codes and standards.

The BECP consists of an integrated portfolio of activities to increase energy efficiency in buildings. As part of its code development activities, DOE participates in the development of model energy codes and standards maintained by the International Code Council (ICC) and the American Society of Heating, Refrigerating and Air-Conditioning Engineers (ASHRAE). To help states adopt and implement progressive energy codes, DOE provides: 1) technical assistance to state and local governments to help facilitate the adoption process and 2) an array of resources to building industry stakeholders and enforcement officials to improve code compliance, including compliance software tools, training materials, and technical support.

BECP periodically assesses the influence of its activities by estimating historical and projected energy savings, consumer savings, and avoided emissions. This technical report describes the impacts of BECP energy code activities on the nation as a whole, expressed in terms of estimated site, primary (source), and full-fuel-cycle (FFC) energy savings, consumer energy cost savings, and emissions reductions. The analysis period included estimation of the historical (1992-2012) and projected (2013-2040) benefits of these activities. The methodology and assumptions used in the impacts analysis are discussed in detail in this report.

Impacts of the BECP are estimated under two different scenarios: "with BECP" and "without BECP." The difference between these two scenarios, in terms of energy, cost, and emissions is a measure of the Program's impact:

- The first scenario, "with BECP," is based on BECP having supported the development of more efficient national energy codes, provided technical assistance and training to states and localities, and developed and supported energy code-related materials and software. All of these activities are deemed to have improved the energy efficiency impact of the code requirements, and to have increased adoption of and compliance with building energy codes beyond what would have been likely without the Program.

- The second, "without BECP," follows the same computational steps as the first scenario, but with an alternative set of assumptions to describe what would have happened if the BECP had not been in place (i.e., a counterfactual scenario). As a result of other (i.e., non-DOE) code organizations that support building energy codes and state- and regionally-funded activities to adopt and enforce the codes, energy savings would still have occurred without the BECP, but at a slower pace and with a lower compliance rate. 
This report is organized into five sections. Section 2 explains the impact analysis methodology. Sections 3 and 4 include detailed discussion of the assumptions and estimation results for BECP commercial and residential energy code activities, respectively. Section 5 summarizes the national energy and emissions savings, and economic benefits. Section 6 provides a list of references, and Section 7 provides a bibliography. The Appendix contains an estimate of the energy savings potential for residential and commercial code activities assuming immediate adoption and full compliance. 


\subsection{Methodology}

This section describes the methodology used by PNNL to assess the impact of BECP energy code activities. Underlying the analysis is a series of calculations that estimate and compare the energy savings under two adoption and compliance scenarios: "with BECP" and "without BECP."

The steps used to calculate the "with BECP" scenario are as follows:

1. Select base (or reference) year.

2. Compare the nominal energy savings.

3. Determine applicable floor space subject to the code.

4. Estimate the final energy savings by adjusting nominal energy savings for the applicable floor space according to the estimated actual adoption and compliance levels.

These calculations rely on historical data or retrospective estimates, as well as future projections of code efficiency, adoption, and compliance to derive the energy consumption with the Program activities taking place. In the absence of reliable data or established analysis to use as bases for this analysis, the impact estimates also rely on fundamental or enabling assumptions developed based on analyst or Program experience and judgment.

To identify how much of the savings are attributable to the BECP, a second (counterfactual) scenario was used to investigate the probable impact had the Program not been in place. This second scenario, "without BECP," follows the same computational steps outlined above, but uses an alternative set of assumptions to describe what might have occurred differently without the BECP. For this analysis, BECP programmatic impacts are primarily defined as a) improvement of code energy efficiency, b) acceleration of adoption and c) increase in compliance. The nominal energy savings for the applicable floor area are adjusted for "with BECP" and "without BECP" scenarios. They are further adjusted by a different set of adoption and compliance rates. Figure 2.1 shows a brief outline of the computational steps for both scenarios.

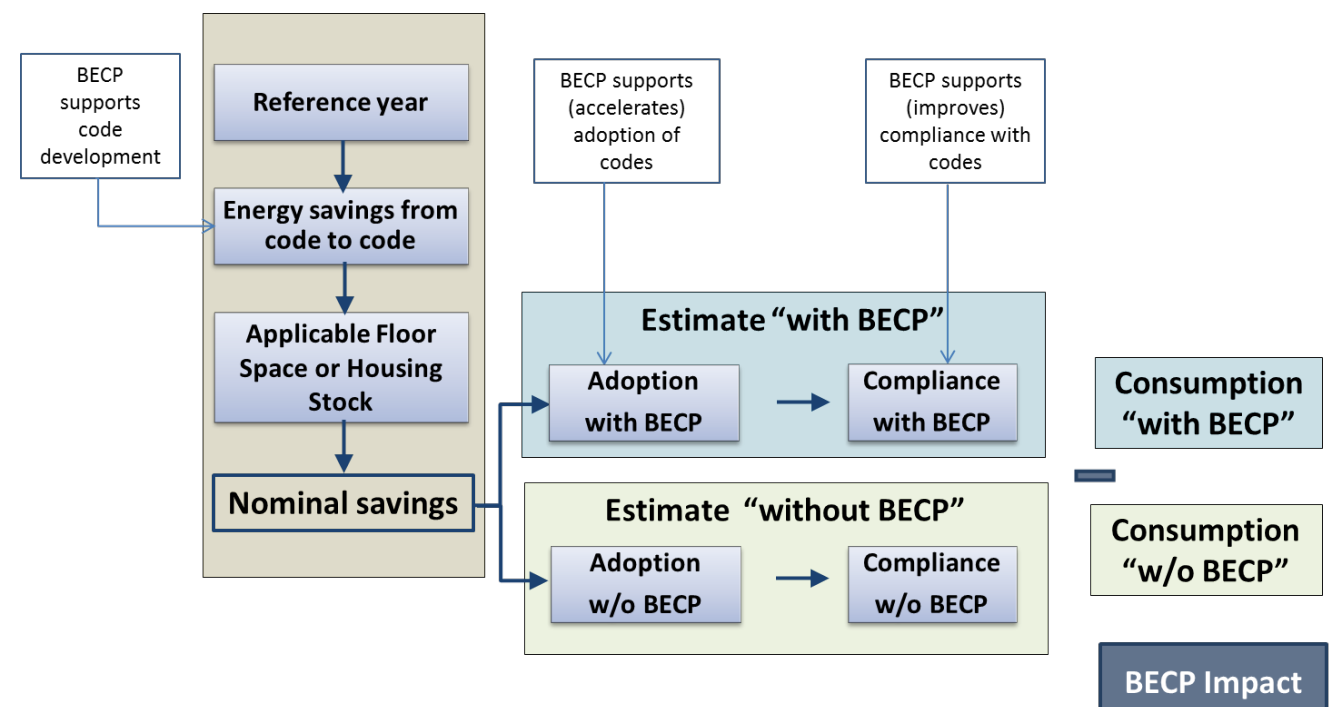

Figure 2.1. Analysis Methodology 
The difference between estimates of energy consumption under the two scenarios determines the BECP programmatic impact (i.e., the portion of achieved energy savings that can be attributed to the $\mathrm{BECP})$.

BECP selected 1992 as the base year for the impact analysis mainly because the Program was founded in 1992 in response to EPAct 1992. Other factors contributing to this decision include:

- The 1992 Model Energy Code (MEC) was mentioned in EPAct 1992, establishing it as a reasonable base year.

- Although many states had adopted ASHRAE Standard 90, the Model Code for Energy Conservation (MCEC 1977), or the MEC by the early 1980s, and a case can be made for using any one of these version years as the base year, lack of data on compliance with these codes and standards renders them infeasible as reference points.

- The use of 1992 as the reference year eliminates the need to consider an additional code level in the analysis of building practices less stringent than Standard 90A-1980. Additional code-level analysis would have added little to the accuracy of the estimates due to the aforementioned lack of data for that period.

Although using 1992 as the base year for the historical analysis might omit some of DOE's historical impact on building codes, it can be argued that most of DOE's influence on the technical requirements in these standards has occurred since 1992. DOE was not active in preparing and submitting proposed changes to the MEC during the 1980s. The majority of DOE's technically focused energy codes and standards activities in the 1980s targeted developing the technical foundation for ASHRAE Standard 90.1-1989 (ASHRAE 1990). This standard was much more rigorous than Standard 90A-1980 and thus had a greater impact on energy efficiency as states began to adopt Standard 90.1-1989 in the early 1990s.

For this analysis, estimated benefits were developed separately for commercial and residential energy codes. As such, estimates of code-to-code savings, applicable floor area, code adoption, and code compliance assumptions were developed separately as well. Section 3 contains detailed descriptions of the logic, assumptions, and estimation results for the commercial code activities, while Section 4 discusses similar points for the residential analysis. 


\subsection{Commercial Assumptions and Estimated Results}

This section discusses how the energy savings attributable to different commercial energy code versions were compared, how the applicable commercial floor space subject to the code was determined, and what adoption and compliance assumptions were used in the analysis.

\subsection{Commercial Energy Codes and Standards Performance (Code-to- Code Savings)}

PNNL assessed relative energy use for commercial buildings designed to meet building design requirements found in the 2010, 2007, and 2004 versions of ASHRAE Standard 90.1. PNNL also evaluated the energy savings achieved by using Standard 90.1-2010 (ASHRAE 2010) over its predecessors, Standard 90.1-2007 (ASHRAE 2007), and Standard 90.1-2004 (ASHRAE 2004). The estimated values were also used to infer the savings from earlier versions of the code.

The evaluation was conducted using computer simulations of prototype buildings developed by PNNL to support the quantitative analysis of DOE's Determinations on ASHRAE Standard 90.1. ${ }^{1}$ The annual energy use by fuel type and end use, extracted from the simulations, was converted to energy use intensity (EUI), expressed in energy use per square foot. Using construction weighting factors by building type and state, developed from 5 years of recent construction data, the energy use estimates were aggregated for each revision of Standard 90.1, both by building prototype and weighted across building type.

The analysis of relative energy use and energy savings for the 2004, 2007, and 2010 versions of Standard 90.1 was conducted using 16 commercial building prototypes based on published Commercial Prototype Building Models ${ }^{2}$. Every prototype building was simulated in each of the 15 U.S. climate zones used in the analyzed versions of Standard 90.1. For each climate zone, a most representative location and corresponding typical meteorological year weather file were identified, resulting in 720 climate/prototype combinations. ${ }^{3}$

The 2004, 2007, and 2010 versions of Standard 90.1 contain tables that specify efficiency requirements for heating, ventilating, and air conditioning (HVAC) and service water heating equipment. Most, but not all, of the equipment classes shown in the Standard 90.1 tables have minimum federal efficiency standards applied to them. Because mandated equipment efficiency is enforced as a manufacturing standard regardless of whether it is represented in Standard 90.1, the inclusion of the requirement in the ASHRAE standard has no separate energy impact. Therefore, it is necessary to exclude from the calculation the energy savings that would occur in new building construction due to these mandated equipment efficiency improvements. Excluding credit for this equipment in the quantitative analysis is consistent with the approach used in previous DOE Determinations. Therefore,

\footnotetext{
${ }^{1}$ For DOE's Determinations, go to http://www.energycodes.gov/regulations.

${ }^{2}$ The models are available at: http://www.energycodes.gov/development/commercial/90.1 models.

${ }^{3}$ For a more detailed discussion of the prototypes, technical assumptions, analyzed addenda, and aggregation weights, refer to the PNNL report, Achieving 30\% Goal: Energy and Cost Saving Analysis of ASHRAE/IES Standard 90.1-2010 (Thornton et al. 2011).
} 
the code-to-code savings used in the BECP commercial benefits analysis explicitly exclude savings induced by the federal equipment efficiency standards.

The results of the Standards 90.1-2004 and 90.1-2007 analysis reported in the Standard 90.1-2007 Determination (Halverson et al. 2011a) are based on equipment efficiency requirements in Standard 90.1-2004. The results of the Standards 90.1-2007 and 90.1-2010 analysis reported in the Standard 90.1-2010 Determination (Halverson et al. 2011b) are based on equipment efficiency requirements in Standard 90.1-2007. Some of the equipment efficiency requirements are different between 90.1-2004 and 90.1-2007. To compare the saving impacts of the three standards (i.e., 90.1-2004, 2007, and 2010) and exclude those differences that are not direct results of the standard improvement, the energy saving results of Standard 90.1-2004 were not directly taken from the 90.1-2007 Determination report. The savings were calculated by subtracting the percentage differences between 90.1-2004 and 90.1-2007 reported in the 90.1-2007 Determination from results of 90.1-2007 reported in the 90.1-2010 Determination. The energy saving results of 90.1-2007 and 90.1-2010 from the 90.1-2010 Determination were used in this impact analysis without modification.

EUIs for each of the compared versions were analyzed by prototype and by climate location. For each prototype building, the energy consumption for each standard was modeled based on 15 representative climate locations, covering all ASHRAE climate zones. It was assumed that the energy consumption of a building at one of the climate locations could be represented by the same building at another location within the same ASHRAE climate zone, resulting in 111 representative locations. Simulated energy consumption across the 111 locations and the building types was normalized by the building floor area. Floor area assumptions for each of the prototypes used in the normalization are included in Table 3.1.

Table 3.1. Prototype Floor Area Assumptions

\begin{tabular}{llc}
\hline Building Type & \multicolumn{1}{c}{ Building Prototype } & Prototype Floor Area $\left(\mathbf{f t}^{\mathbf{2}} \mathbf{~}\right.$ \\
\hline Office & Small Office & 5,502 \\
& Medium Office & 53,628 \\
& Large Office & 498,588 \\
Retail & Stand-Alone Retail & 24,692 \\
& Strip Mall & 22,500 \\
Education & Primary School & 73,959 \\
& Secondary School & 210,887 \\
Healthcare & Outpatient Healthcare & 40,946 \\
& Hospital & 241,501 \\
Lodging & Small Hotel & 43,202 \\
& Large Hotel & 122,120 \\
\multirow{2}{*}{ Warehouse } & Non-Refrigerated Warehouse & 52,045 \\
Food Service & Fast Food Restaurant & 2,501 \\
& Sit-Down Restaurant & 5,502 \\
Apartment & Mid-Rise Apartment & 33,741 \\
& High-Rise Apartment & 84,320 \\
\hline
\end{tabular}

Resulting EUIs per square foot of floor area were weighted across building types and representative climate locations to obtain the aggregate EUIs by state. 
To estimate the construction weights, the disaggregated construction volume data were acquired from the McGraw-Hill Construction (MHC) Project Starts Database. The MHC database obtained covers the time period 2003-2010, and depending upon the specific calculations, data from subsets of that time period were used. This MHC database was analyzed to develop detailed construction weights by climate zones, subzones, and states using the methodology outlined in Jarnagin and Bandyopadhyay (2010).

State-level aggregation produced estimates of the energy performance for the 2004, 2007, and 2010 versions of Standard 90.1 for two fuels (electricity and natural gas), and two groups of end uses (HVAC and Lighting/Other). The HVAC end use group includes heating, cooling, fan, pump, and heat rejection. Lighting/Other includes interior and exterior lighting, plug and process loads, service hot water, refrigeration, and generators. The estimates grouped by fuel type are presented in Table 3.2 and Table 3.3.

The impact analysis used state-level EUIs as a foundation for estimating the energy performance of the standards prior to Standard 90.1-2004 and following Standard 90.1-2010. For the versions predating 90.1-2004, the energy performance was estimated based on the commercial code improvement index developed by PNNL. The index is presented in Figure 3.1.

The retroactive code performance scalars for versions between Standard 90A-1980 and Standard 90.1-2001 were developed from this index using Standard 90.1-2004 as the base. For the versions prior to Standard 90.1-2004, BECP is not credited with the energy improvements related to code development. For Standards 90.1-2004, 2007, and 2010, BECP is credited with a third of the code-tocode energy efficiency improvement based on the professional judgment of the PNNL staff supporting code development. This means that if there were an $18.5 \%$ reduction in the EUI between Standards 90.1-2007 and 90.1-2010 in the "with BECP" scenario, we assumed that without DOE assistance in place, the code would have instead advanced by about $13 \%$.

For future standard versions after Standard 90.1-2010, the energy use was calculated for two scenarios ("with BECP" and "without BECP") with Standard 90.1-2010 as the base. It was assumed that "with BECP" there would be a 7\% improvement in the energy use, while a $6.3 \%$ improvement is expected without the DOE program in place, i.e., only $10 \%$ of the code-to-code energy efficiency improvement is attributed to BECP. This attribution structure is based on the professional judgment of the PNNL staff supporting code development and is consistent with BECP focusing on code development in the past and shifting more towards supporting improvement in code compliance in the future.

Nominal code-to-code savings were derived from the energy use estimates by comparing the code version that was adopted in the state to the previously active code version. Nominal energy savings were then adjusted by the compliance rates. Commercial adoption and compliance assumptions are described in Sections 3.3 and 3.4. 
Table 3.2. State Energy Code Performance Estimates, Electricity (site kWh/ $\mathrm{ft}^{2}-\mathrm{yr}$ )

\begin{tabular}{|c|c|c|c|c|c|c|}
\hline \multirow[b]{2}{*}{ State } & \multicolumn{3}{|c|}{ Electricity - HVAC } & \multicolumn{3}{|c|}{ Electricity - Light/Other } \\
\hline & STD2004 & STD2007 & STD2010 & STD2004 & STD2007 & STD2010 \\
\hline Alabama & 6.48 & 6.30 & 4.73 & 9.53 & 9.27 & 7.83 \\
\hline Alaska & 5.12 & 4.92 & 3.68 & 9.83 & 9.49 & 8.21 \\
\hline Arizona & 7.31 & 7.09 & 5.48 & 9.16 & 8.90 & 7.59 \\
\hline Arkansas & 6.39 & 6.19 & 4.58 & 9.77 & 9.47 & 7.98 \\
\hline California & 4.81 & 4.68 & 3.63 & 9.07 & 8.83 & 7.57 \\
\hline Colorado & 4.51 & 4.37 & 3.30 & 9.57 & 9.29 & 8.00 \\
\hline Connecticut & 4.82 & 4.65 & 3.54 & 9.54 & 9.24 & 7.94 \\
\hline Delaware & 6.05 & 5.84 & 4.12 & 10.72 & 10.37 & 8.95 \\
\hline District of Columbia & 3.60 & 3.55 & 2.72 & 8.37 & 8.27 & 7.25 \\
\hline Florida & 7.25 & 7.03 & 5.31 & 9.19 & 8.93 & 7.59 \\
\hline Georgia & 6.07 & 5.91 & 4.44 & 9.22 & 8.97 & 7.57 \\
\hline Hawaii & 10.08 & 9.91 & 7.91 & 9.12 & 8.92 & 7.91 \\
\hline Idaho & 4.93 & 4.75 & 3.38 & 10.26 & 9.92 & 8.41 \\
\hline Illinois & 5.16 & 4.99 & 3.69 & 9.97 & 9.67 & 8.44 \\
\hline Indiana & 4.94 & 4.79 & 3.56 & 9.40 & 9.16 & 7.85 \\
\hline Iowa & 4.58 & 4.44 & 3.41 & 9.56 & 9.31 & 7.88 \\
\hline Kansas & 5.61 & 5.42 & 3.95 & 9.91 & 9.60 & 8.09 \\
\hline Kentucky & 5.37 & 5.20 & 3.78 & 9.93 & 9.64 & 8.12 \\
\hline Louisiana & 7.51 & 7.27 & 5.44 & 9.75 & 9.46 & 8.07 \\
\hline Maine & 4.67 & 4.48 & 3.38 & 10.04 & 9.67 & 8.31 \\
\hline Maryland & 4.73 & 4.60 & 3.40 & 9.16 & 8.94 & 7.68 \\
\hline Massachusetts & 4.79 & 4.63 & 3.56 & 9.58 & 9.30 & 7.98 \\
\hline Michigan & 5.02 & 4.83 & 3.63 & 10.11 & 9.76 & 8.26 \\
\hline Minnesota & 4.77 & 4.62 & 3.48 & 9.81 & 9.53 & 8.36 \\
\hline Mississippi & 7.22 & 7.02 & 5.28 & 9.89 & 9.63 & 8.25 \\
\hline Missouri & 5.70 & 5.51 & 3.96 & 10.08 & 9.76 & 8.35 \\
\hline Montana & 5.07 & 4.87 & 3.55 & 9.97 & 9.63 & 8.28 \\
\hline Nebraska & 5.66 & 5.51 & 4.08 & 10.63 & 10.36 & 8.94 \\
\hline Nevada & 5.91 & 5.77 & 4.54 & 9.72 & 9.48 & 8.29 \\
\hline New Hampshire & 6.10 & 5.85 & 4.23 & 10.89 & 10.47 & 9.10 \\
\hline New Jersey & 5.57 & 5.44 & 4.13 & 9.96 & 9.71 & 8.56 \\
\hline New Mexico & 5.40 & 5.24 & 3.92 & 10.13 & 9.85 & 8.33 \\
\hline New York & 4.27 & 4.16 & 3.37 & 8.94 & 8.73 & 7.85 \\
\hline North Carolina & 5.96 & 5.78 & 4.27 & 9.66 & 9.38 & 8.03 \\
\hline North Dakota & 5.65 & 5.46 & 4.08 & 10.33 & 10.03 & 8.70 \\
\hline Ohio & 4.79 & 4.64 & 3.52 & 9.75 & 9.49 & 8.04 \\
\hline Oklahoma & 6.56 & 6.36 & 4.66 & 9.85 & 9.58 & 8.10 \\
\hline Oregon & 3.68 & 3.57 & 2.67 & 9.27 & 9.02 & 7.74 \\
\hline Pennsylvania & 4.94 & 4.79 & 3.63 & 9.51 & 9.25 & 7.86 \\
\hline Rhode Island & 4.37 & 4.18 & 3.18 & 8.99 & 8.64 & 7.14 \\
\hline South Carolina & 5.72 & 5.51 & 3.99 & 9.20 & 8.89 & 7.44 \\
\hline South Dakota & 4.42 & 4.30 & 3.36 & 9.90 & 9.64 & 8.20 \\
\hline Tennessee & 5.78 & 5.61 & 4.12 & 9.70 & 9.44 & 8.08 \\
\hline Texas & 6.74 & 6.56 & 4.91 & 9.36 & 9.12 & 7.77 \\
\hline Utah & 3.75 & 3.62 & 2.76 & 8.85 & 8.59 & 7.23 \\
\hline Vermont & 5.00 & 4.85 & 3.77 & 9.50 & 9.23 & 8.15 \\
\hline Virginia & 5.41 & 5.27 & 3.93 & 9.63 & 9.38 & 8.15 \\
\hline Washington & 3.81 & 3.70 & 2.75 & 9.30 & 9.05 & 7.82 \\
\hline West Virginia & 5.11 & 4.95 & 3.84 & 9.95 & 9.63 & 8.05 \\
\hline Wisconsin & 4.85 & 4.70 & 3.48 & 9.60 & 9.34 & 8.24 \\
\hline Wyoming & 4.17 & 4.06 & 3.29 & 9.85 & 9.61 & 8.13 \\
\hline
\end{tabular}


Table 3.3. State Energy Code Performance Estimates, Natural Gas (kBtu/ $\mathrm{ft}^{2}$-yr)

\begin{tabular}{|c|c|c|c|c|c|c|}
\hline \multirow[b]{2}{*}{ State } & \multicolumn{3}{|c|}{ Natural Gas - HVAC } & \multicolumn{3}{|c|}{ Natural Gas - Light/Other } \\
\hline & STD2004 & STD2007 & STD2010 & STD2004 & STD2007 & STD2010 \\
\hline Alabama & 9.66 & 8.95 & 5.35 & 10.21 & 9.57 & 9.57 \\
\hline Alaska & 42.64 & 39.49 & 27.82 & 14.41 & 13.56 & 13.55 \\
\hline Arizona & 4.89 & 4.64 & 3.29 & 8.75 & 8.28 & 8.28 \\
\hline Arkansas & 10.46 & 9.62 & 5.24 & 8.19 & 7.62 & 7.62 \\
\hline California & 5.80 & 5.50 & 3.99 & 8.25 & 7.74 & 7.74 \\
\hline Colorado & 15.69 & 14.66 & 11.87 & 9.73 & 9.22 & 9.21 \\
\hline Connecticut & 23.26 & 21.58 & 14.70 & 9.77 & 9.20 & 9.20 \\
\hline Delaware & 20.09 & 18.66 & 10.33 & 6.43 & 6.06 & 6.05 \\
\hline District of Columbia & 11.38 & 10.08 & 6.28 & 4.97 & 4.60 & 4.59 \\
\hline Florida & 6.10 & 5.76 & 3.66 & 7.65 & 7.22 & 7.21 \\
\hline Georgia & 9.79 & 9.04 & 5.35 & 10.29 & 9.61 & 9.61 \\
\hline Hawaii & 2.56 & 2.44 & 1.38 & 13.99 & 13.15 & 13.14 \\
\hline Idaho & 17.63 & 16.35 & 13.15 & 8.81 & 8.32 & 8.31 \\
\hline Illinois & 24.76 & 23.11 & 14.77 & 6.38 & 6.02 & 6.02 \\
\hline Indiana & 23.24 & 22.05 & 15.05 & 10.21 & 9.70 & 9.69 \\
\hline Iowa & 22.64 & 20.90 & 12.67 & 8.39 & 7.86 & 7.85 \\
\hline Kansas & 17.13 & 15.76 & 8.53 & 8.74 & 8.16 & 8.16 \\
\hline Kentucky & 17.17 & 16.04 & 9.41 & 7.90 & 7.50 & 7.50 \\
\hline Louisiana & 7.95 & 7.48 & 4.64 & 9.55 & 9.00 & 9.00 \\
\hline Maine & 29.12 & 26.68 & 16.85 & 11.24 & 10.54 & 10.54 \\
\hline Maryland & 14.77 & 13.73 & 8.47 & 6.68 & 6.31 & 6.31 \\
\hline Massachusetts & 22.04 & 20.40 & 13.32 & 7.23 & 6.81 & 6.81 \\
\hline Michigan & 24.47 & 22.53 & 14.76 & 9.68 & 9.13 & 9.13 \\
\hline Minnesota & 27.68 & 25.71 & 16.65 & 6.71 & 6.32 & 6.31 \\
\hline Mississippi & 9.77 & 9.14 & 5.30 & 11.40 & 10.71 & 10.70 \\
\hline Missouri & 18.20 & 16.90 & 9.62 & 7.78 & 7.33 & 7.33 \\
\hline Montana & 21.61 & 19.99 & 13.47 & 11.69 & 11.00 & 10.99 \\
\hline Nebraska & 24.99 & 23.28 & 13.94 & 9.95 & 9.36 & 9.35 \\
\hline Nevada & 7.32 & 6.85 & 5.12 & 14.15 & 13.32 & 13.32 \\
\hline New Hampshire & 28.86 & 26.59 & 17.71 & 10.29 & 9.70 & 9.69 \\
\hline New Jersey & 21.44 & 19.98 & 11.94 & 14.41 & 13.56 & 13.55 \\
\hline New Mexico & 10.59 & 9.88 & 7.59 & 11.09 & 10.39 & 10.38 \\
\hline New York & 17.45 & 16.11 & 10.48 & 8.35 & 7.85 & 7.85 \\
\hline North Carolina & 14.15 & 13.15 & 7.69 & 10.35 & 9.73 & 9.72 \\
\hline North Dakota & 30.10 & 28.23 & 19.49 & 10.54 & 9.98 & 9.98 \\
\hline Ohio & 23.21 & 21.54 & 13.21 & 8.76 & 8.22 & 8.22 \\
\hline Oklahoma & 10.68 & 9.99 & 6.16 & 10.36 & 9.75 & 9.75 \\
\hline Oregon & 13.91 & 13.07 & 9.37 & 9.47 & 8.89 & 8.89 \\
\hline Pennsylvania & 22.40 & 20.74 & 13.10 & 11.42 & 10.70 & 10.69 \\
\hline Rhode Island & 17.74 & 16.09 & 10.92 & 5.08 & 4.77 & 4.77 \\
\hline South Carolina & 9.15 & 8.49 & 5.35 & 7.46 & 7.00 & 7.00 \\
\hline South Dakota & 29.25 & 26.98 & 16.24 & 11.47 & 10.75 & 10.75 \\
\hline Tennessee & 16.70 & 15.64 & 9.45 & 9.98 & 9.39 & 9.39 \\
\hline Texas & 8.21 & 7.71 & 4.73 & 8.80 & 8.26 & 8.25 \\
\hline Utah & 13.82 & 12.79 & 10.65 & 7.25 & 6.82 & 6.81 \\
\hline Vermont & 28.37 & 26.47 & 18.52 & 16.88 & 15.87 & 15.86 \\
\hline Virginia & 17.22 & 15.96 & 9.15 & 11.55 & 10.85 & 10.85 \\
\hline Washington & 12.98 & 12.20 & 8.91 & 8.44 & 7.96 & 7.95 \\
\hline West Virginia & 20.28 & 18.36 & 11.09 & 10.78 & 10.08 & 10.07 \\
\hline Wisconsin & 29.24 & 27.59 & 18.76 & 10.27 & 9.71 & 9.70 \\
\hline Wyoming & 22.72 & 20.66 & 12.15 & 14.07 & 13.10 & 13.10 \\
\hline
\end{tabular}




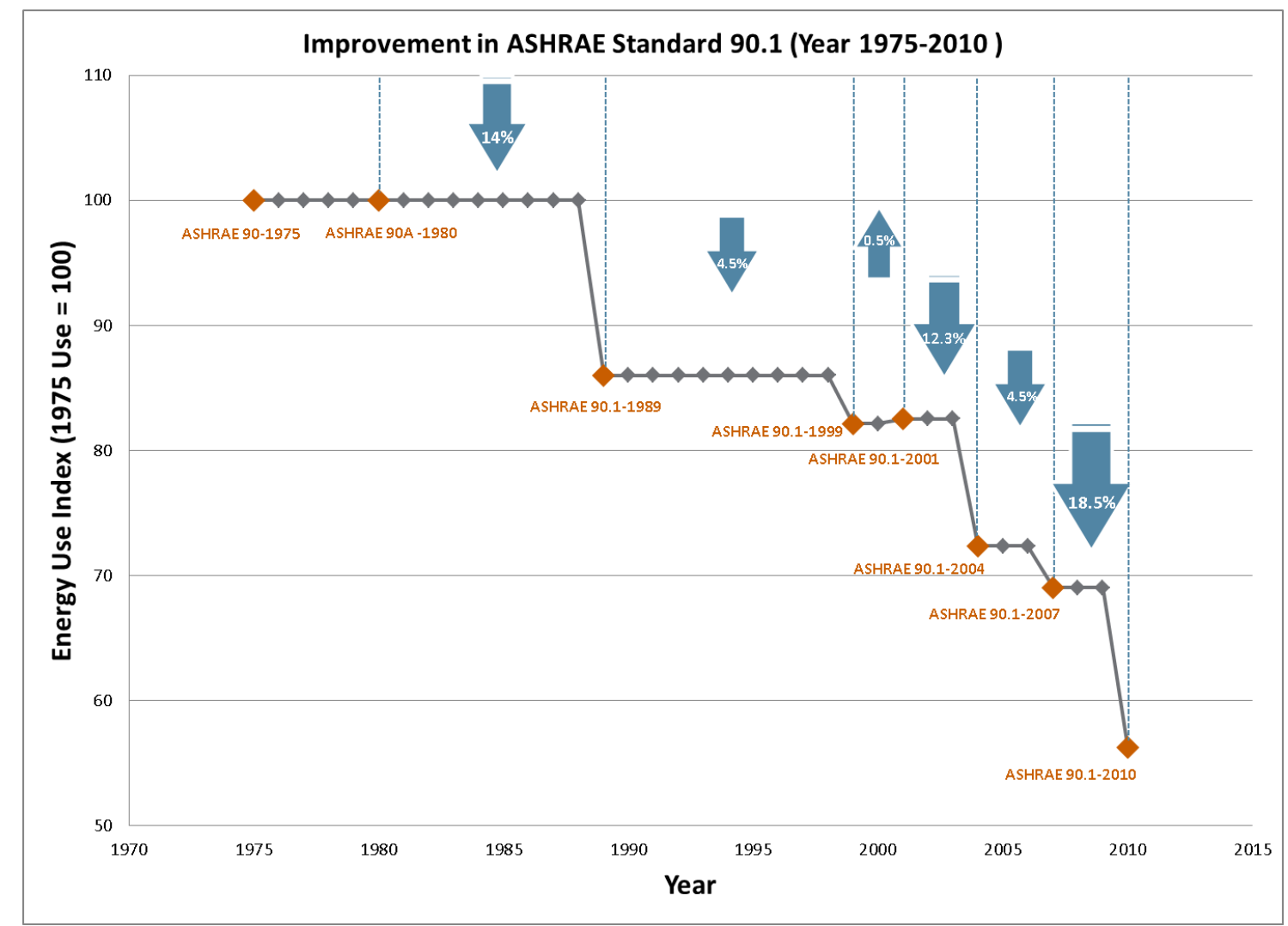

Figure 3.1. ASHRAE Standard 90.1 Improvement Index

\subsection{Commercial Floor Space Forecast}

Calculating the floor area attributable to new commercial buildings and additions to and renovations of existing commercial buildings is integral to the analysis of energy codes because the potential energy savings are estimated on the basis of gross floor area. However, there are no publicly available sources of these data for commercial buildings on a state-by-state basis. A further complication is that energy codes and standards apply not only to new floor area, but also to the floor area associated with additions to and renovations of existing buildings. The estimation of the code-applicable floor space is discussed in detail below.

Three sets of estimates, historical floor space, new floor space, and alterations, were combined to form one time-series floor space projection, in terms of millions of square feet that accounted for the space associated with both newly-constructed buildings and additions to existing buildings that is subject to the commercial energy codes and standards.

\subsubsection{Historical Data for New Construction and Additions to Existing Buildings}

For the years 1992-2002, the U.S. Census Statistical Abstract provides state-level value of construction contracts data. For the years 2003-2010, construction contract data from MHC-Dodge were obtained. These data include valuations and floor space associated with new construction and additions to existing buildings, as well as valuations (only) for alterations of existing space. 
Several steps were taken to develop a consistent time-series of incremental commercial floor space subject to energy codes from 1992-2010:

1. The census data were converted from valuations to floor space by applying a state-specific ratio representing 2003-2007 Dodge floor space added (for new construction and additions) per $\$ 1,000$ of construction value. The census data included valuations not only for commercial new construction and additions, but also for alterations and manufacturing. However, the application of this MHC-Dodge-based ratio effectively yielded floor space only for commercial new construction and additions, under the implicit assumption that the portions of census data that represent alterations and manufacturing remain constant over time.

2. The resulting 1992-2010, each state-level time series was then scaled by a multiplicative factor (scalar) so that their sum matched the reported national annual added floor space totals in the Census Statistical Abstract. This latter step corrected for lower construction costs prior to the 2003-2007 period associated with the multiplied MHC-Dodge-based ratio.

Two more adjustments were made to the resulting data:

1. A global scalar of 1.2 was applied to the state-level results. This scalar adjusted for underreporting and more closely matched floor space reported by the Energy Information Administration's (EIA's) Commercial Buildings Energy Consumption Survey (CBECS) (EIA 2006). The growth in commercial floor space was analyzed using the national floor area square footage data by year from MHC-Dodge in a spreadsheet model. While MHC-Dodge is a valuable source for measuring the amount of new floor area additions, it does not cover all new commercial building projects in the United States. MHC-Dodge does not cover smaller projects costing less than $\$ 100,000$, and other projects are not captured simply because they are not put out for bid by building contractors.

To account for this "undercoverage," the spreadsheet model was calibrated using a floor area survival function to yield similar growth rates in total U.S. commercial building floor space, as reported in various editions of the CBECS. As part of this calibration, the MHC-Dodge figures for total construction were factored up by $20 \%$ to account for underreporting of the smaller projects. ${ }^{4}$ While underreporting is likely to vary across states, there are no data to support differential adjustment factors by state; thus, the $20 \%$ factor was applied uniformly across all states.

2. Given that both the MHC-Dodge data and the Census Statistical Abstract data represent contracts to build rather than delivered space, lag factors were applied to the data. The lagged data were used as the proxy for the historical floor space completions.

\footnotetext{
${ }^{4}$ This adjustment is similar to that used by the Census Bureau to estimate private nonresidential construction in the United States. The Census Bureau adjusts data from MHC-Dodge upward by $25 \%$ to account for undercoverage of projects. (See the methodology description at http://www.census.gov/const/www/methodpage.html.) The smaller adjustment factor in the current analysis provides a better calibration with the published floor space data in EIA's CBECS.
} 


\subsubsection{Projected Data for New Construction and Additions to Existing Buildings}

To project floor space through 2040, the census and MHC-Dodge data, which covered the period through 2010, was combined with the EIA's Annual Energy Outlook (AEO) 2012 (DOE/EIA 2012), which provided the additional data through 2040. The AEO 2012 Reference Case forecasts commercial floor space added by year and by the nine census divisions. However, these floor space estimates were not utilized directly. Rather, the census division and year-specific growth rates implicit in the AEO floor space forecast were applied to the previously developed historical data.

The AEO forecast did not integrate seamlessly with the historical data, at least partially due to the substantial and prolonged impacts of the economic downturn in the roughly 2008-2011 timeframe. The MHC-Dodge-based historical data show a much deeper contraction than the AEO 2012 data. As a result, AEO 2012 growth rates, when applied to the 2010 historical data, would yield an unrealistically low longterm forecast of commercial floor space. To adjust for that, AEO growth rates were applied to an average of the 2006-2010 historical data, representing a more normal construction volume and higher base value for the forecast, rather than simply extrapolating from the 2010 data.

Although applying the AEO growth rates to a higher base floor space value remedied the issue of an unrealistically low forecast in the long-term, it also created an apparent short-term spike in the forecast. As a result, the scaling factors in Table 3.4 were applied to the floor space results for the years 2011-2014 to provide a more realistic transition from the depressed construction levels of 2010.

Table 3.4. Scaling Factors

\begin{tabular}{cc}
\hline Year & Scaling Factor \\
\hline 2011 & 0.6306 \\
2012 & 0.6203 \\
2013 & 0.7544 \\
2014 & 0.9011 \\
\hline
\end{tabular}

The resulting AEO-derived data for the years 2011-2040 are at the census division level. To apportion the census division estimates to the state level, MHC-Dodge-based 2006-2010 state shares were applied to each census division. The purpose of using a multi-year state average to smooth shares was to avoid the distortions created by the economic downturn. Several states' shares within their respective census divisions deviated dramatically from historical norms near the construction industry's trough, with Nevada in 2010 being a key example. The resulting smoothed state-level data for 2011-2040 were combined with the 1992-2010 data.

\subsubsection{Alterations}

New construction and additions to existing buildings are not the only means by which building energy codes may provide energy savings. Alterations of existing space in buildings may also be subject 
to the codes. To incorporate alterations to existing space, the analysis used state-specific alterations ratios, in combination with a renovation fraction ${ }^{5}$ :

- The period 2003-2007 was chosen to represent a period free from the distortions of the subsequent recession.

- This period was used to calculate the alterations ratios, which are the ratios of the average annual valuation of alterations to the average annual valuation of new construction and additions to existing buildings. The purchased MHC-Dodge data provided the necessary values.

- The products of the state-specific alterations ratios and the renovation fraction were multiplied by the state-level, annual floor space data associated with new construction plus additions, for the years 1992-2040. This product yields estimates of state-level, annual altered floor space subject to energy codes.

- A key assumption associated with this method is that the per-square foot cost of an energy-codeimpacting alteration across all relevant alteration types is on average close to the cost of newly-added or constructed space.

The three sets of estimates combined (adjusted historical data, new floor space forecast, and alterations) resulted in a floor space projection, in terms of millions of square feet, that accounted for the space associated with both newly-constructed buildings and additions to existing buildings that is subject to the commercial energy codes and standards.

\subsection{Adoption of Commercial Energy Codes and Standards}

The adoption of model codes presents a significant opportunity to save energy in residential and commercial buildings. The United States does not have a national energy code or standard, so energy codes are adopted at the state and local levels of government. Through the BECP, DOE provides technical assistance to state and local governments to help facilitate the acceleration of model energy codes adoption. The analysis aimed to estimate the impact of BECP activities and DOE's influence on accelerating the rate of adoption of codes and standards and/or their adoption effective date. ${ }^{6}$

Three types of adoption rate assumptions were used in the impact analysis to develop two scenarios (“with BECP" and "without BECP"):

1. Historical Explicit - adoption rates when a state explicitly adopts an energy code.

2. Historical Implicit - adoption rates where states do not explicitly adopt an energy code, but the building practices are nevertheless changing under influence from within the state or surrounding states.

\footnotetext{
${ }^{5}$ The renovation fraction is the fraction of renovation (by dollar value) that is assumed to be subject to the new energy code. In other words, this is the fraction of renovations that impact energy-related features of the space. Such features may include HVAC, envelope, and lighting. The renovation fraction was assumed to be 0.7 , the value used in past analyses and based on professional judgment.

${ }^{6}$ It is generally the case that there are two different dates associated with an energy code or standard. One is the date of adoption; that is when the document is officially "placed on the books." The other is the effective date; that is, the date when all commercial buildings are required to comply with what is adopted. Both are critical to energy savings, but the savings do not technically start to accrue until the adopted document becomes effective and required.
} 
3. Future Adoption - states are divided into three categories (aggressive, moderate, slow) based on historical energy code adoption patterns, their respective regulatory review cycle, and legislative activity. Future adoption years are projected based on each state's applicable category.

\subsubsection{Historical Explicit Adoption Rate Assumptions}

Currently, 44 states have adopted some form of a statewide commercial building energy code. In the remaining states, local municipalities and/or counties within those states are not precluded from adopting local building energy codes. BECP recognizes that in all cases, the energy code is effectively implemented at the local jurisdiction level (county or city) where building construction and permitting take place. For the purposes of this analysis, status of adoption was characterized at the state level. Status of local jurisdictional adoption was not considered due to a lack of supporting data.

Because states typically adopt the International Energy Conservation Code (IECC) and then by reference in the IECC automatically get Standard 90.1, the adoption assumption tables show the adopted versions of the IECC and reference versions of Standard 90.1.

From 1992 until the publication of Standard 90.1-1999/2001, the BECP's impact was attributable primarily to efforts to accelerate the adoption of Standard 90.1-1989 or model energy codes based on the standard and to provide materials to improve compliance with Standard 90.1-1989. Starting with Standard 90.1-2004, energy savings are also attributable to DOE efforts to improve the energy efficiency of Standard 90.1 as states updated to Standards 90.1-2004 and 90.1-2007 or associated versions of the IECC.

The years when states started receiving credit for savings induced by adopting the corresponding version of the code are presented in Table 3.5. The dates in the table are not actual adoption years, but rather show the first year when the code comes into effect and the state can be credited for the savings. July is the cutoff point for crediting the states with savings for the newly adopted code in a given year. The cutoff point is consistent with the assumption that there is typically at least a 6-month lag between the issuance of the permit and commissioning of the building. Therefore, if the code becomes effective during July or after, the construction that follows will not typically be complete in time for savings to occur in that calendar year.

Table 3.5. Start Year for Crediting States with Commercial Energy Code Savings Based on the Newly Adopted Code

\begin{tabular}{lccccc}
\hline \multicolumn{1}{c}{ State } & $\begin{array}{c}\text { MEC 92-95 } \\
\mathbf{9 0 . 1 - 1 9 8 9}\end{array}$ & $\begin{array}{c}\text { IECC 2000/2003, } \\
\mathbf{9 0 . 1 - 1 9 9 9 / 2 0 0 1}\end{array}$ & $\begin{array}{c}\text { IECC 2006 } \\
\mathbf{9 0 . 1 - 2 0 0 4}\end{array}$ & $\begin{array}{c}\text { IECC 2009 } \\
\mathbf{9 0 . 1 - 2 0 0 7}\end{array}$ & $\begin{array}{c}\text { IECC 2012 } \\
\mathbf{9 0 . 1 - 2 0 1 0}\end{array}$ \\
\hline Alabama & & & & 2013 & \\
Alaska & & & & \\
Arizona & 1995 & 2005 & & 2013 \\
Arkansas & 1992 & 2001 & 2006 & 2010 \\
California & & 2005 & 2008 & \\
Colorado & 1990 & 2005 & 2009 & 2012 \\
Connecticut & 1996 & 2004 & & 2010 \\
Delaware & 2000 & 2004 & & 2010 \\
District of Columbia & 1993 & & 2005 & 2012 \\
Florida & & & \\
\hline
\end{tabular}


Table 3.5. (contd)

\begin{tabular}{|c|c|c|c|c|c|}
\hline State & $\begin{array}{c}\text { MEC 92-95 } \\
90.1-1989 \\
\end{array}$ & $\begin{array}{c}\text { IECC 2000/2003, } \\
90.1-1999 / 2001 \\
\end{array}$ & $\begin{array}{c}\text { IECC } 2006 \\
90.1-2004 \\
\end{array}$ & $\begin{array}{c}\text { IECC 2009 } \\
90.1-2007 \\
\end{array}$ & $\begin{array}{c}\text { IECC } 2012 \\
90.1-2010 \\
\end{array}$ \\
\hline Georgia & 1996 & 2003 & 2008 & 2011 & \\
\hline Hawaii & 1995 & 2004 & 2010 & & \\
\hline Idaho & & 2005 & 2008 & 2011 & \\
\hline Illinois & & 2006 & 2008 & 2010 & 2013 \\
\hline Indiana & 1993 & & & 2010 & \\
\hline Iowa & 1993 & 2004 & 2007 & 2010 & \\
\hline \multicolumn{6}{|l|}{ Kansas } \\
\hline Kentucky & & 2005 & 2007 & 2011 & \\
\hline Louisiana & 1999 & 2005 & 2007 & 2011 & \\
\hline Maine & 1990 & 2000 & 2005 & 2011 & \\
\hline Maryland & 1997 & 2005 & 2007 & 2010 & 2012 \\
\hline Massachusetts & 1992 & 2001 & 2008 & 2010 & \\
\hline Michigan & & 2009 & & 2011 & \\
\hline Minnesota & 1999 & & 2009 & & \\
\hline Mississippi & & & & & 2013 \\
\hline \multicolumn{6}{|l|}{ Missouri } \\
\hline Montana & 1996 & 2005 & & 2010 & \\
\hline Nebraska & & 2005 & & 2012 & \\
\hline Nevada & & 2005 & 2010 & 2012 & \\
\hline New Hampshire & 1999 & 2002 & 2007 & 2010 & \\
\hline New Jersey & 1997 & 2002 & 2007 & 2011 & \\
\hline New Mexico & & 2004 & 2008 & 2012 & \\
\hline New York & 1991 & 2002 & 2008 & 2011 & \\
\hline North Carolina & 1996 & 2006 & 2009 & 2012 & \\
\hline North Dakota & & & & 2011 & \\
\hline Ohio & 1995 & 2005 & 2008 & 2012 & \\
\hline Oklahoma & & & 2011 & & \\
\hline Oregon & 1993 & 2001 & 2007 & 2010 & \\
\hline Pennsylvania & & 2004 & 2007 & 2010 & \\
\hline Rhode Island & 1997 & 2004 & 2007 & 2010 & \\
\hline South Carolina & 1997 & 2005 & 2008 & 2013 & \\
\hline \multicolumn{6}{|l|}{ South Dakota } \\
\hline Tennessee & & & 2011 & & \\
\hline Texas & & 2001 & & 2011 & \\
\hline Utah & 1995 & 2002 & 2007 & 2010 & \\
\hline Vermont & 1996 & 2001 & 2007 & 2012 & \\
\hline Virginia & 1997 & 2004 & 2006 & 2011 & \\
\hline Washington & 1994 & 2002 & 2005 & 2011 & 2013 \\
\hline West Virginia & 2003 & 2010 & & 2012 & \\
\hline Wisconsin & 1997 & & 2008 & 2012 & \\
\hline Wyoming & & & & & \\
\hline
\end{tabular}

\subsubsection{Historical Implicit Adoption Assumptions}

Although some states have not yet adopted any statewide energy code applicable to commercial buildings, it is unreasonable to believe that common building practice in these states remains at the level of Standard 90A-1980. Building efficiency has improved nationwide because of more cost-effective technologies (e.g., electronic ballasts and T-8 lamps) and the transfer of knowledge of efficient construction practices from states with building energy codes. The use of national or regional architectengineering firms in states with building energy codes influences the level of common practice in other 
states - a process characterized as a "spillover" effect. Some spillover is simply due to market forces, but it also could be driven by the adoption of energy codes in other states. Spillover is also driven by corporations that have properties in multiple states (hotels, retail stores, etc.) that have standardized designs and typically meet the more stringent energy and buildings standards in their market. Hence, it can be argued that the BECP has indirectly influenced new building efficiency in these states as well, even if the influence is difficult to quantify.

To recognize that building practices in all states will eventually meet a given historical code level, the approach in this analysis incorporated the notion of an "implicit" adoption. For the historical scenario ("with BECP"), the analysis assumed that the efficiency levels implied by Standard 90.1-1989, even in states and jurisdictions without a mandatory energy code, were reached by the late 1990s at the latest. For the 1999 and later versions of the ASHRAE standard, this time lag was assumed to be 10 years.

If a state skips one or more code cycles and then explicitly adopts a code version, then for the skipped code versions the credit starts either in the implicit adoption year, or the year when the later code version was explicitly adopted, whichever comes first. For example: North Dakota adopted the IECC 2009 (ICC 2009 ) in 2011. Thus, for IECC 2006 (ICC 2006) we show 2011, which is the lesser of the implicit adoption year (2016) and the explicit adoption year for the next code version (2011).

The code versions with a very small difference in EUIs were combined together for the analysis purposes. For example, the 2000 and 2003 versions of the IECC (ICC 2000; ICC 2003) did not have a significant difference in energy efficiency requirements (similar to Standards 90.1-1999 and 90.1-2001). For these combined code versions, the 10-year lag is added to the publication year of the first version in the combination. For example, the implicit adoption year for the 2000/2003 IECC in Alaska is 2010, not 2013 .

In reality, knowledge spillover related to energy codes is gradual, with some practices and technologies likely to be used in states without codes soon after a code has been adopted in a neighboring state. Spillover would accelerate as more states adopt codes and regional design and construction firms carry over efficiency measures to projects in states without codes (or without the most recent national model code). This analysis did not incorporate the gradual nature of this process because of a lack of data to justify selection of any particular smoothing method; rather, it assumed a sudden, 1-year transition to the newer, more energy-efficient practices (code level) once states met the 10-year threshold.

Table 3.6 shows the start of the savings stream for both explicit and implicit adoption years. Implicit adoption years are highlighted in orange.

Table 3.6. Explicit and Implicit Adoption Years by State and Commercial Code

\begin{tabular}{l|ccccc}
\hline State & MEC 92-95 & IECC 2000/2003, & IECC 2006 & IECC 2009 & IECC 2012 \\
90.1-1989 & $\mathbf{9 0 . 1 - 1 9 9 9 / 2 0 0 1}$ & $\mathbf{9 0 . 1 - 2 0 0 4}$ & $\mathbf{9 0 . 1 - 2 0 0 7}$ & $\mathbf{9 0 . 1 - 2 0 1 0}$ \\
\hline Alabama & 2002 & 2010 & 2013 & 2013 & \\
Alaska & 2002 & 2010 & 2016 & & \\
Arizona & 2002 & 2010 & 2016 & & \\
Arkansas & 1995 & 2005 & 2013 & 2013 & \\
California & 1992 & 2001 & 2006 & 2010 & \\
Colorado & 2002 & 2005 & 2008 & & \\
Connecticut & 1990 & 2005 & 2009 & 2012 &
\end{tabular}


Table 3.6. (contd)

\begin{tabular}{|c|c|c|c|c|c|}
\hline State & $\begin{array}{c}\text { MEC 92-95 } \\
90.1-1989\end{array}$ & $\begin{array}{l}\text { IECC 2000/2003, } \\
90.1-1999 / 2001\end{array}$ & $\begin{array}{c}\text { IECC } 2006 \\
90.1-2004\end{array}$ & $\begin{array}{c}\text { IECC 2009 } \\
90.1-2007\end{array}$ & $\begin{array}{c}\text { IECC } 2012 \\
90.1-2010\end{array}$ \\
\hline Delaware & 1996 & 2004 & 2010 & 2010 & \\
\hline District of Columbia & 2000 & 2004 & 2010 & 2010 & \\
\hline Florida & 1993 & 2005 & 2005 & 2012 & \\
\hline Georgia & 1996 & 2003 & 2008 & 2011 & \\
\hline Hawaii & 1995 & 2004 & 2010 & & \\
\hline Idaho & 2002 & 2005 & 2008 & 2011 & \\
\hline Illinois & 2002 & 2006 & 2008 & 2010 & 2013 \\
\hline Indiana & 1993 & 2010 & 2010 & 2010 & \\
\hline Iowa & 1993 & 2004 & 2007 & 2010 & \\
\hline Kansas & 2002 & 2010 & 2016 & & \\
\hline Kentucky & 2002 & 2005 & 2007 & 2011 & \\
\hline Louisiana & 1999 & 2005 & 2007 & 2011 & \\
\hline Maine & 1990 & 2000 & 2005 & 2011 & \\
\hline Maryland & 1997 & 2005 & 2007 & 2010 & 2012 \\
\hline Massachusetts & 1992 & 2001 & 2008 & 2010 & \\
\hline Michigan & 2002 & 2009 & 2011 & 2011 & \\
\hline Minnesota & 1999 & 2009 & 2009 & & \\
\hline Mississippi & 2002 & 2010 & 2013 & 2013 & 2013 \\
\hline Missouri & 2002 & 2010 & 2016 & & \\
\hline Montana & 1996 & 2005 & 2010 & 2010 & \\
\hline Nebraska & 2002 & 2005 & 2012 & 2012 & \\
\hline Nevada & 2002 & 2005 & 2010 & 2012 & \\
\hline New Hampshire & 1999 & 2002 & 2007 & 2010 & \\
\hline New Jersey & 1997 & 2002 & 2007 & 2011 & \\
\hline New Mexico & 2002 & 2004 & 2008 & 2012 & \\
\hline New York & 1991 & 2002 & 2008 & 2011 & \\
\hline North Carolina & 1996 & 2006 & 2009 & 2012 & \\
\hline North Dakota & 2002 & 2010 & 2011 & 2011 & \\
\hline Ohio & 1995 & 2005 & 2008 & 2012 & \\
\hline Oklahoma & 2002 & 2010 & 2011 & & \\
\hline Oregon & 1993 & 2001 & 2007 & 2010 & \\
\hline Pennsylvania & 2002 & 2004 & 2007 & 2010 & \\
\hline Rhode Island & 1997 & 2004 & 2007 & 2010 & \\
\hline South Carolina & 1997 & 2005 & 2008 & 2013 & \\
\hline South Dakota & 2002 & 2010 & 2016 & & \\
\hline Tennessee & 2002 & 2010 & 2011 & & \\
\hline Texas & 2001 & 2001 & 2011 & 2011 & \\
\hline Utah & 1995 & 2002 & 2007 & 2010 & \\
\hline Vermont & 1996 & 2001 & 2007 & 2012 & \\
\hline Virginia & 1997 & 2004 & 2006 & 2011 & \\
\hline Washington & 1994 & 2002 & 2005 & 2011 & 2013 \\
\hline West Virginia & 2003 & 2010 & 2012 & 2012 & \\
\hline Wisconsin & 1997 & 2008 & 2008 & 2012 & \\
\hline Wyoming & 2002 & 2010 & 2016 & & \\
\hline
\end{tabular}




\subsubsection{Future Adoption Assumptions}

The first step in projecting future code adoption was to categorize the states based on historical explicit adoption behavior and existing practices. Each category was then assigned a discrete period of years representing the lag between the code version year and adoption year in order to forecast future code adoption for this analysis. Each state was assigned to one of three categories:

1. A = Aggressive; a state that consistently adopts the most recent published code OR within $1-3$ years of published code ( a gap $=\leq 3$ years)

Example: Maryland has consistently adopted the most recent published codes over the past decade. The last adoption (of the 2012 IECC) occurred in 2012. Maryland is considered aggressive (adoption $<3$ years of published code).

Assumption of future adoption $=1$ year is added after published code

2. $\mathrm{M}=$ Moderate; a state that skips one published code cycle OR exceeds 3 years but less than 6 years between adoption (a gap $=>3$ years and $\leq 6$ years)

Example: Idaho adopted the 2009 IECC in 2010 and plans to adopt the 2012 IECC in 2015 or later. Idaho exceeds 3 years since previous adoption but not greater than 6 years.

\section{Assumption of future adoption $=4$ years are added after published code}

3. $\mathrm{S}=$ Slow; a state that skips more than one published code OR exceeds (in years) two published codes (a gap $>6$ years) OR a state without any statewide adoption

Example: Arkansas is categorized as slow, with an 8-year gap between adoptions even though it adopted Standard 90.1-2007/2009 IECC in 2013. Arkansas' adoption history assumes a long gap before the next adoption.

\section{Assumption of future adoption $=7$ years are added after published code}

State classifications and future adoption lag are presented in Table 3.7. There are six states whose classification varies between residential and commercial: Kentucky, Louisiana, Utah, Vermont, Virginia, and Wisconsin.

Table 3.7. State Classification for Future Commercial Energy Code Adoption

\begin{tabular}{lll}
\hline \multicolumn{1}{c}{$\begin{array}{c}\text { Aggressive } \\
\text { (code version year }+1 \text { year) }\end{array}$} & \multicolumn{1}{c}{$\begin{array}{c}\text { Moderate } \\
\text { (code version year }+4 \text { years) }\end{array}$} & \multicolumn{1}{c}{$\begin{array}{c}\text { Slow } \\
\text { (code version year }+7 \text { years) }\end{array}$} \\
\hline California & Connecticut & Alabama \\
Florida & Delaware & Alaska \\
Georgia & District of Columbia & Arizona \\
Illinois & Idaho & Arkansas \\
Iowa & Kentucky & Colorado \\
Maryland & Louisiana & Hawaii \\
Massachusetts & Maine & Indiana \\
New Hampshire & Michigan & Kansas \\
New York & Montana & Minnesota \\
North Carolina & Nebraska & Mississippi \\
\hline
\end{tabular}


Table 3.7. (contd)

\begin{tabular}{lll}
\hline \multicolumn{1}{c}{$\begin{array}{c}\text { Aggressive } \\
\text { (code version year }+1 \text { year) }\end{array}$} & \multicolumn{1}{c}{$\begin{array}{c}\text { Moderate } \\
\text { (code version year }+4 \text { years })\end{array}$} & \multicolumn{1}{c}{$\begin{array}{c}\text { Slow } \\
\text { (code version year }+7 \text { years) }\end{array}$} \\
\hline Oregon & Nevada & Missouri \\
Rhode Island & New Jersey & North Dakota \\
Utah & New Mexico & Oklahoma \\
Washington & South Dakota \\
& Pennsylvania & Tennessee \\
& South Carolina & West Virginia \\
& Texas & Wyoming \\
& Vermont & \\
& Virginia & \\
& Wisconsin & \\
& & \\
\end{tabular}

\subsubsection{Adoption Assumptions for the Counterfactual (without BECP) Scenario}

This analysis assumed that DOE efforts accelerated the adoption of the most recently published model energy code or standard (or equivalent). That is, with a favorable political and fiscal climate, some states would generally adopt an updated model code or standard within a few years without federal assistance. $^{7}$

A more difficult issue is how to attribute benefits from the spillover process to the BECP. Because the analysis assumed that adoption occurs all at once in a state in a single year, the calculation methodology did not account for spillover effects from other states for the state undergoing adoption in that year. However, the implicit adoption of codes is accelerated as a result of national codes and standards development and deployment activities. Without the DOE activities, the spillover effect in states without a statewide code would have occurred at a slower rate; therefore, implicit adoption would have been delayed as well.

To develop effective adoption year estimates for the counterfactual analysis, each category of states was assigned a discrete period of years. This was intended to capture the BECP influence on accelerating the adoption of: a) an updated energy code or standard where one existed, or b) a new energy code or standard where one did not previously exist. To stay consistent with the state groupings for future code adoption, three sets of lags were used to describe how adoption would likely evolve without BECP:

- For states with aggressive future adoption, one more year was added to the effective adoption year in the "with BECP" scenario.

- For states with moderate future adoption, a lag of 6 years was added to the "with BECP" adoption year.

- For states with a slow adoption rate, only 3 years were added to the "with BECP” adoption year.

A full set of adoption assumptions for both scenarios (with and without BECP) is included in Table 3.8 and Table 3.9. Projected adoption years are highlighted in grey.

\footnotetext{
${ }^{7}$ This is typical for cases where the energy code is a component of an entire building regulatory package that includes building, fire, electrical, mechanical, plumbing, and other codes that are adopted on a regular 3-year cycle, generally 12 to 18 months after their publication by the organization publishing those codes.
} 
Table 3.8. Commercial Energy Code Adoption Assumptions for Scenario "with BECP"

\begin{tabular}{|c|c|c|c|c|c|c|c|c|c|c|c|}
\hline & & $\begin{array}{c}\text { MEC } \\
92-95, \\
90.1- \\
1989\end{array}$ & $\begin{array}{c}\text { IECC } \\
2000 / 2003 \\
90.1- \\
1999 / 2001\end{array}$ & $\begin{array}{c}\text { IECC } \\
2006 \\
90.1- \\
2004\end{array}$ & $\begin{array}{l}\text { IECC } \\
2009 \\
90.1- \\
2007 \\
\end{array}$ & $\begin{array}{l}\text { IECC } \\
2012 \\
90.1- \\
2010\end{array}$ & $\begin{array}{c}\text { IECC } \\
2015 \\
90.1- \\
2013\end{array}$ & $\begin{array}{c}\text { IECC } \\
2018 \\
90.1- \\
2016\end{array}$ & $\begin{array}{l}\text { IECC } \\
2021 \\
90.1- \\
2019\end{array}$ & $\begin{array}{l}\text { IECC } \\
2024 \\
90.1- \\
2022\end{array}$ & $\begin{array}{c}\text { IECC } \\
2027 \\
90.1- \\
2025\end{array}$ \\
\hline $\mathrm{S}$ & Alabama & 2002 & 2010 & 2013 & 2013 & 2019 & 2022 & 2025 & 2028 & 2031 & 2034 \\
\hline $\mathrm{S}$ & Alaska & 2002 & 2010 & 2016 & 2016 & 2019 & 2022 & 2025 & 2028 & 2031 & 2034 \\
\hline $\mathrm{S}$ & Arizona & 2002 & 2010 & 2016 & 2016 & 2019 & 2022 & 2025 & 2028 & 2031 & 2034 \\
\hline $\mathrm{S}$ & Arkansas & 1995 & 2005 & 2013 & 2013 & 2019 & 2022 & 2025 & 2028 & 2031 & 2034 \\
\hline A & California & 1992 & 2001 & 2006 & 2010 & 2013 & 2016 & 2019 & 2022 & 2025 & 2028 \\
\hline $\mathrm{S}$ & Colorado & 2002 & 2005 & 2008 & 2016 & 2019 & 2022 & 2025 & 2028 & 2031 & 2034 \\
\hline M & Connecticut & 1990 & 2005 & 2009 & 2012 & 2016 & 2019 & 2022 & 2025 & 2028 & 2031 \\
\hline $\mathrm{M}$ & Delaware & 1996 & 2004 & 2010 & 2010 & 2016 & 2019 & 2022 & 2025 & 2028 & 2031 \\
\hline M & $\begin{array}{l}\text { District of } \\
\text { Columbia }\end{array}$ & 2000 & 2004 & 2010 & 2010 & 2016 & 2019 & 2022 & 2025 & 2028 & 2031 \\
\hline A & Florida & 1993 & 2005 & 2005 & 2012 & 2013 & 2016 & 2019 & 2022 & 2025 & 2028 \\
\hline $\mathrm{A}$ & Georgia & 1996 & 2003 & 2008 & 2011 & 2013 & 2016 & 2019 & 2022 & 2025 & 2028 \\
\hline $\mathrm{S}$ & Hawaii & 1995 & 2004 & 2010 & 2016 & 2019 & 2022 & 2025 & 2028 & 2031 & 2034 \\
\hline $\mathrm{M}$ & Idaho & 2002 & 2005 & 2008 & 2011 & 2016 & 2019 & 2022 & 2025 & 2028 & 2031 \\
\hline A & Illinois & 2002 & 2006 & 2008 & 2010 & 2013 & 2016 & 2019 & 2022 & 2025 & 2028 \\
\hline $\mathrm{S}$ & Indiana & 1993 & 2010 & 2010 & 2010 & 2019 & 2022 & 2025 & 2028 & 2031 & 2034 \\
\hline $\mathrm{A}$ & Iowa & 1993 & 2004 & 2007 & 2010 & 2013 & 2016 & 2019 & 2022 & 2025 & 2028 \\
\hline $\mathrm{S}$ & Kansas & 2002 & 2010 & 2016 & 2016 & 2019 & 2022 & 2025 & 2028 & 2031 & 2034 \\
\hline $\mathrm{M}$ & Kentucky & 2002 & 2005 & 2007 & 2011 & 2016 & 2019 & 2022 & 2025 & 2028 & 2031 \\
\hline $\mathrm{M}$ & Louisiana & 1999 & 2005 & 2007 & 2011 & 2016 & 2019 & 2022 & 2025 & 2028 & 2031 \\
\hline $\mathrm{M}$ & Maine & 1990 & 2000 & 2005 & 2011 & 2016 & 2019 & 2022 & 2025 & 2028 & 2031 \\
\hline A & Maryland & 1997 & 2005 & 2007 & 2010 & 2012 & 2016 & 2019 & 2022 & 2025 & 2028 \\
\hline $\mathrm{A}$ & Massachusetts & 1992 & 2001 & 2008 & 2010 & 2013 & 2016 & 2019 & 2022 & 2025 & 2028 \\
\hline $\mathrm{M}$ & Michigan & 2002 & 2009 & 2011 & 2011 & 2016 & 2019 & 2022 & 2025 & 2028 & 2031 \\
\hline $\mathrm{S}$ & Minnesota & 1999 & 2009 & 2009 & 2016 & 2019 & 2022 & 2025 & 2028 & 2031 & 2034 \\
\hline $\mathrm{S}$ & Mississippi & 2002 & 2010 & 2013 & 2013 & 2013 & 2022 & 2025 & 2028 & 2031 & 2034 \\
\hline $\mathrm{S}$ & Missouri & 2002 & 2010 & 2016 & 2016 & 2019 & 2022 & 2025 & 2028 & 2031 & 2034 \\
\hline M & Montana & 1996 & 2005 & 2010 & 2010 & 2016 & 2019 & 2022 & 2025 & 2028 & 2031 \\
\hline M & Nebraska & 2002 & 2005 & 2012 & 2012 & 2016 & 2019 & 2022 & 2025 & 2028 & 2031 \\
\hline $\mathrm{M}$ & Nevada & 2002 & 2005 & 2010 & 2012 & 2016 & 2019 & 2022 & 2025 & 2028 & 2031 \\
\hline $\mathrm{A}$ & New Hampshire & 1999 & 2002 & 2007 & 2010 & 2013 & 2016 & 2019 & 2022 & 2025 & 2028 \\
\hline $\mathrm{M}$ & New Jersey & 1997 & 2002 & 2007 & 2011 & 2016 & 2019 & 2022 & 2025 & 2028 & 2031 \\
\hline M & New Mexico & 2002 & 2004 & 2008 & 2012 & 2016 & 2019 & 2022 & 2025 & 2028 & 2031 \\
\hline A & New York & 1991 & 2002 & 2008 & 2011 & 2013 & 2016 & 2019 & 2022 & 2025 & 2028 \\
\hline A & North Carolina & 1996 & 2006 & 2009 & 2012 & 2013 & 2016 & 2019 & 2022 & 2025 & 2028 \\
\hline $\mathrm{S}$ & North Dakota & 2002 & 2010 & 2011 & 2011 & 2019 & 2022 & 2025 & 2028 & 2031 & 2034 \\
\hline M & Ohio & 1995 & 2005 & 2008 & 2012 & 2016 & 2019 & 2022 & 2025 & 2028 & 2031 \\
\hline $\mathrm{S}$ & Oklahoma & 2002 & 2010 & 2011 & 2016 & 2019 & 2022 & 2025 & 2028 & 2031 & 2034 \\
\hline $\mathrm{A}$ & Oregon & 1993 & 2001 & 2007 & 2010 & 2013 & 2016 & 2019 & 2022 & 2025 & 2028 \\
\hline $\mathrm{M}$ & Pennsylvania & 2002 & 2004 & 2007 & 2010 & 2016 & 2019 & 2022 & 2025 & 2028 & 2031 \\
\hline $\mathrm{A}$ & Rhode Island & 1997 & 2004 & 2007 & 2010 & 2013 & 2016 & 2019 & 2022 & 2025 & 2028 \\
\hline $\mathrm{M}$ & South Carolina & 1997 & 2005 & 2008 & 2013 & 2016 & 2019 & 2022 & 2025 & 2028 & 2031 \\
\hline $\mathrm{S}$ & South Dakota & 2002 & 2010 & 2016 & 2016 & 2019 & 2022 & 2025 & 2028 & 2031 & 2034 \\
\hline $\mathrm{S}$ & Tennessee & 2002 & 2010 & 2011 & 2016 & 2019 & 2022 & 2025 & 2028 & 2031 & 2034 \\
\hline $\mathrm{M}$ & Texas & 2001 & 2001 & 2011 & 2011 & 2016 & 2019 & 2022 & 2025 & 2028 & 2031 \\
\hline A & Utah & 1995 & 2002 & 2007 & 2010 & 2013 & 2016 & 2019 & 2022 & 2025 & 2028 \\
\hline M & Vermont & 1996 & 2001 & 2007 & 2012 & 2016 & 2019 & 2022 & 2025 & 2028 & 2031 \\
\hline $\mathrm{M}$ & Virginia & 1997 & 2004 & 2006 & 2011 & 2016 & 2019 & 2022 & 2025 & 2028 & 2031 \\
\hline $\mathrm{A}$ & Washington & 1994 & 2002 & 2005 & 2011 & 2013 & 2016 & 2019 & 2022 & 2025 & 2028 \\
\hline $\mathrm{S}$ & West Virginia & 2003 & 2010 & 2012 & 2012 & 2019 & 2022 & 2025 & 2028 & 2031 & 2034 \\
\hline M & Wisconsin & 1997 & 2008 & 2008 & 2012 & 2016 & 2019 & 2022 & 2025 & 2028 & 2031 \\
\hline $\mathrm{S}$ & Wyoming & 2002 & 2010 & 2016 & 2016 & 2019 & 2022 & 2025 & 2028 & 2031 & 2034 \\
\hline
\end{tabular}


Table 3.9. Commercial Energy Code Adoption Assumptions for Scenario "without BECP"

\begin{tabular}{|c|c|c|c|c|c|c|c|c|c|c|c|}
\hline & & $\begin{array}{l}\text { MEC } \\
92-95 \\
90.1- \\
1989\end{array}$ & $\begin{array}{c}\text { IECC } \\
2000 / 2003 \\
90.1- \\
1999 / 2001 \\
\end{array}$ & $\begin{array}{c}\text { IECC } \\
2006 \\
90.1- \\
2004 \\
\end{array}$ & $\begin{array}{c}\text { IECC } \\
2009 \\
90.1- \\
2007 \\
\end{array}$ & $\begin{array}{c}\text { IECC } \\
2012 \\
90.1- \\
2010 \\
\end{array}$ & $\begin{array}{c}\text { IECC } \\
2015 \\
90.1- \\
2013 \\
\end{array}$ & $\begin{array}{c}\text { IECC } \\
2018 \\
90.1- \\
2016 \\
\end{array}$ & $\begin{array}{c}\text { IECC } \\
2021 \\
90.1- \\
2019 \\
\end{array}$ & $\begin{array}{c}\text { IECC } \\
2024 \\
90.1- \\
2022 \\
\end{array}$ & $\begin{array}{l}\text { IECC } \\
2027 \\
90.1- \\
2025\end{array}$ \\
\hline $\mathrm{S}$ & Alabama & 2005 & 2013 & 2016 & 2016 & 2022 & 2025 & 2028 & 2031 & 2034 & 2037 \\
\hline $\mathrm{S}$ & Alaska & 2005 & 2013 & 2019 & 2019 & 2022 & 2025 & 2028 & 2031 & 2034 & 2037 \\
\hline $\mathrm{S}$ & Arizona & 2005 & 2013 & 2019 & 2019 & 2022 & 2025 & 2028 & 2031 & 2034 & 2037 \\
\hline $\mathrm{S}$ & Arkansas & 1998 & 2008 & 2016 & 2016 & 2022 & 2025 & 2028 & 2031 & 2034 & 2037 \\
\hline A & California & 1993 & 2002 & 2007 & 2011 & 2014 & 2017 & 2020 & 2023 & 2026 & 2029 \\
\hline $\mathrm{S}$ & Colorado & 2005 & 2008 & 2011 & 2019 & 2022 & 2025 & 2028 & 2031 & 2034 & 2037 \\
\hline M & Connecticut & 1996 & 2011 & 2015 & 2018 & 2022 & 2025 & 2028 & 2031 & 2034 & 2037 \\
\hline M & Delaware & 2002 & 2010 & 2016 & 2016 & 2022 & 2025 & 2028 & 2031 & 2034 & 2037 \\
\hline M & District of Columbia & 2006 & 2010 & 2016 & 2016 & 2022 & 2025 & 2028 & 2031 & 2034 & 2037 \\
\hline A & Florida & 1994 & 2006 & 2006 & 2013 & 2014 & 2017 & 2020 & 2023 & 2026 & 2029 \\
\hline A & Georgia & 1997 & 2004 & 2009 & 2012 & 2014 & 2017 & 2020 & 2023 & 2026 & 2029 \\
\hline $\mathrm{S}$ & Hawaii & 1998 & 2007 & 2013 & 2019 & 2022 & 2025 & 2028 & 2031 & 2034 & 2037 \\
\hline M & Idaho & 2008 & 2011 & 2014 & 2017 & 2022 & 2025 & 2028 & 2031 & 2034 & 2037 \\
\hline A & Illinois & 2003 & 2007 & 2009 & 2011 & 2014 & 2017 & 2020 & 2023 & 2026 & 2029 \\
\hline $\mathrm{S}$ & Indiana & 1996 & 2013 & 2013 & 2013 & 2022 & 2025 & 2028 & 2031 & 2034 & 2037 \\
\hline A & Iowa & 1994 & 2005 & 2008 & 2011 & 2014 & 2017 & 2020 & 2023 & 2026 & 2029 \\
\hline $\mathrm{S}$ & Kansas & 2005 & 2013 & 2019 & 2019 & 2022 & 2025 & 2028 & 2031 & 2034 & 2037 \\
\hline M & Kentucky & 2008 & 2011 & 2013 & 2017 & 2022 & 2025 & 2028 & 2031 & 2034 & 2037 \\
\hline M & Louisiana & 2005 & 2011 & 2013 & 2017 & 2022 & 2025 & 2028 & 2031 & 2034 & 2037 \\
\hline M & Maine & 1996 & 2006 & 2011 & 2017 & 2022 & 2025 & 2028 & 2031 & 2034 & 2037 \\
\hline A & Maryland & 1998 & 2006 & 2008 & 2011 & 2013 & 2017 & 2020 & 2023 & 2026 & 2029 \\
\hline A & Massachusetts & 1993 & 2002 & 2009 & 2011 & 2014 & 2017 & 2020 & 2023 & 2026 & 2029 \\
\hline M & Michigan & 2008 & 2015 & 2017 & 2017 & 2022 & 2025 & 2028 & 2031 & 2034 & 2037 \\
\hline $\mathrm{S}$ & Minnesota & 2002 & 2012 & 2012 & 2019 & 2022 & 2025 & 2028 & 2031 & 2034 & 2037 \\
\hline $\mathrm{S}$ & Mississippi & 2005 & 2013 & 2016 & 2016 & 2016 & 2025 & 2028 & 2031 & 2034 & 2037 \\
\hline S & Missouri & 2005 & 2013 & 2019 & 2019 & 2022 & 2025 & 2028 & 2031 & 2034 & 2037 \\
\hline M & Montana & 2002 & 2011 & 2016 & 2016 & 2022 & 2025 & 2028 & 2031 & 2034 & 2037 \\
\hline M & Nebraska & 2008 & 2011 & 2018 & 2018 & 2022 & 2025 & 2028 & 2031 & 2034 & 2037 \\
\hline M & Nevada & 2008 & 2011 & 2016 & 2018 & 2022 & 2025 & 2028 & 2031 & 2034 & 2037 \\
\hline A & New Hampshire & 2000 & 2003 & 2008 & 2011 & 2014 & 2017 & 2020 & 2023 & 2026 & 2029 \\
\hline M & New Jersey & 2003 & 2008 & 2013 & 2017 & 2022 & 2025 & 2028 & 2031 & 2034 & 2037 \\
\hline M & New Mexico & 2008 & 2010 & 2014 & 2018 & 2022 & 2025 & 2028 & 2031 & 2034 & 2037 \\
\hline A & New York & 1992 & 2003 & 2009 & 2012 & 2014 & 2017 & 2020 & 2023 & 2026 & 2029 \\
\hline A & North Carolina & 1997 & 2007 & 2010 & 2013 & 2014 & 2017 & 2020 & 2023 & 2026 & 2029 \\
\hline $\mathrm{S}$ & North Dakota & 2005 & 2013 & 2014 & 2014 & 2022 & 2025 & 2028 & 2031 & 2034 & 2037 \\
\hline M & Ohio & 2001 & 2011 & 2014 & 2018 & 2022 & 2025 & 2028 & 2031 & 2034 & 2037 \\
\hline $\mathrm{S}$ & Oklahoma & 2005 & 2013 & 2014 & 2019 & 2022 & 2025 & 2028 & 2031 & 2034 & 2037 \\
\hline A & Oregon & 1994 & 2002 & 2008 & 2011 & 2014 & 2017 & 2020 & 2023 & 2026 & 2029 \\
\hline M & Pennsylvania & 2008 & 2010 & 2013 & 2016 & 2022 & 2025 & 2028 & 2031 & 2034 & 2037 \\
\hline A & Rhode Island & 1998 & 2005 & 2008 & 2011 & 2014 & 2017 & 2020 & 2023 & 2026 & 2029 \\
\hline M & South Carolina & 2003 & 2011 & 2014 & 2019 & 2022 & 2025 & 2028 & 2031 & 2034 & 2037 \\
\hline S & South Dakota & 2005 & 2013 & 2019 & 2019 & 2022 & 2025 & 2028 & 2031 & 2034 & 2037 \\
\hline $\mathrm{S}$ & Tennessee & 2005 & 2013 & 2014 & 2019 & 2022 & 2025 & 2028 & 2031 & 2034 & 2037 \\
\hline M & Texas & 2007 & 2007 & 2017 & 2017 & 2022 & 2025 & 2028 & 2031 & 2034 & 2037 \\
\hline A & Utah & 1996 & 2003 & 2008 & 2011 & 2014 & 2017 & 2020 & 2023 & 2026 & 2029 \\
\hline M & Vermont & 2002 & 2007 & 2013 & 2018 & 2022 & 2025 & 2028 & 2031 & 2034 & 2037 \\
\hline M & Virginia & 2003 & 2010 & 2012 & 2017 & 2022 & 2025 & 2028 & 2031 & 2034 & 2037 \\
\hline A & Washington & 1995 & 2003 & 2006 & 2012 & 2014 & 2017 & 2020 & 2023 & 2026 & 2029 \\
\hline $\mathrm{S}$ & West Virginia & 2006 & 2013 & 2015 & 2015 & 2022 & 2025 & 2028 & 2031 & 2034 & 2037 \\
\hline M & Wisconsin & 2003 & 2014 & 2014 & 2018 & 2022 & 2025 & 2028 & 2031 & 2034 & 2037 \\
\hline $\mathrm{S}$ & Wyoming & 2005 & 2013 & 2019 & 2019 & 2022 & 2025 & 2028 & 2031 & 2034 & 2037 \\
\hline
\end{tabular}




\subsection{Code Compliance}

Promoting greater compliance with building energy codes is an important element of the BECP. The BECP conducts activities designed to increase compliance with the existing (or pending) energy code adopted by a specific state or jurisdiction. Two aspects of compliance were considered in this analysis: a) legal compliance, which is defined as meeting all of the provisions of the code; and b) compliance in energy terms, which accounts for energy savings in buildings that only partially meet the requirements of the new energy code. Therefore, compliance in energy terms is defined as "current practice" or the percentage of the code-to-code energy savings achievable from constructing to the level of the prevailing energy code rather than the prior code. Similar to the method used for adoption, reasonable alternative scenarios had to be developed to analyze the difference in compliance levels (in the first year of the code as well as subsequent years), both in the presence and absence of the BECP. These alternative scenarios were developed based on the detailed review of several key commercial energy code compliance studies (DOE 2010).

Code training and knowledge of new codes contribute significantly to the success and implementation of energy codes and savings. Without training, most builders and code officials are unlikely to change their behavior, and training activities have been critical to disseminating the necessary information. The availability of compliance software and materials also increases the success of energy codes because these tools enable builders, designers, and code inspectors to assess the compliance of construction plans with building energy codes.

Another potential reason that new code requirements disseminate, especially in the commercial sector, is professional liability. Registered design professionals may be held to the "most current" design standards even if their state or local jurisdiction is using an outdated energy code. In addition, more progressive municipalities and builders could be expected to attempt to meet at least some of the more well-publicized requirements of the new code (e.g., references to newer lighting technologies) solely based on their awareness that a new code is in effect. In the analytical framework, this effect is modeled as an increase of code compliance over time.

The following logic was applied to developing compliance assumptions for this assessment. Even with BECP in place, legal compliance with all provisions of the new code was not assumed to occur in full, at least not in the first year or two following the adoption of the new code. However, BECP assistance with training, support materials, and software tools increases the rate of compliance in energy terms (i.e., the achieved fraction of nominal energy savings for all versions of ASHRAE Standard 90.1). In the absence of the BECP, the legal compliance rates would have been lower. Similarly, rates of compliance in energy terms would be lower in the absence of BECP. Both legal compliance and compliance in energy terms would increase even without the BECP, but at a slower rate.

If no training or software tools were available to support compliance with the revised code, the initial rate of compliance in energy terms was assumed to be about 20-30\% lower than what is currently observed. This particular range was derived based on the review of recent compliance studies and the report by the American Council for an Energy-Efficient Economy (ACEEE) (Misuriello et al. 2012). This range serves as the estimate of improvement in compliance as a result of training, software support, technical assistance, and other programmatic activities. It also provided the basis for parameterizing compliance assumptions for the alternative scenario (without BECP). 
As states become more experienced with building energy codes, the percentage of achieved energy savings is expected to increase for subsequent versions of the code, even without DOE involvement in code deployment and compliance support.

This logic is reflected in Table 3.10, which shows compliance assumptions for the "with BECP" scenario for each relevant version of Standard 90.1.

Table 3.10. Compliance Assumptions for Standard 90.1, "With BECP” Scenario

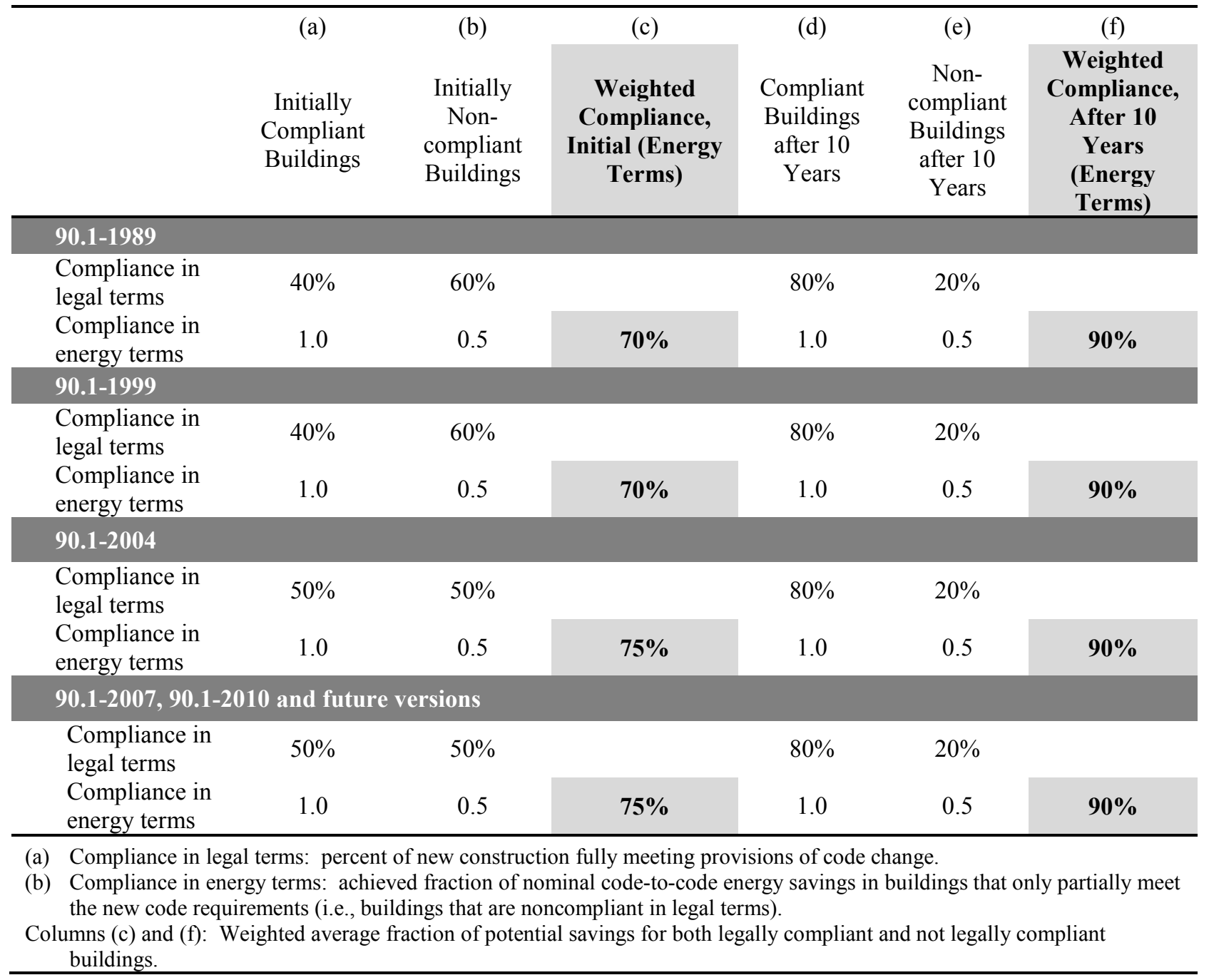

For consistency with the end-use categorization in the code-to-code savings analysis, the HVAC enduse group includes heating, cooling, fan, pump, and heat rejection, while Lighting/Other includes interior and exterior lighting, plug and process load, service hot water, refrigeration, and generators. Compliance rates presented in the table above apply to all modeled end-use groups uniformly.

Examples follow to explain the compliance assumptions in Table 3.10. As previously noted, these alternative scenarios and assumptions were developed based on the detailed review of several key commercial energy code compliance studies. The table shows two compliance rates in bold for 
Standard 90.1-1989: weighted initial compliance and weighted compliance in 10 years from code adoption. Initial weighted compliance for this code version, shown as $70 \%$, was calculated as follows:

- Given the outreach, training, information dissemination activities, and code compliance software tools developed under DOE's BECP at the time, the initial rate of compliance in legal terms was $40 \%$. This means that $40 \%$ of newly constructed buildings were assumed to fully comply with the new energy code provisions. This portion of the buildings achieved a 1.0 fraction of nominal code-to-code energy savings, i.e., the compliance in energy terms.

- The remaining portion of new commercial construction (60\%) also achieved a fraction of the nominal code-to-code savings ( 0.5 shown in column $b)$.

- Weighting the compliance in energy terms by the compliance in legal terms produced the initial weighted compliance rate of $70 \%$ with the BECP in place.

As the building community gains experience, even without formal training, technical assistance, software tools, or other BECP supporting activities, the legal compliance rate is expected to increase over time for a given code, but at a slower rate. BECP support accelerates improvement in compliance, but learning remains a significant contributing factor. These learning and spillover effects were accounted for by looking at legal compliance rates 10 years from code adoption. For Standard 90.1-1989, the weighted compliance rate in 10 years, shown as $90 \%$, was calculated as follows:

- The legal compliance increases from $40 \%$ to $80 \%$ (i.e., over 10 years), the fraction of the newly constructed buildings fully compliant with the code was assumed to double for the earlier code versions.

- Compliance in energy terms remains the same ( 0.5 fraction of the nominal code-to-code savings is achieved by the partially-compliant buildings).

- The improvement in legal compliance brings the weighted-average compliance to $90 \%$.

The compliance rate for each analysis year was calculated by using initial compliance and weighted compliance for the relevant code version as 10 -year anchor points, and interpolating the intermediate compliance rate based on how many years the adopted code version was in place.

As previously stated, for the "with BECP" scenario, the compliance rates were assumed to be uniform across the United States. For the alternative scenario (without BECP), a set of compliance lags was developed consistent with the classification of states based on code practices and adoption climate. This assumption was structured this way for several reasons:

- For establishing the impact of the Program, it is not the absolute level of compliance that drives the assessment, but rather the relative difference incompliance rates between the two compared scenarios ("with BECP" and "without BECP").

- It is very difficult to compare absolute levels of compliance across the states based on any particular definition of compliance and compatible metric. Review of the available compliance studies revealed the issues preventing meaningful cross-comparison of even the most recent results. The principal issues are differences in definitions of compliance and methods to measure/assess its level, as well as the application of different compliance metrics. 
- It was neither the intent nor the scope of this analysis to compare compliance rates at the state level. The objective was to estimate the aggregate, national energy savings induced by BECP activities. Therefore, it was more important for this analysis to focus on the difference in compliance attributable to programmatic activities, as opposed to providing a survey of compliance rates for each state across the nation.

The compliance climate is believed to be strongly correlated with the adoption rates and code practices in place. For the alternative scenario, compliance rates differ across states based on each state's adoption category. Also, the credit given to BECP for improving compliance with the older code versions is lower than the credit for improving compliance with the future code versions. The compliance difference between the "with BECP" and "without BECP" scenarios is presented in Table 3.11.

Table 3.11. Percent Point Difference between Commercial Compliance Levels "with BECP" and "without BECP"

\begin{tabular}{lcc}
\hline & $\begin{array}{c}\text { Before 90.1-2004, } \\
\text { percentage points } \\
\text { difference }\end{array}$ & $\begin{array}{c}\text { After 90.1-2004, } \\
\text { percentage points } \\
\text { difference }\end{array}$ \\
\hline Aggressive & $5 \%$ & $10 \%$ \\
Moderate & $20 \%$ & $30 \%$ \\
Slow & $10 \%$ & $20 \%$ \\
\hline
\end{tabular}

This structure of compliance assumptions is consistent with BECP focusing on the development of energy codes in the past, but switching towards improving compliance in the future.

Following the classifications described in Section 3.3.3, for the states with aggressive adoption rates, a smaller lag was assumed for adoption, and a smaller percentage point difference was assumed for compliance ( 5 and 10 percentage points, respectively). This means that under the alternative scenario (“without BECP"), for example, for Standard 90.1-1999/2001, weighted initial compliance and weighted compliance in 10 years will be 5 percentage points less than what is shown in Table 3.10. For Standard 90.1-2007, the compliance difference is 10 percentage points.

For the second group of states (with moderate adoption rates), it was assumed that without BECP's compliance-related activities, compliance would decrease by $20 \%$ from the values shown in Table 3.10 for the code versions prior to Standard 90.1-2004, and by 30\% for the consecutive code versions.

For states with slow adoption rates, the compliance rates would be 10 percentage points less than what is assumed for the code versions prior to Standard 90.1-2004 and 20 percentage points less for the code versions that follow. The initial intent was to not credit BECP with any compliance-induced savings in these states. However, American Recovery and Reinvestment Act (ARRA 2009) funding to states is believed to have led to several states adopting and implementing more recent energy codes earlier than they might have done without support. Therefore, although only a modest improvement is observed in this group of states, that improvement has occurred under targeted BECP support. 


\subsection{Estimated Benefits of the BECP Commercial Activities}

This analysis assumed that BECP commercial energy code efforts improve code-to-code energy efficiency by supporting code development, accelerate the adoption of the most recent commercial building energy codes and standards (or equivalent), and increase compliance with the code provisions. Note that energy savings achieved in California, Florida, Oregon, and Washington were totally or partially removed from the BECP benefits calculation as presented in Table $3.12 .^{8}$

Table 3.12. States Excluded from the BECP Commercial Benefits Calculation

\begin{tabular}{ll}
\hline State & \multicolumn{1}{c}{ Commercial } \\
\hline California & All years excluded \\
Florida & All years excluded \\
Oregon & Excluded 1992-2010 \\
Washington & Excluded 1992-2012 \\
\hline
\end{tabular}

The analysis period included estimation of the historical (1992-2012) and projected benefits (2013-2040) of the BECP commercial energy code activities. Projected benefits included two segments of savings as illustrated in Figure 3.2: (1) energy savings that will occur in the future, attributable to the energy code activities and construction to those codes in the past (construction occurring before 2013 but savings continuing through 2040); and (2) future savings attributable to future energy code activities and future construction (after 2013). Discussion of the estimation results follows this structure.

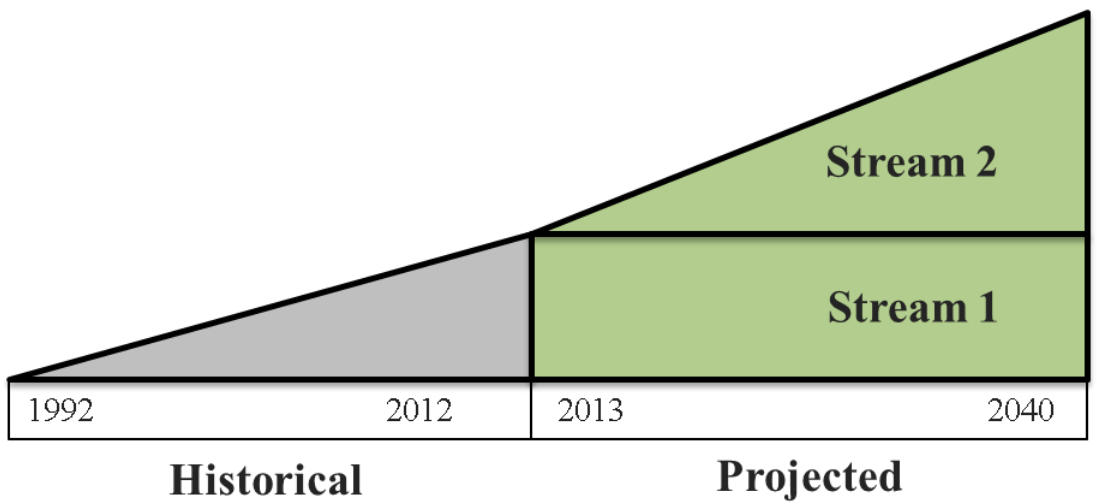

Figure 3.2. Historical and Projected Savings Streams

Following the analysis methodology used by DOE's Appliance and Equipment Standards Program, site energy savings were first converted to source terms, which includes energy used in generation, transmission, and distribution (primary energy). Energy used further "upstream" in the mining, processing, and transportation of fuels was calculated using the NIA PLUS model (Coughlin 2012) ${ }^{9}$ and added to the primary energy savings to yield full-fuel-cycle (FFC) energy savings. Emissions savings and

\footnotetext{
${ }^{8} \mathrm{CA}$ and FL have been excluded from this analysis due to their history of adopting their own advanced statespecific codes without direct assistance from BECP's tools or resources. WA and OR have been partially excluded due to their history of adopting their own state-specific codes without direct assistance from BECP's tools or resources, however, OR received state technical assistance to implement its state-specific code into COMcheck in 2010, and WA recently adopted a code based on the IECC.

${ }^{9}$ Coughlin, K., Calculation of Full Fuel Cycle Multipliers for Energy Use in Buildings. LBNL Paper, 2012.
} 
emissions monetization were also calculated using the NIA PLUS model. Detailed explanations of technical assumptions, scalars, and cost rates underlying this set of calculations are available (10 CFR 429 and 430).

The remainder of this section discusses estimated site, primary, and FFC energy savings, emissions savings, emission monetization, and consumer benefits.

BECP historical and projected energy savings (site or delivered energy) are presented in Table 3.13. For the historical portion of the Program savings, cumulative site energy savings between 1992 and 2012 totaled 1,240 trillion British thermal units (TBtu), or about 1.2 quadrillion British thermal units (quads), with the annual site energy savings being approximately $151 \mathrm{TBtu}$ at the end of 2012.

The amount of annual savings in 2012 (151 TBtu) from the pre-2012 construction continues from 2013 until 2040 because of the implicit assumption that the average expected lifetime of a commercial building exceeds the forecast horizon. This portion comprises the first stream of savings. Cumulative savings from this stream (not shown in the table) equal 4.2 quads in 2040.

Projected annual site savings from future code activities and construction equal 556 TBtu in 2040. Cumulative savings from this second savings stream equal 8.3 quads by 2040 .

When the stream of future savings from past construction and the stream of future savings from future construction are combined, the annual projected savings equal 707 TBtu at the end of 2040. Cumulative site energy savings from commercial BECP activities for the period 1992 through 2010 reach 13.8 quads. 
Table 3.13. BECP Commercial Site Energy Savings (TBtu)

\begin{tabular}{|c|c|c|c|c|c|c|}
\hline & Electricity & Natural Gas & $\begin{array}{c}\text { Total Annual } \\
\text { Savings }\end{array}$ & $\begin{array}{c}\text { Total } \\
\text { Cumulative } \\
\text { Savings } \\
\end{array}$ & & \\
\hline 1992 & 0.3 & 0.2 & 0.6 & 0.6 & & \\
\hline 1993 & 0.8 & 0.6 & 1.4 & 2.0 & & \\
\hline 1994 & 1.3 & 0.9 & 2.2 & 4.1 & & \\
\hline 1995 & 2.5 & 1.6 & 4.2 & 8.3 & & \\
\hline 1996 & 4.5 & 2.6 & 7 & 15 & & \\
\hline 1997 & 7 & 3.9 & 11 & 26 & & \\
\hline 1998 & 9 & 5 & 15 & 41 & & \\
\hline 1999 & 13 & 7 & 20 & 61 & & \\
\hline 2000 & 16 & 9 & 26 & 86 & & \\
\hline 2001 & 22 & 12 & 34 & 120 & & \\
\hline 2002 & 31 & 16 & 47 & 167 & & \\
\hline 2003 & 38 & 20 & 57 & 224 & & \\
\hline 2004 & 45 & 23 & 69 & 293 & & \\
\hline 2005 & 52 & 27 & 79 & 372 & & \\
\hline 2006 & 61 & 31 & 91 & 463 & & \\
\hline 2007 & 69 & 35 & 104 & 567 & & \\
\hline 2008 & 78 & 40 & 117 & 684 & & \\
\hline 2009 & 84 & 43 & 127 & 812 & & \\
\hline 2010 & 89 & 45 & 134 & 946 & \multicolumn{2}{|c|}{ Post 2012 construction only } \\
\hline 2011 & 94 & 49 & 143 & 1,089 & Annual & Cumulative \\
\hline 2012 & 100 & 52 & 151 & 1,240 & Site TBtu & Site TBtu \\
\hline 2013 & 108 & 56 & 164 & 1,404 & 13 & 13 \\
\hline 2014 & 114 & 60 & 175 & 1,579 & 23 & 36 \\
\hline 2015 & 122 & 65 & 187 & 1,766 & 36 & 72 \\
\hline 2016 & 138 & 74 & 211 & 1,978 & 60 & 132 \\
\hline 2017 & 151 & 82 & 232 & 2,210 & 81 & 213 \\
\hline 2018 & 163 & 89 & 253 & 2,462 & 101 & 315 \\
\hline 2019 & 183 & 100 & 283 & 2,745 & 131 & 446 \\
\hline 2020 & 200 & 110 & 310 & 3,055 & 159 & 605 \\
\hline 2021 & 218 & 120 & 338 & 3,393 & 187 & 792 \\
\hline 2022 & 235 & 129 & 364 & 3,758 & 213 & 1,005 \\
\hline 2023 & 251 & 138 & 389 & 4,146 & 237 & 1,242 \\
\hline 2024 & 266 & 146 & 413 & 4,559 & 261 & 1,504 \\
\hline 2025 & 281 & 154 & 435 & 4,994 & 283 & 1,787 \\
\hline 2026 & 294 & 161 & 455 & 5,448 & 303 & 2,090 \\
\hline 2027 & 307 & 167 & 474 & 5,923 & 323 & 2,413 \\
\hline 2028 & 320 & 174 & 495 & 6,418 & 344 & 2,757 \\
\hline 2029 & 333 & 181 & 514 & 6,931 & 363 & 3,120 \\
\hline 2030 & 345 & 187 & 533 & 7,464 & 382 & 3,501 \\
\hline 2031 & 358 & 194 & 552 & 8,016 & 400 & 3,902 \\
\hline 2032 & 370 & 200 & 571 & 8,587 & 420 & 4,321 \\
\hline 2033 & 384 & 207 & 591 & 9,178 & 440 & 4,761 \\
\hline 2034 & 395 & 213 & 609 & 9,786 & 457 & 5,218 \\
\hline 2035 & 407 & 220 & 627 & 10,414 & 476 & 5,694 \\
\hline 2036 & 420 & 226 & 646 & 11,060 & 495 & 6,189 \\
\hline 2037 & 430 & 232 & 661 & 11,721 & 510 & 6,699 \\
\hline 2038 & 440 & 237 & 677 & 12,398 & 525 & 7,225 \\
\hline 2039 & 450 & 242 & 692 & 13,090 & 541 & 7,765 \\
\hline 2040 & 460 & 248 & 707 & 13,797 & 556 & 8,321 \\
\hline
\end{tabular}


Detailed estimates for primary energy, upstream supply chain, and full-fuel-cycle are presented in Table 3.14. Primary energy savings from commercial energy code activities over the 1992-2012 period equaled 2.75 quads, with annual savings reaching 0.3 quads in 2012. The amount of annual savings from the pre-2012 construction (0.3 quads) are assumed to continue from 2013 until 2040 (projected savings, Stream 1). Cumulative savings from this stream (not in the table) equals 9.4 quads for 2013-2040.

Projected annual primary savings from future code activities (projected savings Stream 2) equal almost 1 quad in 2040. Cumulative savings from this second savings stream equal approximately 14.8 quads for 2013-2040.

When the stream of future primary savings from past construction and the stream of future primary savings from future code activities are combined (Stream $1+$ Stream 2), the annual projected savings equal 1.3 quads by 2040. Cumulative projected savings from commercial BECP activities between 2013 and 2040 exceed 24.2 quads by 2040 .

Combining 2.75 quads of cumulative historical savings with 24.2 quads of cumulative projected savings brings the total BECP primary energy savings from commercial code activities to almost 27 quads for 1992-2040.

FFC energy savings from commercial energy code activities over the 1992-2012 period equaled 2.8 quads, with annual savings reaching 346 TBtu in 2012. The amount of annual savings from the pre2012 construction (346 TBtu) are assumed to continue from 2013 until 2040 (projected savings, Stream 1). Cumulative savings from this stream (not shown in the table) equal almost 9.7 quads for 2013-2040.

Projected annual FFC energy savings from future code activities (projected savings Stream 2) equal almost 1 quad in 2040. Cumulative savings from this second savings stream equal 15.3 quads for 20132040 .

When the stream of future savings from past construction and the stream of future savings from future code activities are combined (Stream $1+$ Stream 2), the annual projected savings exceed 1.3 quads by 2040. Cumulative projected savings from commercial BECP activities between 2013 and 2040 equal 25 quads by 2040 .

Combining almost 2.8 quads of cumulative historical savings with 25 quads of cumulative projected FFC savings brings the total BECP savings from commercial code activities to 27.8 quads for $1992-2040$.

Historical and projected site energy savings were then used to calculate total commercial energy cost savings. For 1992-2012 savings, EIA historical electricity and natural gas prices for the commercial sector ${ }^{10}$ were converted to 2012 dollars based on the gross domestic product (GDP) chain-type price index ${ }^{11}$ to calculate the annual and cumulative cost savings. Annual cost savings reached $\$ 3.3$ billion in 2012. Cumulative savings between 1992 and 2012 equaled \$29 billion.

${ }^{10}$ U.S. Energy Information Administration. Form EIA-826 Database Monthly Electric Utility Sales and Revenue Data (EIA-826 Sales and Revenue Spreadsheets). Select Table: Sales and Revenue Data by State, Monthly Back to 1990 (Form EIA-826). (Last accessed June 25, 2013.) <www.eia.gov/electricity/data.cfm\#sales >. U.S. Energy Information Administration. Average Price of Natural Gas Sold to Commercial Consumers - by State. 2012. (Last accessed June 26, 2013.) < www.eia.gov/oil_gas/natural_gas/data publications/natural gas monthly/ngm.html>

${ }^{11}$ Federal Reserve Economic Data, Gross Domestic Product: Chain-type Price Index (GDPCTPI), Index 2005=100, Annual, Seasonally Adjusted. Economic Research Division, Federal Reserve Bank of St. Louis, http://research.stlouisfed.org/fred2 
Table 3.14. BECP Commercial Primary and Full-Fuel-Cycle Energy Savings (TBtu)

\begin{tabular}{|c|c|c|c|c|c|c|}
\hline & Primary & $\begin{array}{c}\text { Upstream } \\
\text { Supply Chain }\end{array}$ & FFC, Annual & $\begin{array}{c}\text { FFC, } \\
\text { Cumulative }\end{array}$ & & \\
\hline 1992 & 1.2 & 0.0 & 1.2 & 1.2 & & \\
\hline 1993 & 2.9 & 0.1 & 3.0 & 4.3 & & \\
\hline 1994 & 4.5 & 0.1 & 4.7 & 9 & & \\
\hline 1995 & 9 & 0.3 & 9 & 18 & & \\
\hline 1996 & 15 & 0.5 & 16 & 34 & & \\
\hline 1997 & 23 & 0.7 & 24 & 58 & & \\
\hline 1998 & 32 & 1.0 & 33 & 91 & & \\
\hline 1999 & 43 & 1.3 & 45 & 135 & & \\
\hline 2000 & 56 & 1.7 & 57 & 193 & & \\
\hline 2001 & 73 & 2.2 & 76 & 268 & & \\
\hline 2002 & 104 & 3.0 & 107 & 375 & & \\
\hline 2003 & 127 & 3.7 & 131 & 506 & & \\
\hline 2004 & 152 & 4.4 & 157 & 663 & & \\
\hline 2005 & 176 & 5.0 & 181 & 843 & & \\
\hline 2006 & 203 & 5.8 & 209 & 1,053 & & \\
\hline 2007 & 232 & 6.6 & 238 & 1,291 & & \\
\hline 2008 & 261 & 7.5 & 269 & 1,560 & & \\
\hline 2009 & 283 & 8.1 & 291 & 1,851 & & \\
\hline 2010 & 299 & 8.6 & 307 & 2,158 & \multicolumn{2}{|c|}{ Post 2012 construction } \\
\hline 2011 & 318 & 9.0 & 327 & 2,485 & FFC, & FFC, \\
\hline 2012 & 336 & 9.8 & 346 & 2,831 & Annual & Cumulative \\
\hline 2013 & 364 & 10 & 374 & 3,205 & 29 & 29 \\
\hline 2014 & 387 & 11 & 398 & 3,603 & 52 & 80 \\
\hline 2015 & 414 & 12 & 425 & 4,028 & 80 & 160 \\
\hline 2016 & 466 & 13 & 480 & 4,508 & 134 & 294 \\
\hline 2017 & 511 & 15 & 526 & 5,034 & 180 & 474 \\
\hline 2018 & 555 & 16 & 571 & 5,605 & 225 & 699 \\
\hline 2019 & 621 & 18 & 638 & 6,243 & 293 & 992 \\
\hline 2020 & 681 & 20 & 700 & 6,944 & 355 & 1,347 \\
\hline 2021 & 692 & 21 & 713 & 7,657 & 367 & 1,714 \\
\hline 2022 & 746 & 23 & 768 & 8,425 & 423 & 2,136 \\
\hline 2023 & 795 & 24 & 820 & 9,244 & 474 & 2,610 \\
\hline 2024 & 845 & 25 & 871 & 10,115 & 525 & 3,135 \\
\hline 2025 & 891 & 27 & 917 & 11,032 & 571 & 3,706 \\
\hline 2026 & 859 & 28 & 887 & 11,919 & 541 & 4,248 \\
\hline 2027 & 897 & 29 & 926 & 12,845 & 580 & 4,828 \\
\hline 2028 & 936 & 30 & 966 & 13,811 & 620 & 5,448 \\
\hline 2029 & 972 & 31 & 1,003 & 14,815 & 658 & 6,106 \\
\hline 2030 & 1,008 & 32 & 1,041 & 15,856 & 695 & 6,801 \\
\hline 2031 & 1,008 & 34 & 1,042 & 16,898 & 696 & 7,497 \\
\hline 2032 & 1,044 & 35 & 1,079 & 17,977 & 733 & 8,230 \\
\hline 2033 & 1,081 & 36 & 1,117 & 19,094 & 771 & 9,001 \\
\hline 2034 & 1,114 & 37 & 1,151 & 20,244 & 805 & 9,806 \\
\hline 2035 & 1,147 & 38 & 1,185 & 21,430 & 840 & 10,646 \\
\hline 2036 & 1,183 & 39 & 1,222 & 22,651 & 876 & 11,522 \\
\hline 2037 & 1,210 & 40 & 1,251 & 23,902 & 905 & 12,427 \\
\hline 2038 & 1,238 & 41 & 1,279 & 25,181 & 934 & 13,360 \\
\hline 2039 & 1,266 & 42 & 1,308 & 26,490 & 963 & 14,323 \\
\hline 2040 & 1,294 & 43 & 1,337 & 27,827 & 991 & 15,314 \\
\hline
\end{tabular}


The NIA PLUS model was used to calculate the net present value (NPV) of projected future cost savings. AEO 2013 reference case prices were converted to 2012 dollars and a 7\% discount rate was applied. The NPV of annual projected savings in 2040 for Stream 1 equals $\$ 0.6$ billion. The NPV of cumulative cost savings for Stream 1 exceeds $\$ 44$ billion. The NPV of annual projected savings in 2040 for Stream 2 equals $\$ 2.3$ billion. The NPV of cumulative cost savings for Stream 2 equals $\$ 61.7$ billion. Combined, the NPV of projected future energy cost savings equals approximately $\$ 106$ billion and the grand total from 1992-2040 is $\$ 135$ billion. A summary of the cost savings along with the FFC energy savings is presented in Table 3.15.

Table 3.15. Summary of Energy and Cost Savings from the BECP Commercial Energy Code Activities

\begin{tabular}{lcccc}
\hline & $\begin{array}{c}\text { Site Energy } \\
\text { Savings, } \\
\text { TBtu }\end{array}$ & $\begin{array}{c}\text { Primary Energy } \\
\text { Savings, } \\
\text { TBtu }\end{array}$ & $\begin{array}{c}\text { FFC Energy } \\
\text { Savings, } \\
\text { TBtu }\end{array}$ & $\begin{array}{c}\text { Energy Cost } \\
\text { Savings NPV, } \\
\text { billion 2012\$ }\end{array}$ \\
\hline Historical & 151 & & & \\
$\quad$ Annual in 2012 & 336 & 346 & 3.31 \\
$\quad$ Cumulative 1992-2012 & 1,240 & 2,751 & 2,831 & 29.01 \\
$\begin{array}{l}\text { Projected, Stream 1 } \\
\quad \text { Annual in 2040 }\end{array}$ & 151 & & & \\
$\quad$ Cumulative 2013-2040 & 4,236 & 336 & 346 & 0.63 \\
Projected, Stream 2 & & 9,408 & 9,682 & 44.33 \\
$\quad$ Annual in 2040 & 556 & & & \\
$\quad$ Cumulative 2013-2040 & 8,321 & 14,818 & 15,314 & 6.30 \\
BECP Total & & & & \\
$\quad$ Annual in 2040 & 707 & 1,294 & 1,337 & 2.93 \\
$\quad$ Cumulative 1992-2040 & 13,797 & 26,977 & 27,827 & 135.1 \\
\hline
\end{tabular}

Emissions savings were estimated for carbon dioxide $\left(\mathrm{CO}_{2}\right)$, nitrogen oxide $\left(\mathrm{NO}_{\mathrm{x}}\right)$, mercury $(\mathrm{Hg})$, nitrous oxide $\left(\mathrm{N}_{2} \mathrm{O}\right)$, methane $\left(\mathrm{CH}_{4}\right)$, and sulfur dioxide $\left(\mathrm{SO}_{2}\right)$. Detailed annual results for the emissions savings are included in Table 3.16. A summary of historical and projected emissions savings is presented in Table 3.17 .

Cumulative emissions reductions between 1992 and 2040 include more than 2.1 billion metric tons (Mt) of $\mathrm{CO}_{2}, 2.7$ million tons of $\mathrm{SO}_{2}, 2.7$ million tons of $\mathrm{NO}_{\mathrm{x}}$, and 4.8 tons of $\mathrm{Hg}$.

The value of the FFC $\mathrm{CO}_{2}$ emission reductions is $\$ 1.2$ to $\$ 4.0$ billion based on 2013 domestic social carbon values and a 5\% discount rate, or about $\$ 17$ billion based on 2013 global social cost of carbon (SCC), while $\mathrm{NO}_{\mathrm{x}}$ savings contribute almost another $\$ 0.7$ billion (at $\$ 468$ per ton in $2012 \$$ ). Energy cost savings presented in Table 3.15, combined with monetized emission savings presented in Table 3.18, capture consumer benefits to the nation from the commercial BECP activities. Combined consumer benefits from commercial BECP activities are shown in Table 3.19. Depending on the price of $\mathrm{CO}_{2}$ and $\mathrm{NO}_{\mathrm{x}}$, the NPV of overall consumer benefits can range between $\$ 153$ and $\$ 359$ billion (2012\$). Out of that total, the energy cost savings constitute $\$ 135$ billion (2012\$). 
Table 3.16. Annual Emissions Savings from the BECP Commercial Activities, Full-Fuel-Cycle

\begin{tabular}{|c|c|c|c|c|c|c|c|c|}
\hline & $\begin{array}{l}\mathrm{CO}_{2} \\
\mathrm{mmt}\end{array}$ & $\begin{array}{c}\mathrm{NO}_{\mathrm{x}} \\
k t\end{array}$ & $\begin{array}{l}\mathrm{Hg} \\
\text { ton }\end{array}$ & $\begin{array}{c}\mathrm{N}_{2} \mathrm{O} \\
k t\end{array}$ & $\begin{array}{c}\mathrm{N}_{2} \mathrm{O} \\
m m t \mathrm{CO}_{2} e q \\
\end{array}$ & $\begin{array}{c}\mathrm{CH}_{4} \\
k t\end{array}$ & $\begin{array}{c}\mathrm{CH}_{4} \\
\mathrm{mmt} \mathrm{CO}_{2} e q \\
\end{array}$ & $\begin{array}{c}\mathrm{SO}_{2} \\
k t\end{array}$ \\
\hline 1992 & 0.1 & 0.2 & 0.00 & 0.0 & 0.00 & 0.4 & 0.0 & 0.1 \\
\hline 1993 & 0.2 & 0.5 & 0.00 & 0.0 & 0.00 & 1.0 & 0.0 & 0.3 \\
\hline 1994 & 0.3 & 0.7 & 0.00 & 0.0 & 0.00 & 1.5 & 0.0 & 0.4 \\
\hline 1995 & 0.7 & 1.5 & 0.00 & 0.0 & 0.00 & 2.9 & 0.1 & 0.9 \\
\hline 1996 & 1.1 & 2.5 & 0.00 & 0.0 & 0.00 & 4.9 & 0.1 & 1.5 \\
\hline 1997 & 1.8 & 3.9 & 0.00 & 0.0 & 0.01 & 7.5 & 0.2 & 2.3 \\
\hline 1998 & 2.4 & 5.2 & 0.01 & 0.0 & 0.01 & 10 & 0.3 & 3.1 \\
\hline 1999 & 3.2 & 7.1 & 0.01 & 0.0 & 0.01 & 14 & 0.3 & 4.3 \\
\hline 2000 & 4.2 & 9.1 & 0.01 & 0.0 & 0.01 & 18 & 0.4 & 5.5 \\
\hline 2001 & 5.5 & 12 & 0.01 & 0.1 & 0.02 & 23 & 0.6 & 7.3 \\
\hline 2002 & 7.8 & 17 & 0.02 & 0.1 & 0.03 & 33 & 0.8 & 10 \\
\hline 2003 & 10 & 21 & 0.02 & 0.1 & 0.03 & 40 & 1.0 & 13 \\
\hline 2004 & 11 & 25 & 0.03 & 0.1 & 0.04 & 47 & 1.2 & 15 \\
\hline 2005 & 13 & 29 & 0.03 & 0.2 & 0.05 & 55 & 1.4 & 18 \\
\hline 2006 & 15 & 33 & 0.04 & 0.2 & 0.05 & 63 & 1.6 & 21 \\
\hline 2007 & 17 & 38 & 0.04 & 0.2 & 0.06 & 72 & 1.8 & 23 \\
\hline 2008 & 20 & 43 & 0.05 & 0.2 & 0.07 & 81 & 2.0 & 26 \\
\hline 2009 & 21 & 47 & 0.05 & 0.2 & 0.07 & 88 & 2.2 & 29 \\
\hline 2010 & 22 & 49 & 0.05 & 0.3 & 0.08 & 93 & 2.3 & 30 \\
\hline 2011 & 24 & 52 & 0.06 & 0.3 & 0.08 & 98 & 2.4 & 32 \\
\hline 2012 & 25 & 56 & 0.06 & 0.3 & 0.08 & 104 & 2.6 & 34 \\
\hline 2013 & 27 & 60 & 0.06 & 0.3 & 0.09 & 109 & 2.7 & 37 \\
\hline 2014 & 29 & 63 & 0.07 & 0.3 & 0.09 & 116 & 2.9 & 39 \\
\hline 2015 & 31 & 67 & 0.07 & 0.3 & 0.09 & 126 & 3.1 & 41 \\
\hline 2016 & 35 & 76 & 0.08 & 0.3 & 0.10 & 141 & 3.5 & 46 \\
\hline 2017 & 38 & 83 & 0.09 & 0.4 & 0.11 & 154 & 3.9 & 51 \\
\hline 2018 & 41 & 90 & 0.09 & 0.4 & 0.12 & 167 & 4.2 & 55 \\
\hline 2019 & 46 & 101 & 0.10 & 0.5 & 0.14 & 186 & 4.7 & 61 \\
\hline 2020 & 51 & 110 & 0.11 & 0.5 & 0.15 & 203 & 5.1 & 67 \\
\hline 2021 & 49 & 45 & 0.11 & 0.6 & 0.16 & 220 & 5.5 & 210 \\
\hline 2022 & 53 & 48 & 0.11 & 0.6 & 0.18 & 235 & 5.9 & 226 \\
\hline 2023 & 56 & 52 & 0.12 & 0.6 & 0.19 & 250 & 6.2 & 241 \\
\hline 2024 & 60 & 55 & 0.13 & 0.7 & 0.20 & 264 & 6.6 & 256 \\
\hline 2025 & 63 & 57 & 0.14 & 0.7 & 0.22 & 277 & 6.9 & 270 \\
\hline 2026 & 66 & 66 & 0.13 & 0.8 & 0.23 & 290 & 7.2 & 51 \\
\hline 2027 & 69 & 69 & 0.14 & 0.8 & 0.23 & 302 & 7.6 & 53 \\
\hline 2028 & 72 & 72 & 0.15 & 0.8 & 0.24 & 316 & 7.9 & 56 \\
\hline 2029 & 75 & 75 & 0.15 & 0.8 & 0.25 & 328 & 8.2 & 58 \\
\hline 2030 & 78 & 78 & 0.16 & 0.9 & 0.26 & 341 & 8.5 & 60 \\
\hline 2031 & 86 & 85 & 0.20 & 0.9 & 0.27 & 353 & 8.8 & 51 \\
\hline 2032 & 89 & 88 & 0.20 & 0.9 & 0.28 & 366 & 9.2 & 53 \\
\hline 2033 & 93 & 92 & 0.21 & 1.0 & 0.29 & 380 & 9.5 & 55 \\
\hline 2034 & 95 & 94 & 0.22 & 1.0 & 0.30 & 391 & 9.8 & 56 \\
\hline 2035 & 98 & 97 & 0.22 & 1.0 & 0.31 & 402 & 10.0 & 58 \\
\hline 2036 & 101 & 100 & 0.23 & 1.1 & 0.32 & 414 & 10.4 & 60 \\
\hline 2037 & 104 & 102 & 0.24 & 1.1 & 0.32 & 424 & 10.6 & 61 \\
\hline 2038 & 106 & 105 & 0.24 & 1.1 & 0.33 & 434 & 10.9 & 63 \\
\hline 2039 & 108 & 107 & 0.25 & 1.1 & 0.34 & 445 & 11.1 & 64 \\
\hline 2040 & 111 & 109 & 0.25 & 1.2 & 0.34 & 455 & 11.4 & 65 \\
\hline Total & 2,138 & 2,699 & 4.75 & 23 & 6.88 & 8,945 & 224 & 2,742 \\
\hline
\end{tabular}


Table 3.17. Summary of Emissions Savings from the BECP Commercial Energy Code Activities

\begin{tabular}{|c|c|c|c|c|c|c|c|c|c|}
\hline & & $\begin{array}{c}\mathrm{CO}_{2} \\
m m t\end{array}$ & $\begin{array}{c}\text { NO }_{\mathrm{x}} \\
k t\end{array}$ & $\begin{array}{c}\mathrm{Hg} \\
\text { ton }\end{array}$ & $\begin{array}{c}\mathrm{N}_{2} \mathrm{O} \\
k t\end{array}$ & $\begin{array}{c}\mathrm{N}_{2} \mathrm{O} \\
m m t \mathrm{CO}_{2} e q\end{array}$ & $\begin{array}{c}\mathrm{CH}_{4} \\
k t\end{array}$ & $\begin{array}{c}\mathrm{CH}_{4} \\
m m t \mathrm{CO}_{2} e q\end{array}$ & $\begin{array}{c}\mathrm{SO}_{2} \\
k t\end{array}$ \\
\hline \multicolumn{10}{|l|}{ Historical } \\
\hline & Annual in 2012 & 25 & 56 & 0.1 & 0.3 & 0.1 & 104 & 2.6 & 34 \\
\hline & Cumulative 1992-2012 & 206 & 453 & 0.5 & 2.4 & 0.7 & 857 & 21 & 277 \\
\hline \multicolumn{10}{|c|}{ Projected, Stream 1} \\
\hline & Annual in 2040 & 25 & 56 & 0.1 & 0.3 & 0.1 & 104 & 2.6 & 34 \\
\hline & Cumulative 2013-2040 & 706 & 1,555 & 1.6 & 7.6 & 2.3 & 2,911 & 73 & 946 \\
\hline \multicolumn{10}{|c|}{ Projected, Stream 2} \\
\hline & Annual in 2040 & 86 & 54 & 0.2 & 0.9 & 0.3 & 351 & 8.8 & 32 \\
\hline & Cumulative 2013-2040 & 1,226 & 691 & 2.6 & 13.1 & 3.9 & 5,176 & 129 & 1,519 \\
\hline \multicolumn{10}{|l|}{ BECP Total } \\
\hline & Annual in 2040 & 111 & 109 & 0.3 & 1.2 & 0.3 & 455 & 11 & 65 \\
\hline & Cumulative 1992-2040 & 2,138 & 2,699 & 4.8 & 23.1 & 6.9 & 8,945 & 224 & 2,742 \\
\hline
\end{tabular}

Table 3.18. National Cumulative Benefits of the BECP Commercial Activities, 1992-2040

\begin{tabular}{|c|c|c|}
\hline \multicolumn{3}{|l|}{ Energy Savings } \\
\hline Primary & quads & 26.98 \\
\hline Upstream & quads & 0.85 \\
\hline Full-Fuel-Cycle (total) & quads & 27.83 \\
\hline \multicolumn{3}{|l|}{ Economic Impacts } \\
\hline Historical Energy Cost Savings & billion $2012 \$$ & 29.01 \\
\hline Projected Energy Cost Savings & billion $2012 \$$ & 106.05 \\
\hline Total Energy Cost Savings & billion $2012 \$$ & 135.07 \\
\hline \multicolumn{3}{|l|}{ Emissions Savings (physical) } \\
\hline \multicolumn{3}{|l|}{ Primary } \\
\hline $\mathrm{CO}_{2}$ & $\mathrm{mmt}$ & 2,030 \\
\hline $\mathrm{NO}_{\mathrm{x}}$ & $\mathrm{kt}$ & 1,209 \\
\hline $\mathrm{Hg}$ & ton & 4.7 \\
\hline $\mathrm{N}_{2} \mathrm{O}$ & $\mathrm{kt}$ & 22.3 \\
\hline $\mathrm{N}_{2} \mathrm{O}$ & $\mathrm{mmt} \mathrm{CO}_{2} \mathrm{eq}$ & 6.6 \\
\hline $\mathrm{CH}_{4}$ & $\mathrm{kt}$ & 156 \\
\hline $\mathrm{CH}_{4}$ & $\mathrm{mmt} \mathrm{CO}_{2} \mathrm{eq}$ & 3.9 \\
\hline $\mathrm{SO}_{2}$ & $\mathrm{kt}$ & 2,723 \\
\hline \multicolumn{3}{|l|}{ Upstream } \\
\hline $\mathrm{CO}_{2}$ & $\mathrm{mmt}$ & 108 \\
\hline $\mathrm{NO}_{\mathrm{x}}$ & $\mathrm{kt}$ & 1,489 \\
\hline $\mathrm{Hg}$ & ton & 0.1 \\
\hline $\mathrm{N}_{2} \mathrm{O}$ & $\mathrm{kt}$ & 0.8 \\
\hline $\mathrm{N}_{2} \mathrm{O}$ & $\mathrm{mmt} \mathrm{CO}{ }_{2} \mathrm{eq}$ & 0.2 \\
\hline $\mathrm{CH}_{4}$ & $\mathrm{kt}$ & 8,788 \\
\hline $\mathrm{CH}_{4}$ & $\mathrm{mmt} \mathrm{CO} \mathrm{Cq}_{2}$ & 220 \\
\hline $\mathrm{SO}_{2}$ & $\mathrm{kt}$ & 19 \\
\hline \multicolumn{3}{|l|}{ Full-Fuel-Cycle (total) } \\
\hline $\mathrm{CO}_{2}$ & $\mathrm{mmt}$ & 2,138 \\
\hline $\mathrm{NO}_{\mathrm{x}}$ & $\mathrm{kt}$ & 2,699 \\
\hline $\mathrm{Hg}$ & ton & 4.8 \\
\hline $\mathrm{N}_{2} \mathrm{O}$ & $\mathrm{kt}$ & 23.1 \\
\hline $\mathrm{N}_{2} \mathrm{O}$ & $\mathrm{mmt} \mathrm{CO} \mathrm{Cq}_{2}$ & 6.9 \\
\hline $\mathrm{CH}_{4}$ & $\mathrm{kt}$ & 8,945 \\
\hline $\mathrm{CH}_{4}$ & $\mathrm{mmt} \mathrm{CO}_{2} \mathrm{eq}$ & 224 \\
\hline $\mathrm{SO}_{2}$ & $\mathrm{kt}$ & 2,742 \\
\hline
\end{tabular}


Table 3.18. (contd)

\begin{tabular}{|c|c|c|}
\hline \multicolumn{3}{|l|}{ Emissions Savings (monetized) } \\
\hline \multicolumn{3}{|l|}{ Primary } \\
\hline \multicolumn{3}{|l|}{$\mathrm{CO}_{2}$ (global) } \\
\hline $5 \%$ discount rate, average & billion $2012 \$$ & 16.5 \\
\hline $3 \%$ discount rate, average & billion $2012 \$$ & 67.7 \\
\hline $2.5 \%$ discount rate, average & billion $2012 \$$ & 106.9 \\
\hline $3 \%$ discount rate, 95 th $\%$ ile & billion $2012 \$$ & 205.9 \\
\hline \multicolumn{3}{|l|}{$\mathrm{CO}_{2}$ (domestic) } \\
\hline $5 \%$ discount rate, average & billion $2012 \$$ & 1.2 to 3.8 \\
\hline $3 \%$ discount rate, average & billion $2012 \$$ & 4.7 to 15.6 \\
\hline $2.5 \%$ discount rate, average & billion $2012 \$$ & 7.5 to 24.6 \\
\hline $3 \%$ discount rate, 95 th $\%$ ile & billion $2012 \$$ & 14.4 to 47.4 \\
\hline \multicolumn{3}{|l|}{$\mathrm{NO}_{\mathrm{x}}(7 \%$ discount rate $)$} \\
\hline At $4682012 \$ /$ ton & billion $2012 \$$ & 0.4 \\
\hline At $2,6392012 \$ /$ ton & billion $2012 \$$ & 2.1 \\
\hline At $4,8092012 \$ /$ ton & billion $2012 \$$ & 3.8 \\
\hline \multicolumn{3}{|l|}{ Upstream } \\
\hline \multicolumn{3}{|l|}{$\mathrm{CO}_{2}$ (global) } \\
\hline $5 \%$ discount rate, average & billion $2012 \$$ & 0.9 \\
\hline $3 \%$ discount rate, average & billion $2012 \$$ & 3.6 \\
\hline $2.5 \%$ discount rate, average & billion $2012 \$$ & 5.7 \\
\hline $3 \%$ discount rate, 95 th $\%$ ile & billion $2012 \$$ & 11.0 \\
\hline \multicolumn{3}{|l|}{$\mathrm{CO}_{2}$ (domestic) } \\
\hline $5 \%$ discount rate, average & billion $2012 \$$ & 0.1 to 0.2 \\
\hline $3 \%$ discount rate, average & billion $2012 \$$ & 0.3 to 0.8 \\
\hline $2.5 \%$ discount rate, average & billion $2012 \$$ & 0.4 to 1.3 \\
\hline $3 \%$ discount rate, 95 th $\%$ ile & billion $2012 \$$ & 0.8 to 2.5 \\
\hline \multicolumn{3}{|l|}{$\mathrm{NO}_{\mathrm{x}}(7 \%$ discount rate $)$} \\
\hline At $4682012 \$ /$ ton & billion $2012 \$$ & 0.3 \\
\hline At $2,6392012 \$ /$ ton & billion $2012 \$$ & 1.7 \\
\hline At $4,8092012 \$ /$ ton & billion $2012 \$$ & 3.1 \\
\hline \multicolumn{3}{|l|}{ Full-Fuel-Cycle (total) } \\
\hline \multicolumn{3}{|l|}{$\mathrm{CO}_{2}$ (global) } \\
\hline $5 \%$ discount rate, average & billion $2012 \$$ & 17.3 \\
\hline $3 \%$ discount rate, average & billion $2012 \$$ & 71.3 \\
\hline $2.5 \%$ discount rate, average & billion $2012 \$$ & 112.6 \\
\hline $3 \%$ discount rate, 95 th $\%$ ile & billion $2012 \$$ & 216.8 \\
\hline \multicolumn{3}{|l|}{$\mathrm{CO}_{2}$ (domestic) } \\
\hline $5 \%$ discount rate, average & billion $2012 \$$ & 1.2 to 4 \\
\hline $3 \%$ discount rate, average & billion $2012 \$$ & 5 to 16.4 \\
\hline $2.5 \%$ discount rate, average & billion $2012 \$$ & 7.9 to 25.9 \\
\hline $3 \%$ discount rate, 95 th $\%$ ile & billion $2012 \$$ & 15.2 to 49.9 \\
\hline \multicolumn{3}{|l|}{$\mathrm{NO}_{\mathrm{x}}(7 \%$ discount rate $)$} \\
\hline At $4682012 \$ /$ ton & billion $2012 \$$ & 0.7 \\
\hline At $2,6392012 \$ /$ ton & billion $2012 \$$ & 3.8 \\
\hline At $4,8092012 \$ /$ ton & billion $2012 \$$ & 6.9 \\
\hline
\end{tabular}


Table 3.19. Cumulative Consumer Benefits from BECP Commercial Codes Activities

\begin{tabular}{lll}
\hline NPV & & \\
$\quad$ Consumer Energy Cost Savings & billion 2012\$ & 135 \\
Consumer \& Emissions Value & & \\
Consumers $+\mathrm{CO}_{2}(1 \mathrm{st})+\mathrm{NO}_{\mathrm{x}}(\mathrm{Low})$ & billion 2012\$ & 153 \\
Consumers $+\mathrm{CO}_{2}(2 \mathrm{nd})+\mathrm{NO}_{\mathrm{x}}(\mathrm{Med})$ & billion 2012\$ & 210 \\
Consumers $+\mathrm{CO}_{2}(3 \mathrm{rd})+\mathrm{NO}_{\mathrm{x}}(\mathrm{Med})$ & billion 2012\$ & 251 \\
Consumers $+\mathrm{CO}_{2}(4 \mathrm{th})+\mathrm{NO}_{\mathrm{x}}(\mathrm{High})$ & billion 2012\$ & 359 \\
\hline
\end{tabular}

Each of the consumer and emissions value estimates above represents a combination of consumer energy cost savings and corresponding scenarios for monetized reduction of $\mathrm{CO}_{2}$ and $\mathrm{NO}_{\mathrm{x}}$. For example, Consumers $+\mathrm{CO}_{2}(1 \mathrm{st})+\mathrm{NO}_{\mathrm{x}}$ (Low) means that savings from the first scenario of $\mathrm{CO}_{2}(5 \%$ discount rate, average, global SCC) were combined with savings from the low $\mathrm{NO}_{\mathrm{x}}$ cost scenario (at $\$ 468$ per ton in $2012 \$$ ) and added to the consumer energy cost savings. 


\subsection{Residential Assumptions and Estimated Results}

This section discusses how the energy savings attributable to different residential energy code versions were compared; how the applicable residential floor space subject to the code was determined; and what adoption and compliance assumptions were used in the analysis.

\subsection{Residential Energy Code Performance (Code-to-Code Savings)}

Required by the Energy Conservation and Production Act (ECPA, Public Law 94-385), as modified by the Energy Policy Act of 1992 (EPAct 1992), DOE must determine whether the most recent edition of a national model code (e.g., IECC for residential buildings) will save energy when compared to its prior edition. This "determination" process occurs with every new version of the IECC released. Results of the determination analysis are published in the Federal Register. If the analysis shows that the revised code is more energy efficient than the earlier code, each state is required to certify that it has reviewed its residential building energy code regarding energy efficiency and made a decision as to whether it is appropriate for that state to update its residential building code at or above the revised code. Results of the Determination provide the foundation for estimating energy savings in this report.

A methodology has been established for evaluating the energy performance of the newest residential energy codes by comparing with its predecessors (Taylor et al. 2012). PNNL evaluates the residential codes as a whole to establish expected energy savings by simulating the effects of the code change(s) on typical, new residential buildings, assuming both code provisions are implemented fully and correctly. Code-to-code energy savings used in the residential benefits estimation are results of this analysis aggregated to the state level.

The most recent analysis ${ }^{12}$ evaluated the energy savings and economic impacts of the 2009 and 2012 IECC compared to the 2006 IECC, as well as the 2012 IECC compared to the 2009 IECC. Energy usage was modeled using DOE's EnergyPlus software for two residential building prototypes:

1. Single-Family: A two-story detached home with a $30-\mathrm{ft}$ by $40-\mathrm{ft}$ rectangular shape, $2,400 \mathrm{ft}^{2}$ of conditioned floor area, and a 15\% window-to-floor ratio, with the window area equally distributed to the four cardinal directions.

2. Multifamily: A three-story building with 18 apartment units (6 units per floor), each with a conditioned floor area of $1,200 \mathrm{ft}^{2}$ and a window-to-floor ratio of approximately $10 \%$, with the window area equally distributed on all sides of the building.

The prototypes used in the simulations were intended to represent, respectively, a typical new one- or two-family home or townhouse, and a low-rise multifamily building, such as an apartment, cooperative, or condominium. Four foundation types were examined for each prototype building: vented crawlspace, slab-on-grade, heated basement with wall insulation, and unheated basement with insulation in the floor above the basement. All buildings were evaluated with central air conditioning and each of four heating system types: gas furnace, oil furnace, heat pump, and electric furnace.

\footnotetext{
${ }^{12}$ Detailed characteristics of the prototypes used in DOE's analyses and detailed weighting factor information are discussed in Taylor et al. (2012).
} 
To facilitate climate-specific energy estimates, PNNL used a set of weather locations that resulted in broad climate coverage at both the climate zone and state level. One weather location per climate zone in each state was selected, including all unique combinations of the zone (temperature-oriented zone designation in the IECC), moisture regime (moist, dry, marine), and warm-humid designation (equivalent to ASHRAE's definition of warm-humid climates). This resulted in a set of 119 weather locations, which was then used to simulate the energy performance of each building energy model.

Energy simulation results for a given location were first weighted across the foundation type, system type, and building type variables, using foundation shares, heating system shares, and new housing starts data, respectively. The weighted, location-specific results were then aggregated to the state level using new construction starts data.

State-level estimates of the energy code performance for the 2006, 2009, and 2012 versions of the IECC were obtained for three fuels (electricity, natural gas, and heating oil) and four groups of end uses (heating, cooling, water heating, and lighting/other). These estimates grouped by fuel type are presented in Table 4.1 in terms of site energy use per household.

The analyzed IECC versions contain provisions that overlap with federal appliance efficiency standards for heating, air conditioning, water heating, and lighting equipment. Because the mandated efficiency will be enforced as a manufacturing standard regardless of whether it is stipulated in the IECC, the inclusion of these requirements in the IECC has no separate energy impact. Therefore, code-to-code savings used in the BECP residential benefits analysis explicitly excluded savings induced by the federal equipment efficiency standards for heating, air conditioning, and water heating. The only exception is lighting. Savings from high-efficacy lighting requirements in the 2009 and 2012 IECC were included because they were an integral part of the building simulations conducted for this analysis. The following lighting efficiency requirements are present in all cases as follows:

1. 2006 IECC: Lighting per Building America benchmark.

2. 2009 IECC: 2006 IECC with 50\% high-efficacy lighting.

3. 2012 IECC: 2006 IECC with 75\% high-efficacy lighting.

It should be noted that the benchmark (2006 IECC) has a 34\% high-efficacy lighting provision. So, the only overlap is the increase from that benchmark level to meet $50 \%$ and $75 \%$ requirements for the 2009 and 2012 versions of the IECC.

Simulated energy performance estimates presented in Table 4.1 and Table 4.2 were used as a basis for calculating energy performance of the code versions before the 2006 IECC and after the 2012 IECC. For residential code versions predating the 2006 IECC, the energy performance was estimated based on the residential IECC improvement index developed by PNNL. The index is presented in Figure 4.1. 
Table 4.1. Residential Annual Energy Use for all IECC Regulated End-Uses, Electricity (site kWh/HH)

\begin{tabular}{|c|c|c|c|c|c|c|c|c|c|c|c|c|}
\hline \multirow[b]{2}{*}{ State } & \multicolumn{3}{|c|}{ Electr.Heating } & \multicolumn{3}{|c|}{ Electr.Cooling } & \multicolumn{3}{|c|}{ Electr.DomHotWater } & \multicolumn{3}{|c|}{ Electr.Other } \\
\hline & $\begin{array}{c}\text { IECC } \\
2006\end{array}$ & $\begin{array}{c}\text { IECC } \\
2009\end{array}$ & $\begin{array}{c}\text { IECC } \\
2012\end{array}$ & $\begin{array}{c}\text { IECC } \\
2006\end{array}$ & $\begin{array}{c}\text { IECC } \\
2009\end{array}$ & $\begin{array}{c}\text { IECC } \\
2012\end{array}$ & $\begin{array}{c}\text { IECC } \\
2006\end{array}$ & $\begin{array}{c}\text { IECC } \\
2009\end{array}$ & $\begin{array}{c}\text { IECC } \\
2012\end{array}$ & $\begin{array}{c}\text { IECC } \\
2006\end{array}$ & $\begin{array}{c}\text { IECC } \\
2009\end{array}$ & $\begin{array}{c}\text { IECC } \\
2012\end{array}$ \\
\hline Alabama & 3,041 & 2,655 & 1,454 & 4,391 & 3,664 & 3,148 & 2,140 & 2,140 & 1,925 & 1,812 & 1,516 & 1,296 \\
\hline Alaska & 10,416 & 9,232 & 5,807 & 317 & 319 & 388 & 1,874 & 1,874 & 1,686 & 1,948 & 1,629 & 1,393 \\
\hline Arizona & 902 & 798 & 518 & 8,856 & 7,410 & 6,425 & 532 & 532 & 478 & 1,922 & 1,608 & 1,375 \\
\hline Arkansas & 4,264 & 3,693 & 2,033 & 3,904 & 3,388 & 2,852 & 1,624 & 1,624 & 1,462 & 1,678 & 1,404 & 1,201 \\
\hline California & 909 & 775 & 338 & 1,655 & 1,281 & 1,344 & 1,131 & 1,131 & 1,017 & 1,653 & 1,383 & 1,182 \\
\hline Colorado & 2,806 & 2,478 & 1,567 & 1,673 & 1,607 & 1,609 & 900 & 900 & 809 & 1,826 & 1,527 & 1,306 \\
\hline Connecticut & 1,817 & 1,606 & 1,048 & 1,902 & 1,819 & 1,739 & 465 & 465 & 418 & 1,788 & 1,495 & 1,279 \\
\hline Delaware & 8,314 & 7,079 & 3,994 & 2,653 & 2,545 & 2,212 & 3,051 & 3,051 & 2,746 & 1,908 & 1,595 & 1,364 \\
\hline District of Columbia & 4,068 & 3,488 & 2,087 & 1,957 & 1,886 & 1,691 & 2,407 & 2,407 & 2,165 & 1,127 & 945 & 807 \\
\hline Florida & 803 & 719 & 477 & 6,927 & 5,787 & 5,084 & 1,930 & 1,930 & 1,737 & 1,815 & 1,518 & 1,298 \\
\hline Georgia & 3,959 & 3,428 & 1,857 & 4,367 & 3,659 & 3,128 & 2,525 & 2,525 & 2,271 & 1,895 & 1,584 & 1,355 \\
\hline Hawaii & 48 & 43 & 13 & 8,597 & 7,682 & 6,205 & 2,050 & 2,050 & 1,845 & 1,773 & 1,483 & 1,268 \\
\hline Idaho & 2,821 & 2,488 & 1,588 & 2,049 & 1,960 & 1,898 & 884 & 884 & 795 & 1,914 & 1,600 & 1,369 \\
\hline Illinois & 3,054 & 2,685 & 1,691 & 2,396 & 2,287 & 2,105 & 854 & 854 & 769 & 1,622 & 1,358 & 1,160 \\
\hline Indiana & 3,109 & 2,721 & 1,687 & 2,667 & 2,542 & 2,331 & 870 & 870 & 782 & 1,769 & 1,479 & 1,265 \\
\hline Iowa & 6,897 & 6,027 & 3,650 & 2,572 & 2,442 & 2,246 & 1,719 & 1,719 & 1,547 & 1,806 & 1,511 & 1,292 \\
\hline Kansas & 4,803 & 4,121 & 2,374 & 3,270 & 3,117 & 2,649 & 1,554 & 1,554 & 1,399 & 1,797 & 1,503 & 1,285 \\
\hline Kentucky & 6,771 & 5,775 & 3,304 & 2,598 & 2,500 & 2,199 & 2,572 & 2,572 & 2,314 & 1,788 & 1,495 & 1,279 \\
\hline Louisiana & 2,672 & 2,382 & 1,541 & 5,510 & 4,592 & 4,020 & 1,510 & 1,510 & 1,359 & 1,935 & 1,618 & 1,384 \\
\hline Maine & 2,706 & 2,384 & 1,465 & 1,214 & 1,169 & 1,184 & 535 & 535 & 482 & 1,978 & 1,654 & 1,415 \\
\hline Maryland & 6,427 & 5,473 & 3,101 & 2,689 & 2,576 & 2,241 & 2,844 & 2,844 & 2,560 & 1,748 & 1,462 & 1,250 \\
\hline Massachusetts & 1,902 & 1,670 & 1,060 & 1,730 & 1,656 & 1,615 & 459 & 459 & 412 & 1,765 & 1,476 & 1,262 \\
\hline Michigan & 4,509 & 3,949 & 2,420 & 1,691 & 1,615 & 1,559 & 993 & 993 & 894 & 1,882 & 1,574 & 1,346 \\
\hline Minnesota & 8,359 & 7,349 & 4,431 & 1,656 & 1,576 & 1,497 & 1,841 & 1,841 & 1,657 & 1,734 & 1,451 & 1,241 \\
\hline Mississippi & 3,291 & 2,872 & 1,671 & 4,824 & 4,024 & 3,482 & 2,145 & 2,145 & 1,930 & 1,881 & 1,573 & 1,345 \\
\hline Missouri & 4,556 & 3,925 & 2,299 & 3,214 & 3,068 & 2,647 & 1,501 & 1,501 & 1,350 & 1,729 & 1,447 & 1,237 \\
\hline Montana & 3,337 & 2,948 & 1,858 & 1,250 & 1,200 & 1,207 & 933 & 933 & 840 & 1,724 & 1,442 & 1,233 \\
\hline Nebraska & 5,396 & 4,727 & 2,937 & 2,784 & 2,637 & 2,386 & 1,613 & 1,613 & 1,451 & 1,716 & 1,435 & 1,227 \\
\hline Nevada & 1,616 & 1,399 & 760 & 5,847 & 4,955 & 3,991 & 647 & 648 & 582 & 1,891 & 1,582 & 1,352 \\
\hline New Hampshire & 2,156 & 1,914 & 1,240 & 1,622 & 1,552 & 1,503 & 489 & 489 & 440 & 1,821 & 1,523 & 1,303 \\
\hline New Jersey & 2,949 & 2,549 & 1,522 & 2,269 & 2,175 & 1,966 & 941 & 941 & 847 & 1,667 & 1,395 & 1,193 \\
\hline New Mexico & 2,086 & 1,812 & 1,052 & 3,280 & 2,992 & 2,638 & 778 & 778 & 700 & 1,913 & 1,600 & 1,368 \\
\hline New York & 3,546 & 3,086 & 1,847 & 1,637 & 1,575 & 1,515 & 999 & 999 & 898 & 1,629 & 1,363 & 1,165 \\
\hline North Carolina & 4,203 & 3,618 & 2,014 & 3,533 & 3,163 & 2,725 & 2,622 & 2,622 & 2,359 & 1,808 & 1,512 & 1,293 \\
\hline North Dakota & 8,769 & 7,746 & 4,739 & 1,366 & 1,311 & 1,270 & 1,811 & 1,811 & 1,629 & 1,530 & 1,281 & 1,094 \\
\hline Ohio & 2,839 & 2,496 & 1,579 & 2,050 & 1,959 & 1,868 & 888 & 888 & 799 & 1,798 & 1,504 & 1,286 \\
\hline Oklahoma & 5,697 & 4,908 & 2,560 & 4,496 & 3,796 & 3,116 & 1,712 & 1,712 & 1,540 & 1,882 & 1,574 & 1,346 \\
\hline Oregon & 2,800 & 2,482 & 1,621 & 1,353 & 1,303 & 1,327 & 1,389 & 1,389 & 1,250 & 1,830 & 1,530 & 1,309 \\
\hline Pennsylvania & 3,875 & 3,402 & 2,119 & 2,516 & 2,394 & 2,177 & 1,035 & 1,035 & 931 & 1,933 & 1,616 & 1,383 \\
\hline Rhode Island & 1,957 & 1,725 & 1,112 & 1,862 & 1,783 & 1,726 & 473 & 473 & 426 & 1,877 & 1,570 & 1,342 \\
\hline South Carolina & 3,566 & 3,082 & 1,607 & 4,743 & 4,008 & 3,346 & 2,495 & 2,496 & 2,245 & 1,941 & 1,623 & 1,388 \\
\hline South Dakota & 7,635 & 6,663 & 3,942 & 2,148 & 2,044 & 1,898 & 1,758 & 1,758 & 1,582 & 1,764 & 1,476 & 1,262 \\
\hline Tennessee & 4,339 & 3,713 & 2,114 & 3,704 & 3,477 & 2,991 & 2,281 & 2,280 & 2,053 & 1,742 & 1,458 & 1,246 \\
\hline Texas & 2,400 & 2,125 & 1,306 & 5,537 & 4,644 & 4,019 & 1,437 & 1,437 & 1,293 & 1,796 & 1,502 & 1,284 \\
\hline Utah & 2,351 & 2,081 & 1,347 & 2,815 & 2,584 & 2,382 & 815 & 815 & 733 & 1,818 & 1,521 & 1,300 \\
\hline Vermont & 2,611 & 2,286 & 1,410 & 1,416 & 1,354 & 1,346 & 510 & 510 & 459 & 1,850 & 1,547 & 1,323 \\
\hline Virginia & 5,401 & 4,621 & 2,632 & 3,328 & 3,182 & 2,731 & 2,768 & 2,768 & 2,491 & 1,860 & 1,555 & 1,330 \\
\hline Washington & 3,318 & 2,916 & 1,863 & 1,009 & 980 & 1,040 & 1,432 & 1,432 & 1,288 & 1,780 & 1,489 & 1,273 \\
\hline West Virginia & 7,683 & 6,690 & 4,036 & 2,177 & 2,095 & 1,896 & 3,045 & 3,045 & 2,740 & 1,788 & 1,496 & 1,280 \\
\hline Wisconsin & 4,669 & 4,120 & 2,545 & 1,755 & 1,667 & 1,571 & 980 & 980 & 882 & 1,724 & 1,442 & 1,233 \\
\hline Wyoming & 3,620 & 3,167 & 1,891 & 1,136 & 1,094 & 1,114 & 937 & 937 & 843 & 1,742 & 1,457 & 1,247 \\
\hline
\end{tabular}


Table 4.2. Residential Annual Energy Use for all IECC Regulated End-Uses, Natural Gas, and Heating Oil (therm/HH)

\begin{tabular}{|c|c|c|c|c|c|c|c|c|c|c|c|c|}
\hline \multirow[b]{2}{*}{ State } & \multicolumn{3}{|c|}{ Gas Heating } & \multicolumn{3}{|c|}{ Gas DomHotWater } & \multicolumn{3}{|c|}{ Oil Heating } & \multicolumn{3}{|c|}{ Oil DomHotWater } \\
\hline & $\begin{array}{c}\text { IECC } \\
2006\end{array}$ & $\begin{array}{c}\text { IECC } \\
2009\end{array}$ & $\begin{array}{c}\text { IECC } \\
2012\end{array}$ & $\begin{array}{c}\text { IECC } \\
2006\end{array}$ & $\begin{array}{c}\text { IECC } \\
2009\end{array}$ & $\begin{array}{c}\text { IECC } \\
2012\end{array}$ & $\begin{array}{c}\text { IECC } \\
2006\end{array}$ & $\begin{array}{c}\text { IECC } \\
2009\end{array}$ & $\begin{array}{c}\text { IECC } \\
2012\end{array}$ & $\begin{array}{c}\text { IECC } \\
2006\end{array}$ & $\begin{array}{c}\text { IECC } \\
2009\end{array}$ & $\begin{array}{r}\text { IECC } \\
2012\end{array}$ \\
\hline Alabama & 100 & 89 & 46 & 49 & 49 & 44 & - & - & - & - & - & - \\
\hline Alaska & 949 & 841 & 519 & 162 & 162 & 145 & 3 & 3 & 2 & 1 & 1 & - \\
\hline Arizona & 136 & 123 & 73 & 112 & 112 & 101 & - & - & - & - & - & - \\
\hline Arkansas & 232 & 202 & 107 & 84 & 84 & 75 & - & - & - & - & - & - \\
\hline California & 107 & 92 & 34 & 108 & 108 & 96 & - & - & - & - & - & - \\
\hline Colorado & 518 & 456 & 270 & 168 & 168 & 150 & 1 & 1 & 1 & - & - & - \\
\hline Connecticut & 422 & 372 & 223 & 118 & 118 & 107 & 230 & 202 & 122 & 64 & 64 & 58 \\
\hline Delaware & 148 & 128 & 71 & 38 & 38 & 34 & 1 & 1 & - & - & - & - \\
\hline District of Columbia & 73 & 63 & 36 & 31 & 31 & 29 & - & - & - & - & - & - \\
\hline Florida & 17 & 16 & 10 & 27 & 27 & 24 & - & - & - & - & - & - \\
\hline Georgia & 78 & 69 & 36 & 33 & 33 & 29 & - & - & - & - & - & - \\
\hline Hawaii & - & - & - & - & - & - & - & - & - & - & - & - \\
\hline Idaho & 538 & 472 & 279 & 166 & 166 & 149 & 1 & 1 & 1 & - & - & - \\
\hline Illinois & 561 & 494 & 296 & 151 & 151 & 136 & 4 & 3 & 2 & 1 & 1 & 1 \\
\hline Indiana & 573 & 505 & 300 & 153 & 153 & 137 & 4 & 3 & 2 & 1 & 1 & 1 \\
\hline Iowa & 538 & 474 & 281 & 120 & 120 & 108 & 2 & 2 & 1 & - & - & - \\
\hline Kansas & 405 & 350 & 195 & 110 & 110 & 99 & 2 & 1 & 1 & - & - & - \\
\hline Kentucky & 195 & 170 & 95 & 56 & 56 & 51 & - & - & - & - & - & - \\
\hline Louisiana & 149 & 134 & 83 & 79 & 79 & 71 & - & - & - & - & - & - \\
\hline Maine & 607 & 534 & 308 & 133 & 133 & 119 & 331 & 291 & 168 & 72 & 72 & 65 \\
\hline Maryland & 119 & 102 & 56 & 36 & 36 & 32 & 1 & 1 & - & - & - & - \\
\hline Massachusetts & 452 & 395 & 227 & 117 & 117 & 105 & 246 & 215 & 124 & 64 & 64 & 57 \\
\hline Michigan & 807 & 712 & 426 & 171 & 170 & 154 & 6 & 5 & 3 & 1 & 1 & 1 \\
\hline Minnesota & 627 & 552 & 327 & 126 & 126 & 114 & 2 & 2 & 1 & - & - & - \\
\hline Mississippi & 109 & 96 & 54 & 49 & 49 & 43 & - & - & - & - & - & - \\
\hline Missouri & 386 & 335 & 189 & 108 & 108 & 96 & 2 & 1 & 1 & - & - & - \\
\hline Montana & 632 & 557 & 333 & 173 & 173 & 155 & 2 & 2 & 1 & - & - & - \\
\hline Nebraska & 435 & 383 & 232 & 114 & 114 & 103 & 2 & 2 & 1 & - & - & - \\
\hline Nevada & 269 & 234 & 113 & 129 & 129 & 116 & 1 & 1 & - & - & - & - \\
\hline New Hampshire & 480 & 424 & 255 & 123 & 123 & 110 & 262 & 231 & 139 & 67 & 67 & 61 \\
\hline New Jersey & 472 & 410 & 233 & 134 & 134 & 121 & 32 & 27 & 16 & 8 & 8 & 8 \\
\hline New Mexico & 388 & 335 & 174 & 149 & 149 & 133 & 1 & 1 & - & - & - & - \\
\hline New York & 544 & 476 & 278 & 141 & 141 & 126 & 36 & 32 & 19 & 10 & 10 & 9 \\
\hline North Carolina & 81 & 71 & 36 & 34 & 34 & 30 & - & - & - & - & - & - \\
\hline North Dakota & 605 & 534 & 320 & 125 & 125 & 112 & 2 & 2 & 2 & - & - & - \\
\hline Ohio & 537 & 473 & 286 & 156 & 156 & 140 & 3 & 3 & 2 & 1 & 1 & 1 \\
\hline Oklahoma & 308 & 267 & 135 & 87 & 87 & 78 & - & - & - & - & - & - \\
\hline Oregon & 322 & 282 & 164 & 127 & 127 & 114 & 1 & 1 & 1 & - & - & - \\
\hline Pennsylvania & 587 & 518 & 309 & 145 & 145 & 130 & 39 & 34 & 21 & 10 & 10 & 9 \\
\hline Rhode Island & 456 & 400 & 234 & 120 & 120 & 108 & 249 & 219 & 128 & 65 & 65 & 59 \\
\hline South Carolina & 69 & 62 & 29 & 33 & 33 & 30 & - & - & - & - & - & - \\
\hline South Dakota & 565 & 497 & 288 & 122 & 122 & 110 & 2 & 2 & 1 & - & - & - \\
\hline Tennessee & 133 & 115 & 63 & 51 & 51 & 47 & - & - & - & - & - & - \\
\hline Texas & 133 & 119 & 70 & 76 & 76 & 68 & - & - & - & - & - & - \\
\hline Utah & 424 & 373 & 218 & 155 & 155 & 139 & 1 & 1 & 1 & - & - & - \\
\hline Vermont & 585 & 515 & 301 & 127 & 127 & 115 & 319 & 281 & 164 & 70 & 70 & 63 \\
\hline Virginia & 99 & 86 & 46 & 36 & 36 & 32 & 1 & - & - & - & - & - \\
\hline Washington & 376 & 329 & 193 & 130 & 130 & 116 & 1 & 1 & 1 & - & - & - \\
\hline West Virginia & 122 & 108 & 64 & 38 & 38 & 34 & 1 & 1 & - & - & - & - \\
\hline Wisconsin & 798 & 706 & 419 & 169 & 169 & 151 & 5 & 4 & 3 & 1 & 1 & 1 \\
\hline Wyoming & 673 & 589 & 333 & 173 & 173 & 155 & 2 & 2 & 1 & - & - & - \\
\hline
\end{tabular}




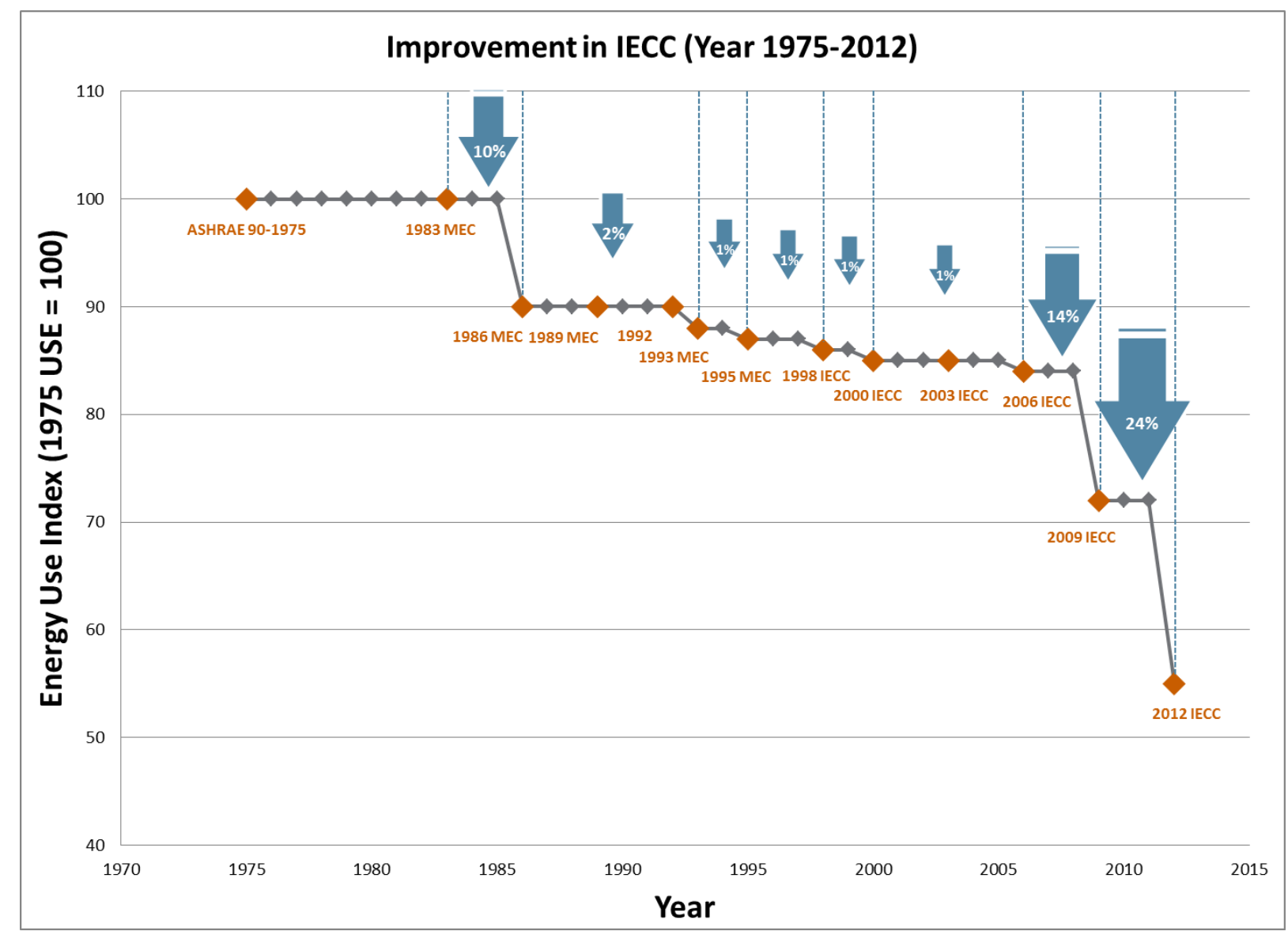

Figure 4.1. IECC Residential Energy Improvement Index

The retroactive code performance scalars for versions between the 1989 MEC and the 2003 IECC were developed from this index using 2006 IECC simulated EUIs as the base. For the code versions prior to the 2006 IECC, BECP is not credited with the energy improvements related to code development. For the 2006, 2009 and 2012 IECC, BECP is credited with 75\%, 30\%, and 30\% of the code-to-code energy efficiency improvement, respectively. These internal estimates are based on the professional judgment of staff involved in code support. This means that if there were a $24 \%$ reduction in the EUI between the 2009 IECC and the 2006 IECC in the "with BECP" scenario, we assumed that without the DOE assistance in place the code would have advanced by about $16 \%$ instead.

Consistent with BECP shifting from a focus on code development in the past to more support for improvement in code implementation in the future, only $0.5 \%$ of the code-to-code energy efficiency improvement was attributed to BECP for the code versions after the 2012 IECC. It was assumed that in the "with BECP" scenario there would be a 5\% improvement in the energy use per code cycle, while a $4.5 \%$ improvement is expected without the DOE program in place.

Nominal code-to-code energy savings were derived from the code energy performance estimates by comparing the code version that is adopted in the state to the previously active code version. Nominal energy savings were then adjusted by the compliance rates. Residential adoption and compliance assumptions are described in Sections 4.3 and 4.4 . 


\subsection{Residential Floor Space Forecast}

Calculating new floor space is integral to the analysis of building energy codes because the potential energy savings are estimated by square foot. However, there are no publicly available data sources that show annual new floor space of residential buildings constructed by state. A further complication is that building codes apply not only to new square footage, but also to additions and major alterations.

The estimates for household stock additions via new construction of single-family and low-rise multifamily buildings, and floor space additions (in terms of household equivalents) to existing singlefamily homes were combined into one time-series of code-relevant housing additions. Only newly-added space was included; no impacts associated with alterations to existing floor space were incorporated in the estimate. ${ }^{13}$ The code-to-code savings were then applied to this housing projection for calculating the national energy benefits of the BECP residential activities. The estimation of the code-applicable floor space is discussed in detail below.

\subsubsection{Historical Data for New Residential Construction}

Census residential building permit data, for the years 1992 through 2012, were used to develop a time-series of estimated historical completions. Permit data were used, rather than actual census completion data, because permits are available at the state level, whereas completion data are only available at the census region level. The census provides the permit data categorized into the following living unit-based categories:

- 1 unit

- 2 units

- 3 and 4 units

- 5 units or more.

State-level estimates of single-family and low-rise multifamily units are required. For multifamily units, residential building codes only apply to low-rise buildings, i.e., buildings having three or fewer stories above grade, so it is necessary to estimate the fraction of units in the " 5 units or more" category that are in low-rise buildings. To accomplish this, several steps were taken:

- Utilized the data from the 2009 Residential Energy Consumption Survey (RECS Table HC2.1). This table categorizes multifamily units, in buildings with five or more units, into various "number of floor" categories.

- Assumed that $60 \%{ }^{14}$ of the units in the "3-4 Floors" category were in three-floored buildings.

- Added the resulting number of units in three-floored buildings to those in the "1-2 Floors" category, and then divided by the total number of units, which yielded a fraction of units in five-plus unit buildings that are classified as low-rise.

- Applied this fraction to the annual census permit data in order to derive state-level estimates of single-family and low-rise multifamily units.

\footnotetext{
${ }^{13}$ Based on analysis of the American Housing Survey, alterations accounted for about $0.1 \%$ of the existing floor space, with energy-significant alterations comprising only a fraction of that.

${ }^{14}$ Based on the analysis of RECS and CBECS.
} 
Additionally, the fraction of multifamily units classified as low-rise was also estimated by applying the fraction discussed in the previous paragraph to 10 years (2003-2012) of the census permit data. This result was later applied to the AEO-derived multifamily household data to extract an estimate of low-rise multifamily households.

To account for the lag between the permitting and completion of a building, census permit data were converted to estimated completions by introducing a lag of 6 months. ${ }^{15}$

\subsubsection{Projected Data for New Construction and Additions to Existing Residential Buildings}

The AEO 2012 Reference Case forecasts residential stock (in terms of households) by housing type (single-family, multifamily, and manufactured home) and the nine census divisions. Annual residential stock survival factors from EIA's National Energy Modeling System (NEMS) residential documentation (EIA 2013) were applied to the stock to derive a forecast of additions to residential stock. The survival factors are:

$$
\begin{array}{ll}
\text { Single-family stock survival factor: } & 0.996 \\
\text { Multifamily stock survival factor: } & 0.999 \\
\text { Manufactured home stock survival factor: } & 0.976
\end{array}
$$

Given that the AEO multifamily data include both low-rise and high-rise multifamily households, it was necessary to apply the fraction of multifamily units classified as low-rise discussed in Section 4.2.1. Adding the resulting low-rise multifamily data to the single-family data provided a forecast of household additions to stock potentially impacted by the residential energy codes.

New construction is not the only means by which building energy codes may provide energy savings. Additions to existing homes are also subject to the energy codes. Estimates of floor space additions due to expansions of existing single-family homes are necessary to capture such impacts. Key steps, assumptions, and details included in this estimation were as follows:

- It was assumed that expansion of existing homes only occurs in the case of single-family, rather than multifamily, homes.

- The single-family stock survival factor was used to calculate surviving stock.

- Based on information included in the NEMS residential documentation, it was assumed that $1 \%$ of the surviving, existing single-family stock receives a $600-\mathrm{ft}^{2}$ addition in a given year.

- The results were converted to household equivalents, obtained by dividing the added floor space by the size of a prototype single-family home. This prototype, single-family home was assumed to contain 2,400 $\mathrm{ft}^{2}$ (Taylor et al. 2012, Table 2.1).

- Year-specific ratios of added floor space (in terms of household equivalents) to households added via new construction were calculated. The national-level ratios were later used as scalars to convert state-level new construction numbers to values that include additions to existing single-family homes.

\footnotetext{
${ }^{15}$ For more detailed data on the typical lag between starts and completions, see census statistics available at http://www.census.gov/construction/nrc/lengthoftime.html.
} 


\subsubsection{Integration of Historical and Projected Residential Data}

Census-based historical data and the AEO-derived forecast combined into a single time-series served as an estimate of the housing stock impacted by the residential energy codes. The census data are at the state level, and provide data for the years 1992 through 2012. The AEO data are at the census division level, and include data for the years 2005 through 2040. To generate consistent, state-level time-series data through 2040, the following steps were taken:

- Census division-level growth rates embedded in the AEO data were applied to the state-level census data, with the 2012 census data used as the base. This step relied on the implicit assumption that states' shares within each census division remain constant at 2012 levels.

- Expansions of surviving, single-family homes, in terms of household equivalents, were then added to the forecast.

- Previously mentioned national, year-specific scalars were applied to the state-level additions to stock data to integrate additions of space to existing homes.

The resulting estimates represent additions to household stock via new construction of single-family and low-rise multifamily buildings, and additions of floor space (in terms of household equivalents) to existing single-family homes. Only newly added space was included; no impacts associated with alterations to existing floor space were incorporated in the estimate. The code-to-code savings were applied to this housing projection for calculating national energy benefits of the residential BECP activities.

\subsection{Adoption of Residential Energy Codes}

The same methodology developed for the commercial analysis was used for residential (see Section 3.3). However, the historical explicit, implicit, future adoptions, and counterfactual scenario assumptions for residential energy codes differ from the commercial analysis. Some states adopt residential codes on a different code cycle than commercial or have no code cycle in place for residential but might for commercial. Currently, 43 states have adopted a residential building energy code. The following tables present the residential energy code adoption assumptions and categorizations.

Table 4.4 shows the start of the residential savings stream for both explicit and implicit adoption years. Implicit adoption years are highlighted in orange.

Although the same approach for categorization is used in both the residential and commercial analyses, BECP tracks adoption for commercial and residential energy codes separately. Therefore, the state allocation across the adoption groups is different as presented in Table 4.5. There are six states whose classification varies between residential and commercial: Kentucky, Louisiana, Utah, Vermont, Virginia, and Wisconsin. 
Table 4.3. Start Year for Crediting States with Residential Energy Code Savings Based on the Newly Adopted Code

\begin{tabular}{|c|c|c|c|c|c|c|}
\hline State & MEC 92-95 & IECC 1998/2000 & IECC 2003 & IECC 2006 & IECC 2009 & IECC 2012 \\
\hline Alabama & & & & & 2013 & \\
\hline \multicolumn{7}{|l|}{ Alaska } \\
\hline \multicolumn{7}{|l|}{ Arizona } \\
\hline Arkansas & 1995 & & 2005 & & & \\
\hline California & 1994 & 2003 & & 2006 & 2010 & \\
\hline Colorado & 1996 & & 2005 & 2008 & & \\
\hline Connecticut & 1999 & & 2005 & 2009 & 2012 & \\
\hline Delaware & 1996 & 2004 & & & 2010 & \\
\hline District of Columbia & 2000 & 2004 & & & 2010 & \\
\hline Florida & 1993 & 2002 & 2005 & & 2012 & \\
\hline Georgia & 1996 & 2004 & & 2008 & 2011 & \\
\hline Hawaii & 1997 & & & 2010 & & \\
\hline Idaho & & 2003 & 2005 & 2008 & 2011 & \\
\hline Illinois & & & & & 2010 & 2013 \\
\hline Indiana & 1993 & & & & 2012 & \\
\hline Iowa & 1993 & & 2004 & 2007 & 2010 & \\
\hline \multicolumn{7}{|l|}{ Kansas } \\
\hline Kentucky & 1997 & 2005 & & 2007 & 2012 & \\
\hline Louisiana & & & & 2011 & & \\
\hline Maine & & & 2005 & & 2011 & \\
\hline Maryland & 1997 & 2001 & 2005 & 2007 & 2010 & 2012 \\
\hline Massachusetts & 1998 & 2001 & & 2008 & 2010 & \\
\hline Michigan & & & 2009 & & 2011 & \\
\hline Minnesota & 2000 & & & 2009 & & \\
\hline \multicolumn{7}{|l|}{ Mississippi } \\
\hline \multicolumn{7}{|l|}{ Missouri } \\
\hline Montana & 1993 & & 2005 & & 2010 & \\
\hline Nebraska & & & 2005 & & 2012 & \\
\hline Nevada & & & 2005 & 2010 & 2012 & \\
\hline New Hampshire & 1999 & 2002 & & 2007 & 2010 & \\
\hline New Jersey & 1997 & & 2002 & 2007 & 2011 & \\
\hline New Mexico & 1994 & & 2004 & 2008 & 2012 & \\
\hline New York & 1992 & 2002 & 2008 & & 2011 & \\
\hline North Carolina & 1993 & 2002 & 2006 & 2009 & 2012 & \\
\hline North Dakota & & & & & 2011 & \\
\hline Ohio & 1995 & 2002 & 2005 & 2009 & 2013 & \\
\hline Oklahoma & & & & & 2011 & \\
\hline Oregon & 1992 & 2003 & 2005 & 2008 & 2011 & \\
\hline Pennsylvania & & & 2004 & 2007 & 2010 & \\
\hline Rhode Island & 1997 & 2002 & 2004 & 2007 & 2010 & \\
\hline South Carolina & 1998 & 2001 & 2005 & 2009 & 2013 & \\
\hline \multicolumn{7}{|l|}{ South Dakota } \\
\hline Tennessee & & & 2009 & 2011 & & \\
\hline Texas & & 2001 & & & 2012 & \\
\hline Utah & 1995 & 2002 & 2004 & 2007 & & \\
\hline Vermont & 1998 & 2005 & & & 2012 & \\
\hline Virginia & 1993 & 2004 & 2006 & 2008 & 2011 & \\
\hline Washington & 1994 & 2002 & 2005 & 2007 & 2011 & 2013 \\
\hline West Virginia & & 2003 & 2006 & & 2012 & \\
\hline Wisconsin & 1999 & & & 2009 & & \\
\hline Wyoming & & & & & & \\
\hline
\end{tabular}


Table 4.4. Start of the Residential Savings Stream Based on Explicit and Implicit Adoption

\begin{tabular}{|c|c|c|c|c|c|c|}
\hline State & MEC 92-95 & IECC 1998/2000 & IECC 2003 & IECC 2006 & IECC 2009 & IECC 2012 \\
\hline Alabama & 2002 & 2008 & 2013 & 2013 & 2013 & \\
\hline Alaska & 2002 & 2008 & 2013 & 2016 & & \\
\hline Arizona & 2002 & 2008 & 2013 & 2016 & & \\
\hline Arkansas & 1995 & 2005 & 2005 & 2016 & & \\
\hline California & 1994 & 2003 & 2006 & 2006 & 2010 & \\
\hline Colorado & 1996 & 2005 & 2005 & 2008 & & \\
\hline Connecticut & 1999 & 2005 & 2005 & 2009 & 2012 & \\
\hline Delaware & 1996 & 2004 & 2010 & 2010 & 2010 & \\
\hline District of Columbia & 2000 & 2004 & 2010 & 2010 & 2010 & \\
\hline Florida & 1993 & 2002 & 2005 & 2012 & 2012 & \\
\hline Georgia & 1996 & 2004 & 2008 & 2008 & 2011 & \\
\hline Hawaii & 1997 & 2008 & 2010 & 2010 & & \\
\hline Idaho & 2002 & 2003 & 2005 & 2008 & 2011 & \\
\hline Illinois & 2002 & 2008 & 2010 & 2010 & 2010 & 2013 \\
\hline Indiana & 1993 & 2008 & 2012 & 2012 & 2012 & \\
\hline Iowa & 1993 & 2004 & 2004 & 2007 & 2010 & \\
\hline Kansas & 2002 & 2008 & 2013 & 2016 & & \\
\hline Kentucky & 1997 & 2005 & 2007 & 2007 & 2012 & \\
\hline Louisiana & 2002 & 2008 & 2011 & 2011 & & \\
\hline Maine & 2002 & 2005 & 2005 & 2011 & 2011 & \\
\hline Maryland & 1997 & 2001 & 2005 & 2007 & 2010 & 2012 \\
\hline Massachusetts & 1998 & 2001 & 2008 & 2008 & 2010 & \\
\hline Michigan & 2002 & 2008 & 2009 & 2011 & 2011 & \\
\hline Minnesota & 2000 & 2008 & 2009 & 2009 & & \\
\hline Mississippi & 2002 & 2008 & 2013 & 2016 & & \\
\hline Missouri & 2002 & 2008 & 2013 & 2016 & & \\
\hline Montana & 1993 & 2005 & 2005 & 2010 & 2010 & \\
\hline Nebraska & 2002 & 2005 & 2005 & 2012 & 2012 & \\
\hline Nevada & 2002 & 2005 & 2005 & 2010 & 2012 & \\
\hline New Hampshire & 1999 & 2002 & 2007 & 2007 & 2010 & \\
\hline New Jersey & 1997 & 2002 & 2002 & 2007 & 2011 & \\
\hline New Mexico & 1994 & 2004 & 2004 & 2008 & 2012 & \\
\hline New York & 1992 & 2002 & 2008 & 2011 & 2011 & \\
\hline North Carolina & 1993 & 2002 & 2006 & 2009 & 2012 & \\
\hline North Dakota & 2002 & 2008 & 2011 & 2011 & 2011 & \\
\hline Ohio & 1995 & 2002 & 2005 & 2009 & 2013 & \\
\hline Oklahoma & 2002 & 2008 & 2011 & 2011 & 2011 & \\
\hline Oregon & 1992 & 2003 & 2005 & 2008 & 2011 & \\
\hline Pennsylvania & 2002 & 2004 & 2004 & 2007 & 2010 & \\
\hline Rhode Island & 1997 & 2002 & 2004 & 2007 & 2010 & \\
\hline South Carolina & 1998 & 2001 & 2005 & 2009 & 2013 & \\
\hline South Dakota & 2002 & 2008 & 2013 & 2016 & & \\
\hline Tennessee & 2002 & 2008 & 2009 & 2011 & & \\
\hline Texas & 2001 & 2001 & 2012 & 2012 & 2012 & \\
\hline Utah & 1995 & 2002 & 2004 & 2007 & & \\
\hline Vermont & 1998 & 2005 & 2012 & 2012 & 2012 & \\
\hline Virginia & 1993 & 2004 & 2006 & 2008 & 2011 & \\
\hline Washington & 1994 & 2002 & 2005 & 2007 & 2011 & 2013 \\
\hline West Virginia & 2002 & 2003 & 2006 & 2012 & 2012 & \\
\hline Wisconsin & 1999 & 2008 & 2009 & 2009 & & \\
\hline Wyoming & 2002 & 2008 & 2013 & 2016 & & \\
\hline
\end{tabular}


Table 4.5. State Classifications for Future Residential Energy Code Adoption

\begin{tabular}{lll}
\hline $\begin{array}{c}\text { Aggressive } \\
\text { (code version year }+1 \text { year) }\end{array}$ & $\begin{array}{c}\text { Moderate } \\
\text { (code version year }+4 \text { years) }\end{array}$ & $\begin{array}{c}\text { Slow } \\
\text { (code version year }+7 \text { years) }\end{array}$ \\
\hline California & Connecticut & Alabama \\
Florida & Delaware & Alaska \\
Georgia & District of Columbia & Arizona \\
Illinois & Idaho & Arkansas \\
Iowa & Kentucky & Colorado \\
Maryland & Maine & Hawaii \\
Massachusetts & Michigan & Indiana \\
New Hampshire & Montana & Kansas \\
New York & Nebraska & Louisiana \\
North Carolina & Nevada & Minnesota \\
Oregon & New Jersey & Mississippi \\
Rhode Island & New Mexico & Missouri \\
Virginia & Ohio & North Dakota \\
Washington & Pennsylvania & Oklahoma \\
& South Carolina & South Dakota \\
& Texas & Tennessee \\
& & Utah \\
& & Vermont \\
& & West Virginia \\
& & Wisconsin \\
& & Wyoming \\
\hline
\end{tabular}

The full set of residential code adoption assumptions for both scenarios ("with BECP" and "without BECP") is included in Table 4.6 and Table 4.7. Projected adoption years are highlighted in grey. 
Table 4.6. Residential Energy Code Adoption Assumptions for the Scenario "with BECP"

\begin{tabular}{|c|c|c|c|c|c|c|c|c|c|c|c|}
\hline & & $\begin{array}{l}\text { MEC } \\
92-95\end{array}$ & $\begin{array}{c}\text { IECC } \\
1998 / 2000\end{array}$ & $\begin{array}{c}\text { IECC } \\
2003\end{array}$ & $\begin{array}{c}\text { IECC } \\
2006\end{array}$ & $\begin{array}{c}\text { IECC } \\
2009\end{array}$ & $\begin{array}{c}\text { IECC } \\
2012\end{array}$ & $\begin{array}{c}\text { IECC } \\
2015\end{array}$ & $\begin{array}{c}\text { IECC } \\
2018\end{array}$ & $\begin{array}{c}\text { IECC } \\
2021\end{array}$ & $\begin{array}{c}\text { IECC } \\
2024\end{array}$ \\
\hline $\mathrm{S}$ & Alabama & 2002 & 2008 & 2013 & 2013 & 2013 & 2019 & 2022 & 2025 & 2028 & 2031 \\
\hline $\mathrm{S}$ & Alaska & 2002 & 2008 & 2013 & 2016 & 2016 & 2019 & 2022 & 2025 & 2028 & 2031 \\
\hline $\mathrm{S}$ & Arizona & 2002 & 2008 & 2013 & 2016 & 2016 & 2019 & 2022 & 2025 & 2028 & 2031 \\
\hline $\mathrm{S}$ & Arkansas & 1995 & 2005 & 2005 & 2016 & 2016 & 2019 & 2022 & 2025 & 2028 & 2031 \\
\hline A & California & 1994 & 2003 & 2006 & 2006 & 2010 & 2013 & 2016 & 2019 & 2022 & 2025 \\
\hline $\mathrm{S}$ & Colorado & 1996 & 2005 & 2005 & 2008 & 2016 & 2019 & 2022 & 2025 & 2028 & 2031 \\
\hline M & Connecticut & 1999 & 2005 & 2005 & 2009 & 2012 & 2016 & 2019 & 2022 & 2025 & 2028 \\
\hline $\mathrm{M}$ & $\begin{array}{l}\text { Delaware } \\
\text { District of }\end{array}$ & 1996 & 2004 & 2010 & 2010 & 2010 & 2016 & 2019 & 2022 & 2025 & 2028 \\
\hline M & Columbia & 2000 & 2004 & 2010 & 2010 & 2010 & 2016 & 2019 & 2022 & 2025 & 2028 \\
\hline A & Florida & 1993 & 2002 & 2005 & 2012 & 2012 & 2013 & 2016 & 2019 & 2022 & 2025 \\
\hline A & Georgia & 1996 & 2004 & 2008 & 2008 & 2011 & 2013 & 2016 & 2019 & 2022 & 2025 \\
\hline $\mathrm{S}$ & Hawaii & 1997 & 2008 & 2010 & 2010 & 2016 & 2019 & 2022 & 2025 & 2028 & 2031 \\
\hline $\mathrm{M}$ & Idaho & 2002 & 2003 & 2005 & 2008 & 2011 & 2016 & 2019 & 2022 & 2025 & 2028 \\
\hline A & Illinois & 2002 & 2008 & 2010 & 2010 & 2010 & 2013 & 2016 & 2019 & 2022 & 2025 \\
\hline $\mathrm{S}$ & Indiana & 1993 & 2008 & 2012 & 2012 & 2012 & 2019 & 2022 & 2025 & 2028 & 2031 \\
\hline A & Iowa & 1993 & 2004 & 2004 & 2007 & 2010 & 2013 & 2016 & 2019 & 2022 & 2025 \\
\hline $\mathrm{S}$ & Kansas & 2002 & 2008 & 2013 & 2016 & 2016 & 2019 & 2022 & 2025 & 2028 & 2031 \\
\hline $\mathrm{M}$ & Kentucky & 1997 & 2005 & 2007 & 2007 & 2012 & 2016 & 2019 & 2022 & 2025 & 2028 \\
\hline $\mathrm{S}$ & Louisiana & 2002 & 2008 & 2011 & 2011 & 2016 & 2019 & 2022 & 2025 & 2028 & 2031 \\
\hline M & Maine & 2002 & 2005 & 2005 & 2011 & 2011 & 2016 & 2019 & 2022 & 2025 & 2028 \\
\hline A & Maryland & 1997 & 2001 & 2005 & 2007 & 2010 & 2012 & 2016 & 2019 & 2022 & 2025 \\
\hline A & Massachusetts & 1998 & 2001 & 2008 & 2008 & 2010 & 2013 & 2016 & 2019 & 2022 & 2025 \\
\hline M & Michigan & 2002 & 2008 & 2009 & 2011 & 2011 & 2016 & 2019 & 2022 & 2025 & 2028 \\
\hline $\mathrm{S}$ & Minnesota & 2000 & 2008 & 2009 & 2009 & 2016 & 2019 & 2022 & 2025 & 2028 & 2031 \\
\hline $\mathrm{S}$ & Mississippi & 2002 & 2008 & 2013 & 2016 & 2016 & 2019 & 2022 & 2025 & 2028 & 2031 \\
\hline $\mathrm{S}$ & Missouri & 2002 & 2008 & 2013 & 2016 & 2016 & 2019 & 2022 & 2025 & 2028 & 2031 \\
\hline $\mathrm{M}$ & Montana & 1993 & 2005 & 2005 & 2010 & 2010 & 2016 & 2019 & 2022 & 2025 & 2028 \\
\hline M & Nebraska & 2002 & 2005 & 2005 & 2012 & 2012 & 2016 & 2019 & 2022 & 2025 & 2028 \\
\hline M & Nevada & 2002 & 2005 & 2005 & 2010 & 2012 & 2016 & 2019 & 2022 & 2025 & 2028 \\
\hline $\mathrm{A}$ & New Hampshire & 1999 & 2002 & 2007 & 2007 & 2010 & 2013 & 2016 & 2019 & 2022 & 2025 \\
\hline $\mathrm{M}$ & New Jersey & 1997 & 2002 & 2002 & 2007 & 2011 & 2016 & 2019 & 2022 & 2025 & 2028 \\
\hline M & New Mexico & 1994 & 2004 & 2004 & 2008 & 2012 & 2016 & 2019 & 2022 & 2025 & 2028 \\
\hline A & New York & 1992 & 2002 & 2008 & 2011 & 2011 & 2013 & 2016 & 2019 & 2022 & 2025 \\
\hline $\mathrm{A}$ & North Carolina & 1993 & 2002 & 2006 & 2009 & 2012 & 2013 & 2016 & 2019 & 2022 & 2025 \\
\hline $\mathrm{S}$ & North Dakota & 2002 & 2008 & 2011 & 2011 & 2011 & 2019 & 2022 & 2025 & 2028 & 2031 \\
\hline M & Ohio & 1995 & 2002 & 2005 & 2009 & 2013 & 2016 & 2019 & 2022 & 2025 & 2028 \\
\hline $\mathrm{S}$ & Oklahoma & 2002 & 2008 & 2011 & 2011 & 2011 & 2019 & 2022 & 2025 & 2028 & 2031 \\
\hline A & Oregon & 1992 & 2003 & 2005 & 2008 & 2011 & 2013 & 2016 & 2019 & 2022 & 2025 \\
\hline M & Pennsylvania & 2002 & 2004 & 2004 & 2007 & 2010 & 2016 & 2019 & 2022 & 2025 & 2028 \\
\hline A & Rhode Island & 1997 & 2002 & 2004 & 2007 & 2010 & 2013 & 2016 & 2019 & 2022 & 2025 \\
\hline $\mathrm{M}$ & South Carolina & 1998 & 2001 & 2005 & 2009 & 2013 & 2016 & 2019 & 2022 & 2025 & 2028 \\
\hline $\mathrm{S}$ & South Dakota & 2002 & 2008 & 2013 & 2016 & 2016 & 2019 & 2022 & 2025 & 2028 & 2031 \\
\hline $\mathrm{S}$ & Tennessee & 2002 & 2008 & 2009 & 2011 & 2016 & 2019 & 2022 & 2025 & 2028 & 2031 \\
\hline M & Texas & 2001 & 2001 & 2012 & 2012 & 2012 & 2016 & 2019 & 2022 & 2025 & 2028 \\
\hline $\mathrm{S}$ & Utah & 1995 & 2002 & 2004 & 2007 & 2016 & 2019 & 2022 & 2025 & 2028 & 2031 \\
\hline $\mathrm{S}$ & Vermont & 1998 & 2005 & 2012 & 2012 & 2012 & 2019 & 2022 & 2025 & 2028 & 2031 \\
\hline $\mathrm{A}$ & Virginia & 1993 & 2004 & 2006 & 2008 & 2011 & 2013 & 2016 & 2019 & 2022 & 2025 \\
\hline A & Washington & 1994 & 2002 & 2005 & 2007 & 2011 & 2013 & 2016 & 2019 & 2022 & 2025 \\
\hline $\mathrm{S}$ & West Virginia & 2002 & 2003 & 2006 & 2012 & 2012 & 2019 & 2022 & 2025 & 2028 & 2031 \\
\hline $\mathrm{S}$ & Wisconsin & 1999 & 2008 & 2009 & 2009 & 2016 & 2019 & 2022 & 2025 & 2028 & 2031 \\
\hline $\mathrm{S}$ & Wyoming & 2002 & 2008 & 2013 & 2016 & 2016 & 2019 & 2022 & 2025 & 2028 & 2031 \\
\hline
\end{tabular}


Table 4.7. Residential Energy Code Adoption Assumptions for the Scenario "without BECP"

\begin{tabular}{|c|c|c|c|c|c|c|c|c|c|c|c|}
\hline & & $\begin{array}{l}\text { MEC } \\
92-95 \\
\end{array}$ & $\begin{array}{c}\text { IECC } \\
\mathbf{1 9 9 8 / 2 0 0 0}\end{array}$ & $\begin{array}{c}\text { IECC } \\
2003 \\
\end{array}$ & $\begin{array}{c}\text { IECC } \\
2006 \\
\end{array}$ & $\begin{array}{c}\text { IECC } \\
2009 \\
\end{array}$ & $\begin{array}{c}\text { IECC } \\
2012 \\
\end{array}$ & $\begin{array}{c}\text { IECC } \\
2015 \\
\end{array}$ & $\begin{array}{c}\text { IECC } \\
2018 \\
\end{array}$ & $\begin{array}{c}\text { IECC } \\
2021 \\
\end{array}$ & $\begin{array}{r}\text { IECC } \\
2024 \\
\end{array}$ \\
\hline $\mathrm{S}$ & Alabama & 2005 & 2011 & 2016 & 2016 & 2016 & 2022 & 2025 & 2028 & 2031 & 2034 \\
\hline S & Alaska & 2005 & 2011 & 2016 & 2019 & 2019 & 2022 & 2025 & 2028 & 2031 & 2034 \\
\hline S & Arizona & 2005 & 2011 & 2016 & 2019 & 2019 & 2022 & 2025 & 2028 & 2031 & 2034 \\
\hline $\mathrm{S}$ & Arkansas & 1998 & 2008 & 2008 & 2019 & 2019 & 2022 & 2025 & 2028 & 2031 & 2034 \\
\hline A & California & 1995 & 2004 & 2007 & 2007 & 2011 & 2014 & 2017 & 2020 & 2023 & 2026 \\
\hline $\mathrm{S}$ & Colorado & 1999 & 2008 & 2008 & 2011 & 2019 & 2022 & 2025 & 2028 & 2031 & 2034 \\
\hline M & Connecticut & 2005 & 2011 & 2011 & 2015 & 2018 & 2022 & 2025 & 2028 & 2031 & 2034 \\
\hline M & Delaware & 2002 & 2010 & 2016 & 2016 & 2016 & 2022 & 2025 & 2028 & 2031 & 2034 \\
\hline M & District of Columbia & 2006 & 2010 & 2016 & 2016 & 2016 & 2022 & 2025 & 2028 & 2031 & 2034 \\
\hline A & Florida & 1994 & 2003 & 2006 & 2013 & 2013 & 2014 & 2017 & 2020 & 2023 & 2026 \\
\hline A & Georgia & 1997 & 2005 & 2009 & 2009 & 2012 & 2014 & 2017 & 2020 & 2023 & 2026 \\
\hline $\mathrm{S}$ & Hawaii & 2000 & 2011 & 2013 & 2013 & 2019 & 2022 & 2025 & 2028 & 2031 & 2034 \\
\hline M & Idaho & 2008 & 2009 & 2011 & 2014 & 2017 & 2022 & 2025 & 2028 & 2031 & 2034 \\
\hline A & Illinois & 2003 & 2009 & 2011 & 2011 & 2011 & 2014 & 2017 & 2020 & 2023 & 2026 \\
\hline $\mathrm{S}$ & Indiana & 1996 & 2011 & 2015 & 2015 & 2015 & 2022 & 2025 & 2028 & 2031 & 2034 \\
\hline A & Iowa & 1994 & 2005 & 2005 & 2008 & 2011 & 2014 & 2017 & 2020 & 2023 & 2026 \\
\hline S & Kansas & 2005 & 2011 & 2016 & 2019 & 2019 & 2022 & 2025 & 2028 & 2031 & 2034 \\
\hline M & Kentucky & 2003 & 2011 & 2013 & 2013 & 2018 & 2022 & 2025 & 2028 & 2031 & 2034 \\
\hline S & Louisiana & 2005 & 2011 & 2014 & 2014 & 2019 & 2022 & 2025 & 2028 & 2031 & 2034 \\
\hline M & Maine & 2008 & 2011 & 2011 & 2017 & 2017 & 2022 & 2025 & 2028 & 2031 & 2034 \\
\hline A & Maryland & 1998 & 2002 & 2006 & 2008 & 2011 & 2013 & 2017 & 2020 & 2023 & 2026 \\
\hline A & Massachusetts & 1999 & 2002 & 2009 & 2009 & 2011 & 2014 & 2017 & 2020 & 2023 & 2026 \\
\hline M & Michigan & 2008 & 2014 & 2015 & 2017 & 2017 & 2022 & 2025 & 2028 & 2031 & 2034 \\
\hline S & Minnesota & 2003 & 2011 & 2012 & 2012 & 2019 & 2022 & 2025 & 2028 & 2031 & 2034 \\
\hline S & Mississippi & 2005 & 2011 & 2016 & 2019 & 2019 & 2022 & 2025 & 2028 & 2031 & 2034 \\
\hline $\mathrm{S}$ & Missouri & 2005 & 2011 & 2016 & 2019 & 2019 & 2022 & 2025 & 2028 & 2031 & 2034 \\
\hline M & Montana & 1999 & 2011 & 2011 & 2016 & 2016 & 2022 & 2025 & 2028 & 2031 & 2034 \\
\hline M & Nebraska & 2008 & 2011 & 2011 & 2018 & 2018 & 2022 & 2025 & 2028 & 2031 & 2034 \\
\hline M & Nevada & 2008 & 2011 & 2011 & 2016 & 2018 & 2022 & 2025 & 2028 & 2031 & 2034 \\
\hline A & New Hampshire & 2000 & 2003 & 2008 & 2008 & 2011 & 2014 & 2017 & 2020 & 2023 & 2026 \\
\hline M & New Jersey & 2003 & 2008 & 2008 & 2013 & 2017 & 2022 & 2025 & 2028 & 2031 & 2034 \\
\hline M & New Mexico & 2000 & 2010 & 2010 & 2014 & 2018 & 2022 & 2025 & 2028 & 2031 & 2034 \\
\hline A & New York & 1993 & 2003 & 2009 & 2012 & 2012 & 2014 & 2017 & 2020 & 2023 & 2026 \\
\hline A & North Carolina & 1994 & 2003 & 2007 & 2010 & 2013 & 2014 & 2017 & 2020 & 2023 & 2026 \\
\hline S & North Dakota & 2005 & 2011 & 2014 & 2014 & 2014 & 2022 & 2025 & 2028 & 2031 & 2034 \\
\hline M & Ohio & 2001 & 2008 & 2011 & 2015 & 2019 & 2022 & 2025 & 2028 & 2031 & 2034 \\
\hline $\mathrm{S}$ & Oklahoma & 2005 & 2011 & 2014 & 2014 & 2014 & 2022 & 2025 & 2028 & 2031 & 2034 \\
\hline A & Oregon & 1993 & 2004 & 2006 & 2009 & 2012 & 2014 & 2017 & 2020 & 2023 & 2026 \\
\hline M & Pennsylvania & 2008 & 2010 & 2010 & 2013 & 2016 & 2022 & 2025 & 2028 & 2031 & 2034 \\
\hline A & Rhode Island & 1998 & 2003 & 2005 & 2008 & 2011 & 2014 & 2017 & 2020 & 2023 & 2026 \\
\hline M & South Carolina & 2004 & 2007 & 2011 & 2015 & 2019 & 2022 & 2025 & 2028 & 2031 & 2034 \\
\hline $\mathrm{S}$ & South Dakota & 2005 & 2011 & 2016 & 2019 & 2019 & 2022 & 2025 & 2028 & 2031 & 2034 \\
\hline $\mathrm{S}$ & Tennessee & 2005 & 2011 & 2012 & 2014 & 2019 & 2022 & 2025 & 2028 & 2031 & 2034 \\
\hline M & Texas & 2007 & 2007 & 2018 & 2018 & 2018 & 2022 & 2025 & 2028 & 2031 & 2034 \\
\hline S & Utah & 1998 & 2005 & 2007 & 2010 & 2019 & 2022 & 2025 & 2028 & 2031 & 2034 \\
\hline S & Vermont & 2001 & 2008 & 2015 & 2015 & 2015 & 2022 & 2025 & 2028 & 2031 & 2034 \\
\hline A & Virginia & 1994 & 2005 & 2007 & 2009 & 2012 & 2014 & 2017 & 2020 & 2023 & 2026 \\
\hline A & Washington & 1995 & 2003 & 2006 & 2008 & 2012 & 2014 & 2017 & 2020 & 2023 & 2026 \\
\hline S & West Virginia & 2005 & 2006 & 2009 & 2015 & 2015 & 2022 & 2025 & 2028 & 2031 & 2034 \\
\hline S & Wisconsin & 2002 & 2011 & 2012 & 2012 & 2019 & 2022 & 2025 & 2028 & 2031 & 2034 \\
\hline $\mathrm{S}$ & Wyoming & 2005 & 2011 & 2016 & 2019 & 2019 & 2022 & 2025 & 2028 & 2031 & 2034 \\
\hline
\end{tabular}




\subsection{Residential Energy Code Compliance}

The logic applied in developing residential energy code compliance assumptions was similar to that used for the commercial compliance assumptions. It is the relative difference in compliance rates between the two scenarios, rather than the absolute level of compliance, that drives the estimation. Very little comparable information exists on state-by-state compliance rates. Therefore, uniform, national compliance rates parameterized based on the review of the available compliance studies were applied for the "with BECP" scenario. These compliance rates are presented in Table 4.8.

Table 4.8. Residential Code Compliance Assumptions for "With BECP" Scenario

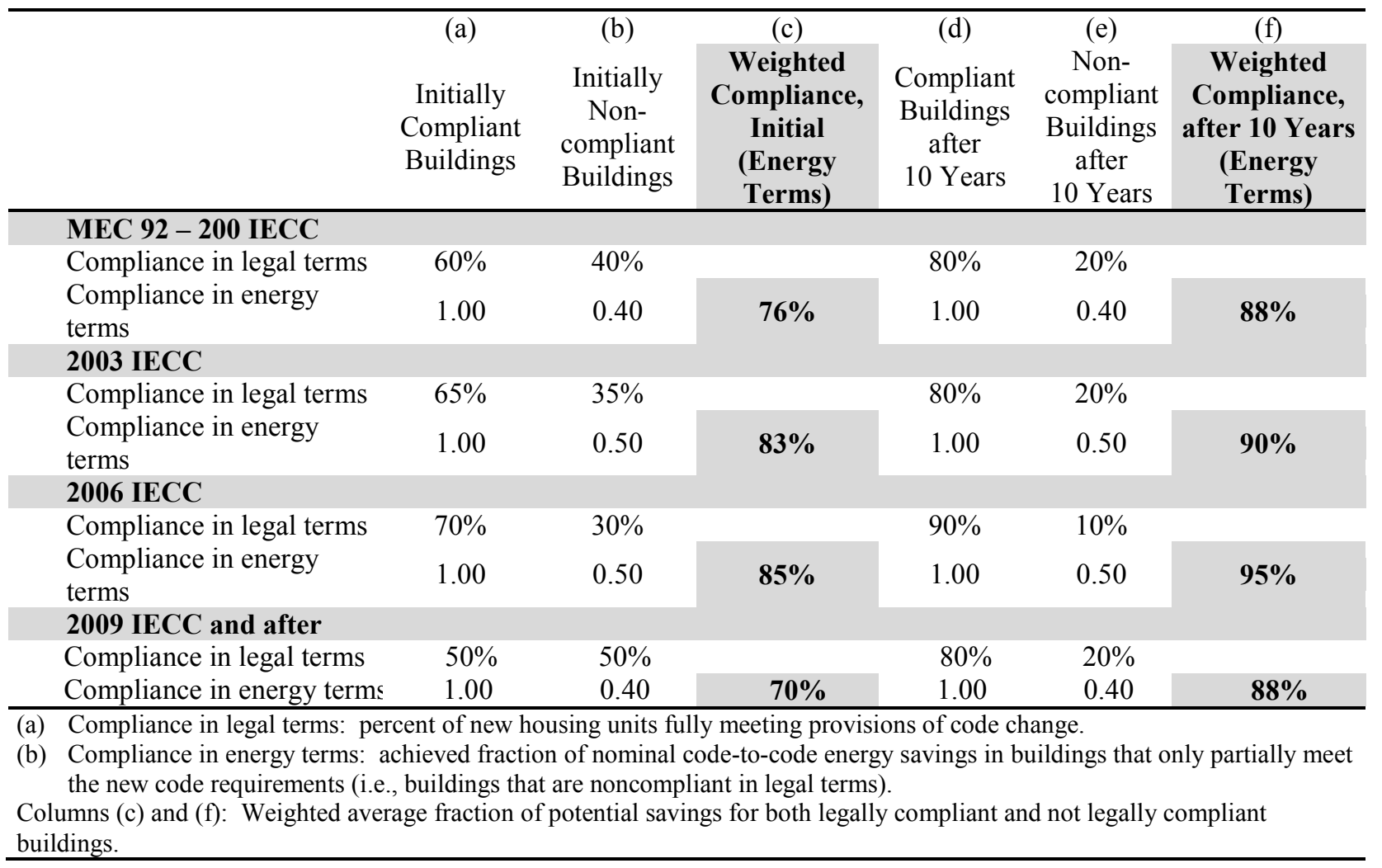

Compliance rates presented in the table above apply to all modeled end-use groups uniformly. Similar logic discussed in Section 3.4 is applied here. Compliance assumptions for the scenario "without BECP" were developed based on the state categorization. The percentage point difference in compliance between scenarios "with BECP" and "without BECP" is presented in Table 4.9.

Table 4.9. Percent Point Difference between Residential Compliance Levels "with BECP" and "without BECP" Scenarios

\begin{tabular}{lcc}
\hline & $\begin{array}{c}\text { Before 2006 } \\
\text { IECC }\end{array}$ & $\begin{array}{c}\text { 2006 IECC } \\
\text { and after }\end{array}$ \\
\hline Aggressive & $5 \%$ & $10 \%$ \\
Moderate & $20 \%$ & $30 \%$ \\
Slow & $10 \%$ & $20 \%$ \\
\hline
\end{tabular}




\subsection{Estimated Benefits of the Residential BECP Activities}

This analysis assumed that BECP residential energy code efforts improve code-to-code energy efficiency by supporting code development, accelerating the adoption of the most recent residential building energy codes (or equivalent), and increasing compliance with the code provisions. Note that energy savings achieved in California, Washington, Oregon, and Florida were totally or partially removed from the BECP benefits calculation as presented in Table 4.10. ${ }^{16}$

Table 4.10. States Excluded from the BECP Residential Benefits Calculation

\begin{tabular}{ll}
\hline State & \multicolumn{1}{c}{ Residential } \\
\hline California & All years excluded \\
Florida & Excluded 1992-2011 \\
Oregon & All years excluded \\
Washington & Excluded 1992-2012 \\
\hline
\end{tabular}

Following the analysis methodology used by DOE's Appliance and Equipment Standards Program, site energy savings were first converted to source terms, which includes energy used in generation, transmission, and distribution (primary energy). Energy used further "upstream" in the mining, processing, and transportation of fuels was calculated using the NIA PLUS model (Coughlin 2012) ${ }^{17}$ and added to the primary energy savings to yield full-fuel-cycle (FFC) energy savings. Emissions savings and emissions monetization were also calculated using the NIA PLUS model. Detailed explanations of technical assumptions, scalars, and cost rates underlying this set of calculations are available (10 CFR 429 and 430).

The remainder of this section discusses estimated site and primary energy savings, FFC savings, emissions savings, emissions monetization, and consumer benefits.

BECP historical and projected energy savings (site or delivered energy) are presented in Table 4.11. For the historical portion of the Program savings, cumulative site energy savings between 1992 and 2012 totaled $719 \mathrm{TBtu}$, with the annual site energy savings being approximately $81 \mathrm{TBtu}$ at the end of 2012 .

The amount of annual savings ( $81 \mathrm{TBtu}$ ) in 2012 from the pre-2012 construction is assumed to continue from 2013 until 2040 because of the implicit assumption that the average expected lifetime of a residential building exceeds the forecast horizon. This portion comprises the first stream of savings. Cumulative savings from this stream equal 2.3 quads in 2040.

Projected annual site savings from future code activities and construction equal 458 TBtu in 2040 and cumulative savings from this second savings stream equal 7.2 quads from 2013 through 2040.

When the stream of future savings from past construction and the stream of future savings for future construction are combined, the annual projected savings equal 539 TBtu by 2040. Cumulative savings from residential BECP activities reach 10.2 quads by 2040 .

\footnotetext{
${ }^{16} \mathrm{CA}$ and OR have been excluded from this analysis due to their history of developing their own advanced statespecific residential code without direct assistance from BECP's tools or resources. WA and FL have been partially excluded due to their history of adopting their own state-specific codes without direct assistance from BECP's tools or resources; however, WA and FL received technical assistance within the past 3 years to implement their statespecific codes into REScheck. WA: implemented its residential code into REScheck in 2013. FL: implemented its residential state code into REScheck in 2011.

${ }^{17}$ Coughlin, K., Calculation of Full Fuel Cycle Multipliers for Energy Use in Buildings. LBNL Paper, 2012.
} 
Table 4.11. BECP Residential Site Energy Savings (TBtu)

\begin{tabular}{|c|c|c|c|c|c|c|c|}
\hline & $\begin{array}{c}\text { Electricity } \\
\text { TBtu }\end{array}$ & $\begin{array}{c}\text { Natural Gas } \\
\text { TBtu }\end{array}$ & $\begin{array}{c}\text { Heating Oil } \\
\text { TBtu }\end{array}$ & $\begin{array}{c}\text { Total, Annual } \\
\text { TBtu }\end{array}$ & $\begin{array}{c}\text { Total, Cumulative } \\
\text { TBtu }\end{array}$ & & \\
\hline 1992 & 0.10 & 0.26 & 0.02 & 0.4 & 0.4 & & \\
\hline 1993 & 0.68 & 0.76 & 0.03 & 1.5 & 1.9 & & \\
\hline 1994 & 0.88 & 1.18 & 0.03 & 2.1 & 3.9 & & \\
\hline 1995 & 1.31 & 2.07 & 0.04 & 3.4 & 7.4 & & \\
\hline 1996 & 2.09 & 3.13 & 0.05 & 5.3 & 13 & & \\
\hline 1997 & 2.90 & 4.41 & 0.08 & 7.4 & 20 & & \\
\hline 1998 & 3.72 & 5.72 & 0.16 & 10 & 30 & & \\
\hline 1999 & 4.61 & 7.18 & 0.25 & 12 & 42 & & \\
\hline 2000 & 5.62 & 8.82 & 0.32 & 15 & 56 & & \\
\hline 2001 & 7.47 & 10.71 & 0.42 & 19 & 75 & & \\
\hline 2002 & 11 & 15 & 0.58 & 27 & 102 & & \\
\hline 2003 & 14 & 19 & 0.69 & 34 & 136 & & \\
\hline 2004 & 19 & 23 & 0.84 & 43 & 179 & & \\
\hline 2005 & 22 & 28 & 1.03 & 51 & 229 & & \\
\hline 2006 & 25 & 32 & 1.20 & 58 & 288 & & \\
\hline 2007 & 27 & 35 & 1.35 & 63 & 351 & & \\
\hline 2008 & 29 & 37 & 1.45 & 68 & 419 & & \\
\hline 2009 & 31 & 39 & 1.51 & 71 & 490 & & \\
\hline 2010 & 32 & 40 & 1.59 & 73 & 563 & & \\
\hline 2011 & 33 & 41 & 1.65 & 75 & 638 & \multirow{2}{*}{\multicolumn{2}{|c|}{$\begin{array}{c}\text { Annual } \\
\text { Cumulative } \\
\text { Post } 2012 \text { construction only }\end{array}$}} \\
\hline 2012 & 36 & 43 & 1.73 & 81 & 719 & & \\
\hline 2013 & 41 & 48 & 1.94 & 91 & 811 & 10 & 10 \\
\hline 2014 & 46 & 52 & 2.10 & 99 & 910 & 18 & 29 \\
\hline 2015 & 51 & 56 & 2.28 & 109 & 1,019 & 28 & 56 \\
\hline 2016 & 61 & 67 & 2.72 & 131 & 1,150 & 50 & 106 \\
\hline 2017 & 71 & 77 & 3.05 & 151 & 1,300 & 70 & 176 \\
\hline 2018 & 79 & 86 & 3.38 & 169 & 1,469 & 87 & 263 \\
\hline 2019 & 91 & 102 & 3.82 & 197 & 1,666 & 116 & 379 \\
\hline 2020 & 103 & 118 & 4.22 & 224 & 1,891 & 143 & 523 \\
\hline 2021 & 114 & 133 & 4.61 & 251 & 2,142 & 170 & 693 \\
\hline 2022 & 124 & 146 & 4.94 & 274 & 2,416 & 193 & 886 \\
\hline 2023 & 133 & 158 & 5.25 & 297 & 2,713 & 216 & 1,102 \\
\hline 2024 & 143 & 171 & 5.55 & 319 & 3,032 & 238 & 1,340 \\
\hline 2025 & 151 & 180 & 5.79 & 337 & 3,369 & 256 & 1,596 \\
\hline 2026 & 159 & 188 & 6.01 & 353 & 3,723 & 272 & 1,868 \\
\hline 2027 & 167 & 197 & 6.22 & 370 & 4,092 & 289 & 2,157 \\
\hline 2028 & 174 & 205 & 6.41 & 385 & 4,477 & 304 & 2,461 \\
\hline 2029 & 181 & 213 & 6.61 & 401 & 4,878 & 320 & 2,780 \\
\hline 2030 & 188 & 221 & 6.80 & 416 & 5,294 & 335 & 3,115 \\
\hline 2031 & 195 & 228 & 6.97 & 430 & 5,724 & 349 & 3,464 \\
\hline 2032 & 201 & 235 & 7.13 & 444 & 6,168 & 363 & 3,827 \\
\hline 2033 & 208 & 243 & 7.29 & 457 & 6,625 & 376 & 4,203 \\
\hline 2034 & 213 & 249 & 7.43 & 469 & 7,094 & 388 & 4,591 \\
\hline 2035 & 219 & 255 & 7.57 & 481 & 7,575 & 400 & 4,991 \\
\hline 2036 & 224 & 261 & 7.71 & 493 & 8,068 & 412 & 5,403 \\
\hline 2037 & 230 & 267 & 7.84 & 504 & 8,572 & 423 & 5,826 \\
\hline 2038 & 235 & 273 & 7.97 & 516 & 9,088 & 435 & 6,261 \\
\hline 2039 & 240 & 279 & 8.09 & 528 & 9,616 & 447 & 6,708 \\
\hline 2040 & 246 & 285 & 8.21 & 539 & 10,155 & 458 & 7,166 \\
\hline
\end{tabular}


Detailed estimates for primary energy, upstream supply chain, and FFC energy savings are presented in Table 4.12. Energy and cost savings from the BECP residential activities are summarized in Table 4.13. Accumulated primary energy savings from residential energy code activities over the period of 1992-2012 equal 1.3 quads, with annual savings reaching 0.15 quads in 2012 (Table 4.13). The amount of annual savings ( 0.15 quads in 2012) from the pre-2012 construction was assumed to continue from 2013 until 2040 (projected savings, Stream 1). Cumulative savings from this stream equal 4.2 quads for 2013-2040 (Table 4.13).

Projected annual primary savings from future code activities (projected savings, Stream 2) equal 0.7 quad in 2040. Cumulative savings from this second savings stream equal approximately 11.7 quads for 2013-2040. When the stream of future primary savings from past construction and the stream of future primary savings from future code activities are combined (Stream $1+$ Stream 2), the annual projected primary savings equal 0.9 quad by 2040 . Cumulative projected primary savings from residential BECP activities between 2013 and 2040 equal 15.9 quads by 2040 .

Combining 1.3 quads of cumulative historical savings (1992-2012) with 15.9 quads of cumulative projected savings (2013-2040) brings the total BECP primary energy savings from residential code activities to 17.2 quads for 1992-2040 (not shown in the table).

FFC energy savings from residential energy code activities over the 1992-2012 periods equal 1.35 quads, with annual savings reaching 155 TBtu in 2012. The amount of annual savings from the pre2012 construction (155 TBtu) continue from 2013 until 2040 (projected savings, Stream 1). Cumulative savings from this stream (not shown in the table) equal 4.3 quads for 2013-2040.

Projected annual FFC savings from future code activities (projected savings, Stream 2) equal 0.8 quad in 2040. Cumulative FFC savings from this second savings stream equal 12.2 quads for 2013-2040.

When the stream of future savings from past construction and the stream of future savings from future code activities are combined (Stream $1+$ Stream 2), the annual projected future savings equal 0.9 quads by 2040. Cumulative projected FFC savings from residential BECP activities between 2013 and 2040 reach 16.5 quads by 2040 .

Combining 1.3 quads of cumulative historical savings with 16.5 quads of cumulative projected savings, brings the total BECP FFC savings from residential code activities to 17.9 quads for 1992-2040.

Historical and projected site energy savings were then used to calculate energy cost savings. For 1992-2012 savings, EIA historical electricity and natural gas prices for the residential sector were converted to 2012 dollars based on the GDP chain-type price index ${ }^{18}$ to calculate the annual and cumulative cost savings.

As shown in Table 4.13, annual historical cost savings reach $\$ 1.7$ billion in 2012 and cumulative savings between 1992 and 2012 equal $\$ 15.6$ billion.

\footnotetext{
${ }^{18}$ Federal Reserve Economic Data, Gross Domestic Product: Chain-type Price Index (GDPCTPI), Index 2005=100, Annual, Seasonally Adjusted. Economic Research Division, Federal Reserve Bank of St. Louis, http://research.stlouisfed.org/fred2
} 
Table 4.12. BECP Residential Primary and Full-Fuel-Cycle Energy Savings (TBtu)

\begin{tabular}{|c|c|c|c|c|c|c|}
\hline & Primary & $\begin{array}{c}\text { Upstream } \\
\text { Supply Chain }\end{array}$ & $\begin{array}{c}\text { FFC, } \\
\text { Annual }\end{array}$ & $\begin{array}{c}\text { FFC, } \\
\text { Cumulative }\end{array}$ & & \\
\hline 1992 & 0.6 & 0.0 & 0.6 & 0.6 & & \\
\hline 1993 & 2.7 & 0.1 & 2.8 & 3.5 & & \\
\hline 1994 & 3.7 & 0.2 & 3.9 & 7 & & \\
\hline 1995 & 6 & 0.3 & 6 & 13 & & \\
\hline 1996 & 9 & 0.4 & 10 & 23 & & \\
\hline 1997 & 13 & 0.6 & 13 & 36 & & \\
\hline 1998 & 17 & 0.8 & 17 & 54 & & \\
\hline 1999 & 21 & 1.0 & 22 & 75 & & \\
\hline 2000 & 25 & 1.2 & 26 & 102 & & \\
\hline 2001 & 32 & 1.5 & 34 & 136 & & \\
\hline 2002 & 47 & 2.2 & 50 & 185 & & \\
\hline 2003 & 61 & 2.7 & 63 & 249 & & \\
\hline 2004 & 77 & 3.4 & 81 & 330 & & \\
\hline 2005 & 92 & 4.0 & 96 & 425 & & \\
\hline 2006 & 106 & 4.6 & 110 & 536 & & \\
\hline 2007 & 114 & 5.0 & 119 & 655 & & \\
\hline 2008 & 122 & 5.4 & 127 & 782 & & \\
\hline 2009 & 127 & 5.6 & 133 & 915 & & \\
\hline 2010 & 132 & 5.8 & 138 & 1,053 & \multicolumn{2}{|c|}{ Post 2012 construction } \\
\hline 2011 & 136 & 5.9 & 142 & 1,195 & FFC, & FFC, \\
\hline 2012 & 149 & 6.4 & 155 & 1,350 & Annual & Cumulative \\
\hline 2013 & 168 & 7 & 175 & 1,525 & 20 & 20 \\
\hline 2014 & 184 & 8 & 192 & 1,717 & 37 & 57 \\
\hline 2015 & 203 & 8 & 211 & 1,928 & 56 & 113 \\
\hline 2016 & 245 & 10 & 255 & 2,183 & 100 & 212 \\
\hline 2017 & 282 & 11 & 293 & 2,476 & 138 & 351 \\
\hline 2018 & 315 & 13 & 328 & 2,803 & 173 & 523 \\
\hline 2019 & 367 & 15 & 381 & 3,185 & 227 & 750 \\
\hline 2020 & 415 & 17 & 432 & 3,617 & 277 & 1,027 \\
\hline 2021 & 434 & 19 & 453 & 4,069 & 298 & 1,324 \\
\hline 2022 & 473 & 21 & 494 & 4,563 & 339 & 1,663 \\
\hline 2023 & 511 & 22 & 533 & 5,096 & 378 & 2,041 \\
\hline 2024 & 549 & 24 & 573 & 5,669 & 418 & 2,459 \\
\hline 2025 & 580 & 25 & 605 & 6,274 & 450 & 2,909 \\
\hline 2026 & 584 & 26 & 610 & 6,884 & 455 & 3,364 \\
\hline 2027 & 611 & 27 & 638 & 7,522 & 483 & 3,848 \\
\hline 2028 & 637 & 28 & 666 & 8,188 & 511 & 4,358 \\
\hline 2029 & 663 & 29 & 692 & 8,880 & 538 & 4,896 \\
\hline 2030 & 689 & 30 & 720 & 9,600 & 565 & 5,460 \\
\hline 2031 & 702 & 32 & 734 & 10,334 & 579 & 6,039 \\
\hline 2032 & 725 & 33 & 757 & 11,091 & 602 & 6,642 \\
\hline 2033 & 748 & 34 & 781 & 11,872 & 626 & 7,268 \\
\hline 2034 & 767 & 34 & 801 & 12,674 & 646 & 7,914 \\
\hline 2035 & 786 & 35 & 822 & 13,495 & 667 & 8,581 \\
\hline 2036 & 806 & 36 & 842 & 14,337 & 687 & 9,268 \\
\hline 2037 & 825 & 37 & 862 & 15,199 & 707 & 9,975 \\
\hline 2038 & 844 & 38 & 882 & 16,081 & 727 & 10,702 \\
\hline 2039 & 864 & 38 & 902 & 16,983 & 747 & 11,449 \\
\hline 2040 & 883 & 39 & 922 & 17,905 & 767 & 12,216 \\
\hline
\end{tabular}


Table 4.13. Summary of Energy and Cost Savings from the BECP Residential Energy Code Activities

\begin{tabular}{lcccc}
\hline & $\begin{array}{c}\text { Site Energy } \\
\text { Savings, } \\
\text { TBtu }\end{array}$ & $\begin{array}{c}\text { Primary Energy } \\
\text { Savings, } \\
\text { TBtu }\end{array}$ & $\begin{array}{c}\text { FFC Energy } \\
\text { Savings, } \\
\text { TBtu }\end{array}$ & $\begin{array}{c}\text { Energy Cost } \\
\text { Savings NPV, } \\
\text { billion 2012\$ }\end{array}$ \\
\hline Historical & & & & \\
$\quad$ Annual in 2012 & 81 & 149 & 155 & 1.7 \\
$\quad$ Cumulative 1992-2012 & 719 & 1,293 & 1,350 & 15.6 \\
\hline $\begin{array}{l}\text { Projected, Stream 1 } \\
\text { Annual in 2040 }\end{array}$ & 81 & 149 & 155 & 0.3 \\
$\quad$ Cumulative 2013-2040 & 2,270 & 4,160 & 4,339 & 23.8 \\
\hline $\begin{array}{l}\text { Projected, Stream 2 } \\
\text { Annual in 2040 }\end{array}$ & 458 & & & \\
$\quad$ Cumulative 2013-2040 & 7,166 & 734 & 767 & 2.0 \\
\hline BECP Total & & 11,700 & 12,216 & 55.8 \\
$\quad$ Annual in 2040 & 539 & 883 & & \\
$\quad$ Cumulative 1992-2040 & 10,155 & 17,153 & 922 & 2.3 \\
\hline
\end{tabular}

For projected savings, the NIA PLUS model was used to calculate the NPV of the future cost savings. AEO 2013 reference case prices were converted to 2012 dollars and a 7\% discount rate was applied. The NPV of annual projected savings in 2040 for Stream 1 equals $\$ 0.3$ billion. The NPV of cumulative cost saving for Stream 1 equals $\$ 23.8$ billion. The NPV of annual projected savings in 2040 for Stream 2 equals almost $\$ 2$ billion. The NPV of cumulative cost savings for Stream 2 equals $\$ 55.8$ billion. Combined, the NPV of projected energy cost savings equals almost $\$ 80$ billion. Total accumulated cost savings to consumers from the BECP residential energy code activities for 1992-2040 equal \$95.2 billion.

Emissions savings were estimated for $\mathrm{CO}_{2}, \mathrm{NO}_{x}, \mathrm{Hg}, \mathrm{N}_{2} \mathrm{O}, \mathrm{CH}_{4}$, and $\mathrm{SO}_{2}$. Detailed annual results for the emissions savings are included in Table 4.14. A summary of historical and projected emissions savings is presented in Table 4.15 .

The cumulative emissions reduction between 1992 and 2040 includes 1.3 billion metric tons (Mt) of $\mathrm{CO}_{2}, 1.8$ million tons of $\mathrm{NO}_{\mathrm{x}}, 2.8$ tons of $\mathrm{Hg}$, and 1.1 million tons of $\mathrm{SO}_{2}$.

The value of the $\mathrm{CO}_{2}$ emissions reduction is $\$ 0.7$ to 2.4 billion (2012\$) based on 2013 domestic social carbon values and a $5 \%$ discount rate, or about 10.6 billion based on global SCC, while $\mathrm{NO}_{\mathrm{x}}$ savings contribute at least another $\$ 0.4$ billion (at $\$ 468$ per ton in $2012 \$$ ). Energy cost savings presented in Table 4.13, combined with monetized emissions savings presented in Table 4.16, capture consumer benefits to the nation from the residential BECP activities. Combined consumer benefits from residential BECP activities are shown in Table 4.17. Depending on the price of $\mathrm{CO}_{2}$ and $\mathrm{NO}_{\mathrm{x}}$, the NPV of overall consumer benefits can range between $\$ 106$ and 235 billion (2012\$). Out of that total, the energy cost savings constitute $\$ 95$ billion (2012\$). 
Table 4.14. Annual Emissions Savings from the BECP Residential Activities, Full-Fuel-Cycle

\begin{tabular}{|c|c|c|c|c|c|c|c|c|}
\hline & $\begin{array}{l}\mathrm{CO}_{2} \\
m m t\end{array}$ & $\begin{array}{c}\mathrm{NO}_{\mathrm{x}} \\
\boldsymbol{k t}\end{array}$ & $\begin{array}{l}\mathrm{Hg} \\
\text { ton }\end{array}$ & $\begin{array}{c}\mathrm{N}_{2} \mathrm{O} \\
k t\end{array}$ & $\begin{array}{c}\mathrm{N}_{2} \mathrm{O} \\
m m t C \mathrm{O}_{2} e q\end{array}$ & $\begin{array}{c}\mathrm{CH}_{4} \\
k t\end{array}$ & $\begin{array}{c}\mathrm{CH}_{4} \\
m m t \mathrm{CO}_{2} e q\end{array}$ & $\begin{array}{c}\mathrm{SO}_{2} \\
k t\end{array}$ \\
\hline 1992 & 0.0 & 0.1 & 0.00 & 0.00 & 0.00 & 0.26 & 0.0 & 0.0 \\
\hline 1993 & 0.2 & 0.4 & 0.00 & 0.00 & 0.00 & 1.00 & 0.0 & 0.2 \\
\hline 1994 & 0.3 & 0.6 & 0.00 & 0.00 & 0.00 & 1.43 & 0.0 & 0.3 \\
\hline 1995 & 0.4 & 0.9 & 0.00 & 0.00 & 0.00 & 2.36 & 0.1 & 0.5 \\
\hline 1996 & 0.7 & 1.5 & 0.00 & 0.01 & 0.00 & 3.64 & 0.1 & 0.7 \\
\hline 1997 & 0.9 & 2.1 & 0.00 & 0.01 & 0.00 & 5.08 & 0.1 & 1.0 \\
\hline 1998 & 1.2 & 2.7 & 0.00 & 0.01 & 0.00 & 7 & 0.2 & 1.3 \\
\hline 1999 & 1.5 & 3.3 & 0.00 & 0.01 & 0.00 & 8 & 0.2 & 1.6 \\
\hline 2000 & 1.8 & 4.1 & 0.00 & 0.02 & 0.01 & 10 & 0.3 & 2.0 \\
\hline 2001 & 2.3 & 5.3 & 0.00 & 0.02 & 0.01 & 13 & 0.3 & 2.6 \\
\hline 2002 & 3.4 & 7.7 & 0.01 & 0.03 & 0.01 & 18 & 0.5 & 3.9 \\
\hline 2003 & 4.4 & 9.9 & 0.01 & 0.04 & 0.01 & 23 & 0.6 & 5.1 \\
\hline 2004 & 5.6 & 12.7 & 0.01 & 0.06 & 0.02 & 29 & 0.7 & 6.6 \\
\hline 2005 & 6.6 & 15.0 & 0.01 & 0.07 & 0.02 & 35 & 0.9 & 7.8 \\
\hline 2006 & 7.6 & 17.3 & 0.01 & 0.08 & 0.02 & 40 & 1.0 & 9.0 \\
\hline 2007 & 8.2 & 18.6 & 0.01 & 0.08 & 0.02 & 43 & 1.1 & 9.6 \\
\hline 2008 & 8.8 & 19.9 & 0.02 & 0.09 & 0.03 & 46 & 1.2 & 10.3 \\
\hline 2009 & 9.2 & 20.8 & 0.02 & 0.09 & 0.03 & 48 & 1.2 & 10.8 \\
\hline 2010 & 9.5 & 21.6 & 0.02 & 0.10 & 0.03 & 50 & 1.3 & 11.2 \\
\hline 2011 & 9.8 & 22.3 & 0.02 & 0.10 & 0.03 & 51 & 1.3 & 11.5 \\
\hline 2012 & 10.8 & 24.5 & 0.02 & 0.10 & 0.03 & 55 & 1.4 & 12.7 \\
\hline 2013 & 12.2 & 27.5 & 0.02 & 0.12 & 0.03 & 60 & 1.5 & 14.5 \\
\hline 2014 & 13.3 & 29.8 & 0.02 & 0.12 & 0.04 & 65 & 1.6 & 15.8 \\
\hline 2015 & 14.7 & 32.9 & 0.02 & 0.13 & 0.04 & 72 & 1.8 & 17.2 \\
\hline 2016 & 17.8 & 39.8 & 0.03 & 0.16 & 0.05 & 86 & 2.2 & 20.9 \\
\hline 2017 & 20.4 & 45.7 & 0.03 & 0.18 & 0.05 & 99 & 2.5 & 24.0 \\
\hline 2018 & 22.8 & 50.9 & 0.04 & 0.21 & 0.06 & 110 & 2.7 & 26.8 \\
\hline 2019 & 26.6 & 59.2 & 0.05 & 0.24 & 0.07 & 128 & 3.2 & 31.0 \\
\hline 2020 & 30.0 & 66.9 & 0.05 & 0.27 & 0.08 & 145 & 3.6 & 34.9 \\
\hline 2021 & 30.4 & 34.9 & 0.06 & 0.30 & 0.09 & 162 & 4.0 & 41.8 \\
\hline 2022 & 33.2 & 37.8 & 0.06 & 0.33 & 0.10 & 176 & 4.4 & 45.5 \\
\hline 2023 & 35.8 & 40.8 & 0.07 & 0.36 & 0.11 & 189 & 4.7 & 49.0 \\
\hline 2024 & 38.4 & 43.6 & 0.07 & 0.38 & 0.11 & 203 & 5.1 & 52.5 \\
\hline 2025 & 40.6 & 45.8 & 0.08 & 0.41 & 0.12 & 213 & 5.3 & 55.6 \\
\hline 2026 & 44.4 & 52.6 & 0.08 & 0.43 & 0.13 & 224 & 5.6 & 25.3 \\
\hline 2027 & 46.5 & 54.9 & 0.08 & 0.45 & 0.13 & 234 & 5.8 & 26.5 \\
\hline 2028 & 48.5 & 57.1 & 0.09 & 0.46 & 0.14 & 244 & 6.1 & 27.7 \\
\hline 2029 & 50.5 & 59.3 & 0.09 & 0.48 & 0.14 & 253 & 6.3 & 28.8 \\
\hline 2030 & 52.5 & 61.6 & 0.09 & 0.50 & 0.15 & 264 & 6.6 & 30.0 \\
\hline 2031 & 58.9 & 68.4 & 0.14 & 0.52 & 0.15 & 273 & 6.8 & 40.2 \\
\hline 2032 & 60.8 & 70.7 & 0.15 & 0.53 & 0.16 & 282 & 7.0 & 41.6 \\
\hline 2033 & 62.8 & 73.0 & 0.15 & 0.55 & 0.16 & 291 & 7.3 & 42.9 \\
\hline 2034 & 64.4 & 74.7 & 0.16 & 0.56 & 0.17 & 298 & 7.4 & 44.0 \\
\hline 2035 & 66.0 & 76.4 & 0.16 & 0.58 & 0.17 & 305 & 7.6 & 45.1 \\
\hline 2036 & 67.6 & 77.5 & 0.16 & 0.59 & 0.18 & 312 & 7.8 & 46.3 \\
\hline 2037 & 69.3 & 79.3 & 0.17 & 0.60 & 0.18 & 319 & 8.0 & 47.4 \\
\hline 2038 & 70.9 & 81.1 & 0.17 & 0.62 & 0.18 & 327 & 8.2 & 48.5 \\
\hline 2039 & 72.5 & 82.8 & 0.18 & 0.63 & 0.19 & 334 & 8.4 & 49.7 \\
\hline 2040 & 74.1 & 84.6 & 0.18 & 0.64 & 0.19 & 342 & 8.5 & 50.8 \\
\hline Total & 1,339 & 1,821 & 2.8 & 12.3 & 3.66 & 6,497 & 162 & 1,133 \\
\hline
\end{tabular}


Table 4.15. Summary of Emissions Savings from the BECP Residential Energy Code Activities

\begin{tabular}{|c|c|c|c|c|c|c|c|c|c|}
\hline & & $\begin{array}{c}\mathrm{CO}_{2} \\
\mathrm{mmt}\end{array}$ & $\begin{array}{c}\mathbf{N O}_{\mathbf{x}} \\
\mathbf{k t}\end{array}$ & $\begin{array}{l}\mathrm{Hg} \\
\text { ton }\end{array}$ & $\begin{array}{c}\mathrm{N}_{2} \mathrm{O} \\
\mathrm{kt}\end{array}$ & $\begin{array}{c}\mathrm{N}_{2} \mathrm{O} \\
\text { mmt } \mathrm{CO}_{2} \mathrm{eq}\end{array}$ & $\begin{array}{c}\mathrm{CH}_{4} \\
\mathrm{kt}\end{array}$ & $\begin{array}{c}\mathrm{CH}_{4} \\
\mathrm{mmt} \mathrm{CO} \mathrm{O}_{2} \mathrm{eq}\end{array}$ & $\begin{array}{c}\mathrm{SO}_{2} \\
\mathrm{kt}\end{array}$ \\
\hline \multicolumn{10}{|l|}{ Historical } \\
\hline & Annual in 2012 & 11 & 24 & 0.0 & 0.1 & 0.0 & 55 & 1.4 & 13 \\
\hline & Cumulative 1992-2012 & 93 & 211 & 0.2 & 0.9 & 0.3 & 490 & 12 & 109 \\
\hline \multicolumn{10}{|c|}{ Projected, Stream 1} \\
\hline & Annual in 2040 & 11 & 24 & 0.0 & 0.1 & 0.0 & 55 & 1.4 & 13 \\
\hline & Cumulative 2013-2040 & 301 & 685 & 0.5 & 2.9 & 0.9 & 1,529 & 38 & 355 \\
\hline \multicolumn{10}{|c|}{ Projected, Stream 2} \\
\hline & Annual in 2040 & 63 & 60 & 0.2 & 0.5 & 0.2 & 287 & 7.2 & 38 \\
\hline & Cumulative 2013-2040 & 945 & 925 & 2.1 & 8.5 & 2.5 & 4,479 & 112 & 669 \\
\hline \multicolumn{10}{|l|}{ BECP Total } \\
\hline & Annual in 2040 & 74 & 85 & 0.2 & 0.6 & 0.2 & 342 & 9 & 51 \\
\hline & Cumulative 1992-2040 & 1,339 & 1,821 & 2.8 & 12.3 & 3.7 & 6,497 & 162 & 1,133 \\
\hline
\end{tabular}

Table 4.16. National Cumulative Benefits of the BECP Residential Activities, 1992-2040

\begin{tabular}{|c|c|c|}
\hline \multicolumn{3}{|l|}{ Energy Savings } \\
\hline Primary & quads & 17.2 \\
\hline Upstream & quads & 0.8 \\
\hline Full-Fuel-Cycle (total) & quads & 17.9 \\
\hline \multicolumn{3}{|l|}{ Economic Impacts } \\
\hline Historical Energy Cost Savings & billion $2012 \$$ & 15 \\
\hline Projected Energy Cost Savings & billion $2012 \$$ & 80 \\
\hline Total Energy Cost Savings & billion $2012 \$$ & 95 \\
\hline \multicolumn{3}{|l|}{ Emissions Savings (physical) } \\
\hline \multicolumn{3}{|l|}{ Primary } \\
\hline $\mathrm{CO}_{2}$ & $\mathrm{mmt}$ & 1,263 \\
\hline $\mathrm{NO}_{\mathrm{x}}$ & $\mathrm{kt}$ & 744 \\
\hline $\mathrm{Hg}$ & ton & 2.8 \\
\hline $\mathrm{N}_{2} \mathrm{O}$ & $\mathrm{kt}$ & 11.8 \\
\hline $\mathrm{N}_{2} \mathrm{O}$ & $\mathrm{mmt} \mathrm{CO}_{2} \mathrm{eq}$ & 3.5 \\
\hline $\mathrm{CH}_{4}$ & $\mathrm{kt}$ & 84 \\
\hline $\mathrm{CH}_{4}$ & $\mathrm{mmt} \mathrm{CO}_{2} \mathrm{eq}$ & 2.1 \\
\hline $\mathrm{SO}_{2}$ & $\mathrm{kt}$ & 1,123 \\
\hline \multicolumn{3}{|l|}{ Upstream } \\
\hline $\mathrm{CO}_{2}$ & $\mathrm{mmt}$ & 76 \\
\hline $\mathrm{NO}_{\mathrm{x}}$ & $\mathrm{kt}$ & 1,077 \\
\hline $\mathrm{Hg}$ & ton & 0.0 \\
\hline $\mathrm{N}_{2} \mathrm{O}$ & $\mathrm{kt}$ & 0.5 \\
\hline $\mathrm{N}_{2} \mathrm{O}$ & $\mathrm{mmt} \mathrm{CO}_{2} \mathrm{eq}$ & 0.1 \\
\hline $\mathrm{CH}_{4}$ & $\mathrm{kt}$ & 6,413 \\
\hline $\mathrm{CH}_{4}$ & $\mathrm{mmt} \mathrm{CO}_{2} \mathrm{eq}$ & 160 \\
\hline $\mathrm{SO}_{2}$ & $\mathrm{kt}$ & 10 \\
\hline \multicolumn{3}{|l|}{ Full-Fuel-Cycle (total) } \\
\hline $\mathrm{CO}_{2}$ & $\mathrm{mmt}$ & 1,339 \\
\hline $\mathrm{NO}_{\mathrm{x}}$ & $\mathrm{kt}$ & 1,821 \\
\hline $\mathrm{Hg}$ & ton & 2.8 \\
\hline $\mathrm{N}_{2} \mathrm{O}$ & $\mathrm{kt}$ & 12.3 \\
\hline $\mathrm{N}_{2} \mathrm{O}$ & $\mathrm{mmt} \mathrm{CO}_{2} \mathrm{eq}$ & 3.7 \\
\hline $\mathrm{CH}_{4}$ & $\mathrm{kt}$ & 6,497 \\
\hline $\mathrm{CH}_{4}$ & $\mathrm{mmt} \mathrm{CO}_{2} \mathrm{eq}$ & 162 \\
\hline $\mathrm{SO}_{2}$ & $\mathrm{kt}$ & 1,133 \\
\hline
\end{tabular}


Table 4.16. (contd)

\begin{tabular}{|c|c|c|}
\hline \multicolumn{3}{|l|}{ Emissions Savings (monetized) } \\
\hline \multicolumn{3}{|l|}{ Primary } \\
\hline \multicolumn{3}{|l|}{$\mathrm{CO}_{2}$ (global) } \\
\hline $5 \%$ discount rate, average & billion $2012 \$$ & 10.0 \\
\hline $3 \%$ discount rate, average & billion $2012 \$$ & 41.9 \\
\hline $2.5 \%$ discount rate, average & billion $2012 \$$ & 66.2 \\
\hline $3 \%$ discount rate, 95 th $\%$ ile & billion $2012 \$$ & 128.0 \\
\hline \multicolumn{3}{|l|}{$\mathrm{CO}_{2}$ (domestic) } \\
\hline $5 \%$ discount rate, average & billion $2012 \$$ & 0.7 to 2.3 \\
\hline $3 \%$ discount rate, average & billion $2012 \$$ & 2.9 to 9.6 \\
\hline $2.5 \%$ discount rate, average & billion $2012 \$$ & 4.6 to 15.2 \\
\hline $3 \%$ discount rate, 95 th $\%$ ile & billion $2012 \$$ & 9 to 29.4 \\
\hline \multicolumn{3}{|l|}{$\mathrm{NO}_{\mathrm{x}}(7 \%$ discount rate $)$} \\
\hline At $4682012 \$ /$ ton & billion $2012 \$$ & 0.2 \\
\hline At $2,6392012 \$ /$ ton & billion $2012 \$$ & 1.1 \\
\hline At $4,8092012 \$ /$ ton & billion $2012 \$$ & 2.0 \\
\hline \multicolumn{3}{|l|}{ Upstream } \\
\hline \multicolumn{3}{|l|}{$\mathrm{CO}_{2}$ (global) } \\
\hline $5 \%$ discount rate, average & billion $2012 \$$ & 0.6 \\
\hline $3 \%$ discount rate, average & billion $2012 \$$ & 2.5 \\
\hline $2.5 \%$ discount rate, average & billion $2012 \$$ & 4.0 \\
\hline $3 \%$ discount rate, 95 th $\%$ ile & billion $2012 \$$ & 7.7 \\
\hline \multicolumn{3}{|l|}{$\mathrm{CO}_{2}$ (domestic) } \\
\hline $5 \%$ discount rate, average & billion $2012 \$$ & 0 to 0.1 \\
\hline $3 \%$ discount rate, average & billion $2012 \$$ & 0.2 to 0.6 \\
\hline $2.5 \%$ discount rate, average & billion $2012 \$$ & 0.3 to 0.9 \\
\hline $3 \%$ discount rate, 95 th $\%$ ile & billion $2012 \$$ & 0.5 to 1.8 \\
\hline \multicolumn{3}{|l|}{$\mathrm{NO}_{\mathrm{x}}(7 \%$ discount rate $)$} \\
\hline At $4682012 \$ /$ ton & billion $2012 \$$ & 0.2 \\
\hline At $2,6392012 \$ /$ ton & billion $2012 \$$ & 1.2 \\
\hline At $4,8092012 \$ /$ ton & billion $2012 \$$ & 2.1 \\
\hline \multicolumn{3}{|l|}{ Full-Fuel-Cycle (total) } \\
\hline \multicolumn{3}{|l|}{$\mathrm{CO}_{2}$ (global) } \\
\hline $5 \%$ discount rate, average & billion $2012 \$$ & 10.6 \\
\hline $3 \%$ discount rate, average & billion $2012 \$$ & 44.4 \\
\hline $2.5 \%$ discount rate, average & billion $2012 \$$ & 70.2 \\
\hline $3 \%$ discount rate, 95 th $\%$ ile & billion $2012 \$$ & 135.7 \\
\hline \multicolumn{3}{|l|}{$\mathrm{CO}_{2}$ (domestic) } \\
\hline $5 \%$ discount rate, average & billion $2012 \$$ & 0.7 to 2.4 \\
\hline $3 \%$ discount rate, average & billion $2012 \$$ & 3.1 to 10.2 \\
\hline $2.5 \%$ discount rate, average & billion $2012 \$$ & 4.9 to 16.1 \\
\hline $3 \%$ discount rate, 95 th $\%$ ile & billion $2012 \$$ & 9.5 to 31.2 \\
\hline \multicolumn{3}{|l|}{$\mathrm{NO}_{\mathrm{x}}(7 \%$ discount rate $)$} \\
\hline At $4682012 \$ /$ ton & billion $2012 \$$ & 0.4 \\
\hline At $2,6392012 \$ /$ ton & billion $2012 \$$ & 2.3 \\
\hline At $4,8092012 \$ /$ ton & billion $2012 \$$ & 4.1 \\
\hline
\end{tabular}


Table 4.17. Cumulative Consumer Benefits from BECP Residential Energy Code Activities

\begin{tabular}{lll}
\hline NPV & billion 2012\$ & 95 \\
$\begin{array}{c}\text { Consumer Energy Cost Savings } \\
\text { Consumer and Emissions Value }\end{array}$ & & \\
Consumers $+\mathrm{CO}_{2}(1 \mathrm{st})+\mathrm{NO}_{\mathrm{x}}(\mathrm{Low})$ & billion 2012\$ & 106 \\
Consumers $+\mathrm{CO}_{2}(2 \mathrm{nd})+\mathrm{NO}_{\mathrm{x}}(\mathrm{Med})$ & billion 2012\$ & 142 \\
Consumers $+\mathrm{CO}_{2}(3 \mathrm{rd})+\mathrm{NO}_{\mathrm{x}}(\mathrm{Med})$ & billion 2012\$ & 168 \\
Consumers $+\mathrm{CO}_{2}(4 \mathrm{th})+\mathrm{NO}_{\mathrm{x}}(\mathrm{High})$ & billion 2012\$ & 235 \\
\hline
\end{tabular}

Each of the consumer and emissions value estimates above represents a combination of consumer energy cost savings and corresponding scenarios for monetized reduction of $\mathrm{CO}_{2}$ and $\mathrm{NO}_{\mathrm{x}}$. For example, Consumers $+\mathrm{CO}_{2}(1 \mathrm{st})+\mathrm{NO}_{\mathrm{x}}$ (Low) means that savings from the first scenario of $\mathrm{CO}_{2}(5 \%$ discount rate, average, global SCC) were combined with savings from the low $\mathrm{NO}_{\mathrm{x}}$ cost scenario (at $\$ 468$ per ton in $2012 \$$ ) and added to the consumer energy cost savings. 


\subsection{National Energy, Economic, and Environmental Benefits}

This analysis defines DOE BECP impact as improving energy efficiency of the national building model codes and standards, accelerating the adoption of the most recent code (or equivalent), and increasing compliance with the code provisions.

BECP historical and projected energy savings are presented in Table 5.1. For the historical portion of the Program savings, cumulative primary energy savings between 1992 and 2012 total 4quads, with the annual energy savings being approximately 0.5 quads in 2012 . For the projected program savings, accumulated primary energy savings from 2013 through 2040 reach 40.1 quads, with the annual savings of 2.2 quads in 2040. The cumulative energy savings attributed from the Program total nearly 46 quads of FFC energy, or 44 quads of primary energy. The Program may save consumers up to $\$ 230$ billion on their utility bills by 2040 . Table 5.2 provides the breakdown of energy and cost savings between commercial and residential activities.

Table 5.1. Summary of Energy and Cost Savings from BECP Energy Code Activities

\begin{tabular}{|c|c|c|c|c|c|}
\hline & & $\begin{array}{l}\text { Site Energy } \\
\text { Savings, } \\
\text { quads }\end{array}$ & $\begin{array}{l}\text { Primary Energy } \\
\text { Savings, } \\
\text { quads }\end{array}$ & $\begin{array}{l}\text { FFC Energy } \\
\text { Savings, } \\
\text { quads }\end{array}$ & $\begin{array}{l}\text { Energy Cost } \\
\text { Savings } \\
\text { NPV, } \\
\text { billion 2012\$ } \\
\end{array}$ \\
\hline \multicolumn{6}{|c|}{ Historical } \\
\hline & Annual in 2012 & 0.2 & 0.5 & 0.5 & 5.0 \\
\hline & Cumulative 1992-2012 & 2.0 & 4.0 & 4.2 & 44.6 \\
\hline \multicolumn{6}{|c|}{ Projected, 2013-2040 Construction } \\
\hline & Annual in 2040 & 1.2 & 2.2 & 2.3 & 5.2 \\
\hline & Cumulative 2013-2040 & 22.0 & 40.1 & 41.6 & 185.7 \\
\hline \multicolumn{6}{|c|}{ BECP Total } \\
\hline & Annual in 2040 & 1.2 & 2.2 & 2.3 & 5.2 \\
\hline & Cumulative 1992-2040 & 24.0 & 44.1 & 45.7 & 230.3 \\
\hline (a) & \multicolumn{5}{|c|}{$\begin{array}{l}\text { Site energy savings represent direct energy savings to the consumer. Site energy savings multiplied by the energy price } \\
\text { represent energy cost savings to the consumer. }\end{array}$} \\
\hline (b) & \multicolumn{5}{|c|}{$\begin{array}{l}\text { Following the analysis methodology used by DOE's Appliance and Equipment Standards Program, site energy savings were } \\
\text { first converted to the source energy terms, which includes energy used in generation, transmission, and distribution (primary } \\
\text { energy). }\end{array}$} \\
\hline (c) & \multicolumn{5}{|c|}{$\begin{array}{l}\text { Energy used further "upstream" in the mining, processing, and transportation of fuels cycle was calculated using the NIA } \\
\text { PLUS model and added to the primary energy savings to yield full-fuel-cycle (FFC) energy savings. }\end{array}$} \\
\hline
\end{tabular}


Table 5.2. Breakdown of BECP Energy and Cost Savings between Commercial and Residential Activities (quads)

\begin{tabular}{|c|c|c|c|c|c|}
\hline & & $\begin{array}{l}\text { Site Energy } \\
\text { Savings, } \\
\text { quads }\end{array}$ & $\begin{array}{l}\text { Primary Energy } \\
\text { Savings, } \\
\text { quads }\end{array}$ & $\begin{array}{l}\text { FFC Energy } \\
\text { Savings, } \\
\text { quads }\end{array}$ & $\begin{array}{c}\text { Energy Cost } \\
\text { Savings } \\
\text { NPV, } \\
\text { billion 2012\$ } \\
\end{array}$ \\
\hline \multicolumn{6}{|c|}{ Historical } \\
\hline \multicolumn{6}{|c|}{ Annual in 2012} \\
\hline & Commercial & 0.2 & 0.3 & 0.3 & 3.3 \\
\hline & Residential & 0.1 & 0.1 & 0.2 & 1.7 \\
\hline \multicolumn{6}{|c|}{ Cumulative 1992-2012 } \\
\hline & Commercial & 1.2 & 2.8 & 2.8 & 29.0 \\
\hline & Residential & 0.7 & 1.3 & 1.4 & 15.6 \\
\hline \multicolumn{6}{|c|}{ Projected } \\
\hline \multicolumn{6}{|c|}{ Annual in 2040} \\
\hline & Commercial & 0.7 & 1.3 & 1.3 & 2.9 \\
\hline & Residential & 0.5 & 0.9 & 0.9 & 2.3 \\
\hline \multicolumn{6}{|c|}{ Cumulative 2013-2040 } \\
\hline & Commercial & 12.6 & 24.2 & 25.0 & 106.1 \\
\hline & Residential & 9.4 & 15.9 & 16.6 & 79.6 \\
\hline \multicolumn{6}{|c|}{ BECP Total } \\
\hline \multicolumn{6}{|c|}{ Annual in 2040} \\
\hline & Commercial & 0.7 & 1.3 & 1.3 & 2.9 \\
\hline & Residential & 0.5 & 0.9 & 0.9 & 2.3 \\
\hline \multicolumn{6}{|c|}{ Cumulative 1992-2040 } \\
\hline & Commercial & 13.8 & 27.0 & 27.8 & 135.1 \\
\hline & Residential & 10.2 & 17.2 & 17.9 & 95.2 \\
\hline () & \multicolumn{5}{|c|}{$\begin{array}{l}\text { Site energy savings represent direct energy savings to the consumer. Site energy savings multiplied by the energy price } \\
\text { represent energy cost savings to the consumer. }\end{array}$} \\
\hline (b) & \multicolumn{5}{|c|}{$\begin{array}{l}\text { Following the analysis methodology used by DOE's Appliance and Equipment Standards Program, site energy savings were } \\
\text { first converted to the source energy terms, which includes energy used in generation, transmission, and distribution (primary } \\
\text { energy). }\end{array}$} \\
\hline (c) & \multicolumn{5}{|c|}{$\begin{array}{l}\text { Energy used further "upstream" in the mining, processing, and transportation of fuels cycle was calculated using the NIA } \\
\text { PLUS model and added to the primary energy savings to yield full-fuel-cycle (FFC) energy savings. }\end{array}$} \\
\hline
\end{tabular}

Detailed annual primary energy savings and FFC energy savings are presented in Table 5.3 and Table 5.4, respectively. 
Table 5.3. BECP Historical and Projected Primary Energy Savings (quads)

\begin{tabular}{|c|c|c|c|c|}
\hline & $\begin{array}{c}\text { Annual } \\
\text { Primary } \\
\text { quads } \\
\end{array}$ & $\begin{array}{c}\text { Cumulative Primary } \\
\text { quads }\end{array}$ & & \\
\hline 1992 & 0.00 & 0.00 & & \\
\hline 1993 & 0.01 & 0.01 & & \\
\hline 1994 & 0.01 & 0.02 & & \\
\hline 1995 & 0.01 & 0.03 & & \\
\hline 1996 & 0.02 & 0.05 & & \\
\hline 1997 & 0.04 & 0.09 & & \\
\hline 1998 & 0.05 & 0.14 & & \\
\hline 1999 & 0.06 & 0.20 & & \\
\hline 2000 & 0.08 & 0.28 & & \\
\hline 2001 & 0.11 & 0.39 & & \\
\hline 2002 & 0.15 & 0.54 & & \\
\hline 2003 & 0.19 & 0.73 & & \\
\hline 2004 & 0.23 & 0.96 & & \\
\hline 2005 & 0.27 & 1.23 & & \\
\hline 2006 & 0.31 & 1.54 & & \\
\hline 2007 & 0.35 & 1.88 & & \\
\hline 2008 & 0.38 & 2.26 & & \\
\hline 2009 & 0.41 & 2.67 & & \\
\hline 2010 & 0.43 & 3.11 & & \\
\hline 2011 & 0.45 & 3.56 & Annual & Cumulative \\
\hline 2012 & 0.48 & 4.04 & \multicolumn{2}{|c|}{ Post 2012 construction only } \\
\hline 2013 & 0.53 & 4.58 & 0.05 & 0.05 \\
\hline 2014 & 0.57 & 5.15 & 0.09 & 0.13 \\
\hline 2015 & 0.62 & 5.76 & 0.13 & 0.27 \\
\hline 2016 & 0.71 & 6.47 & 0.23 & 0.49 \\
\hline 2017 & 0.79 & 7.27 & 0.31 & 0.80 \\
\hline 2018 & 0.87 & 8.14 & 0.39 & 1.19 \\
\hline 2019 & 0.99 & 9.13 & 0.50 & 1.69 \\
\hline 2020 & 1.10 & 10.22 & 0.61 & 2.30 \\
\hline 2021 & 1.13 & 11.35 & 0.64 & 2.94 \\
\hline 2022 & 1.22 & 12.57 & 0.73 & 3.68 \\
\hline 2023 & 1.31 & 13.87 & 0.82 & 4.50 \\
\hline 2024 & 1.39 & 15.27 & 0.91 & 5.41 \\
\hline 2025 & 1.47 & 16.74 & 0.99 & 6.39 \\
\hline 2026 & 1.44 & 18.18 & 0.96 & 7.35 \\
\hline 2027 & 1.51 & 19.69 & 1.02 & 8.38 \\
\hline 2028 & 1.57 & 21.26 & 1.09 & 9.46 \\
\hline 2029 & 1.64 & 22.90 & 1.15 & 10.61 \\
\hline 2030 & 1.70 & 24.59 & 1.21 & 11.83 \\
\hline 2031 & 1.71 & 26.30 & 1.23 & 13.05 \\
\hline 2032 & 1.77 & 28.07 & 1.28 & 14.34 \\
\hline 2033 & 1.83 & 29.90 & 1.34 & 15.68 \\
\hline 2034 & 1.88 & 31.78 & 1.40 & 17.08 \\
\hline 2035 & 1.93 & 33.72 & 1.45 & 18.53 \\
\hline 2036 & 1.99 & 35.70 & 1.50 & 20.03 \\
\hline 2037 & 2.04 & 37.74 & 1.55 & 21.58 \\
\hline 2038 & 2.08 & 39.82 & 1.60 & 23.18 \\
\hline 2039 & 2.13 & 41.95 & 1.65 & 24.83 \\
\hline 2040 & 2.18 & 44.13 & 1.69 & 26.52 \\
\hline
\end{tabular}


Table 5.4. BECP Historical and Projected Full-Fuel-Cycle Energy Savings (quads)

\begin{tabular}{|c|c|c|c|c|}
\hline & $\begin{array}{c}\text { Annual FFC } \\
\text { quads }\end{array}$ & $\begin{array}{c}\text { Cumulative FFC } \\
\text { quads }\end{array}$ & & \\
\hline 1992 & 0.0 & 0.0 & & \\
\hline 1993 & 0.0 & 0.0 & & \\
\hline 1994 & 0.0 & 0.0 & & \\
\hline 1995 & 0.0 & 0.0 & & \\
\hline 1996 & 0.0 & 0.1 & & \\
\hline 1997 & 0.0 & 0.1 & & \\
\hline 1998 & 0.1 & 0.1 & & \\
\hline 1999 & 0.1 & 0.2 & & \\
\hline 2000 & 0.1 & 0.3 & & \\
\hline 2001 & 0.1 & 0.4 & & \\
\hline 2002 & 0.2 & 0.6 & & \\
\hline 2003 & 0.2 & 0.8 & & \\
\hline 2004 & 0.2 & 1.0 & & \\
\hline 2005 & 0.3 & 1.3 & & \\
\hline 2006 & 0.3 & 1.6 & & \\
\hline 2007 & 0.4 & 1.9 & & \\
\hline 2008 & 0.4 & 2.3 & & \\
\hline 2009 & 0.4 & 2.8 & & \\
\hline 2010 & 0.4 & 3.2 & & \\
\hline 2011 & 0.5 & 3.7 & \multirow{2}{*}{\multicolumn{2}{|c|}{$\begin{array}{cc}\text { Total, Annual } & \text { Total, Cumulativ } \\
\text { Post } 2012 \text { construction only }\end{array}$}} \\
\hline 2012 & 0.5 & 4.2 & & \\
\hline 2013 & 0.5 & 4.7 & 0.0 & 0.0 \\
\hline 2014 & 0.6 & 5.3 & 0.1 & 0.1 \\
\hline 2015 & 0.6 & 6.0 & 0.1 & 0.3 \\
\hline 2016 & 0.7 & 6.7 & 0.2 & 0.5 \\
\hline 2017 & 0.8 & 7.5 & 0.3 & 0.8 \\
\hline 2018 & 0.9 & 8.4 & 0.4 & 1.2 \\
\hline 2019 & 1.0 & 9.4 & 0.5 & 1.7 \\
\hline 2020 & 1.1 & 10.6 & 0.6 & 2.4 \\
\hline 2021 & 1.2 & 11.7 & 0.7 & 3.0 \\
\hline 2022 & 1.3 & 13.0 & 0.8 & 3.8 \\
\hline 2023 & 1.4 & 14.3 & 0.9 & 4.7 \\
\hline 2024 & 1.4 & 15.8 & 0.9 & 5.6 \\
\hline 2025 & 1.5 & 17.3 & 1.0 & 6.6 \\
\hline 2026 & 1.5 & 18.8 & 1.0 & 7.6 \\
\hline 2027 & 1.6 & 20.4 & 1.1 & 8.7 \\
\hline 2028 & 1.6 & 22.0 & 1.1 & 9.8 \\
\hline 2029 & 1.7 & 23.7 & 1.2 & 11.0 \\
\hline 2030 & 1.8 & 25.5 & 1.3 & 12.3 \\
\hline 2031 & 1.8 & 27.2 & 1.3 & 13.5 \\
\hline 2032 & 1.8 & 29.1 & 1.3 & 14.9 \\
\hline 2033 & 1.9 & 31.0 & 1.4 & 16.3 \\
\hline 2034 & 2.0 & 32.9 & 1.5 & 17.7 \\
\hline 2035 & 2.0 & 34.9 & 1.5 & 19.2 \\
\hline 2036 & 2.1 & 37.0 & 1.6 & 20.8 \\
\hline 2037 & 2.1 & 39.1 & 1.6 & 22.4 \\
\hline 2038 & 2.2 & 41.3 & 1.7 & 24.1 \\
\hline 2039 & 2.2 & 43.5 & 1.7 & 25.8 \\
\hline 2040 & 2.3 & 45.7 & 1.8 & 27.5 \\
\hline
\end{tabular}

A summary of emissions savings from BECP energy code activities calculated based on the FFC analysis is presented in Table 5.5. 
Table 5.5. Summary of Emissions Savings from BECP Energy Code Activities

\begin{tabular}{|c|c|c|c|c|c|c|c|c|}
\hline & $\begin{array}{c}\mathrm{CO}_{2} \\
(\mathrm{mmt})\end{array}$ & $\begin{array}{c}\text { NO }_{x} \\
(k t) \\
\end{array}$ & $\begin{array}{c}\mathrm{Hg} \\
\text { (ton) }\end{array}$ & $\begin{array}{l}\mathrm{N}_{2} \mathrm{O} \\
(\mathrm{kt}) \\
\end{array}$ & $\begin{array}{c}\mathrm{N}_{2} \mathrm{O} \\
(\mathrm{mmt} \\
\left.\mathrm{CO} \mathrm{O}_{2} \mathrm{eq}\right)\end{array}$ & $\begin{array}{c}\mathrm{CH}_{4} \\
(\mathrm{kt}) \\
\end{array}$ & $\begin{array}{c}\mathrm{CH}_{4} \\
(\mathrm{mmt} \\
\left.\mathrm{CO}_{2} \mathrm{eq}\right)\end{array}$ & $\begin{array}{l}\mathrm{SO}_{2} \\
(\mathrm{kt})\end{array}$ \\
\hline \multicolumn{9}{|l|}{ Historical } \\
\hline Annual in 2012 & 36 & 80 & 0.1 & 0.4 & 0.1 & 159 & 4 & 46 \\
\hline Cumulative 1992-2012 & 300 & 664 & 0.6 & 3.3 & 1.0 & 1,347 & 34 & 386 \\
\hline \multicolumn{9}{|c|}{ Projected, 2013-2040 Construction } \\
\hline Annual in 2040 & 185 & 194 & 0.4 & 1.8 & 0.5 & 796 & 20 & 116 \\
\hline Cumulative 2013-2040 & 3,178 & 3,855 & 6.9 & 32.1 & 9.6 & 14,095 & 352 & 3,489 \\
\hline \multicolumn{9}{|l|}{ BECP Total } \\
\hline Annual in 2040 & 185 & 194 & 0.4 & 1.8 & 0.5 & 796 & 20 & 116 \\
\hline Cumulative 1992-2040 & 3,478 & 4,519 & 7.6 & 35.4 & 10.5 & 15,441 & 386 & 3,875 \\
\hline
\end{tabular}

Cumulative emissions reductions between 1992 and 2040 include almost 3.5 billion metric tons (Mt) of $\mathrm{CO}_{2}, 4.5$ million tons of $\mathrm{NO}_{x}, 7.6$ tons of $\mathrm{Hg}$, and 3.9 million tons of $\mathrm{SO}_{2}$.

The value of the $\mathrm{CO}_{2}$ emission reductions is $\$ 2.0$ to $\$ 6.4$ billion (2012\$) based on 2013 domestic social carbon values and a 5\% discount rate, or \$28 billion based on 2013 global SCC, while $\mathrm{NO}_{\mathrm{x}}$ savings contribute at least another $\$ 1.1$ billion of savings (at $\$ 468$ per ton in 2012\$). Energy cost savings presented in Table 5.1, combined with physical and monetized emission savings presented in Table 5.5, capture consumer benefits to the nation from the BECP energy code activities.

Combined consumer benefits from BECP activities are shown in Table 5.6 and Table 5.7. Depending on the price of $\mathrm{CO}_{2}$ and $\mathrm{NO}_{\mathrm{x}}$, the NPV of overall consumer benefits can range between $\$ 259$ and almost $\$ 594$ billion (2012\$). Out of that total, the energy cost savings constitute $\$ 230$ billion (2012\$).

Table 5.6. National Benefits from BECP Energy Code Activities, 1992-2040

\begin{tabular}{|c|c|c|c|c|}
\hline Cumulative Results & Units & $\begin{array}{c}\text { Commercial (1992- } \\
\text { 2040) }\end{array}$ & $\begin{array}{c}\text { Residential (1992- } \\
\text { 2040) }\end{array}$ & $\begin{array}{l}\text { Total BECP } \\
(1992-2040)\end{array}$ \\
\hline \multicolumn{5}{|l|}{ Energy Savings } \\
\hline Site & quads & 13.8 & 10.2 & 24.0 \\
\hline Primary & quads & 27.0 & 17.2 & 44.1 \\
\hline Full-Fuel-Cycle (total) & quads & 27.8 & 17.9 & 45.7 \\
\hline \multicolumn{5}{|l|}{ Economic Impacts } \\
\hline Energy Cost Savings & billion $2012 \$$ & 135 & 95 & 230 \\
\hline \multicolumn{5}{|c|}{ Emissions Savings (physical) } \\
\hline \multicolumn{5}{|l|}{ Full-Fuel-Cycle (total) } \\
\hline $\mathrm{CO}_{2}$ & $\mathrm{mmt}$ & 2,138 & 1,339 & 3,478 \\
\hline $\mathrm{NO}_{\mathrm{x}}$ & $\mathrm{kt}$ & 2,699 & 1,821 & 4,519 \\
\hline $\mathrm{Hg}$ & ton & 4.8 & 2.8 & 8 \\
\hline $\mathrm{N}_{2} \mathrm{O}$ & $\mathrm{kt}$ & 23.1 & 12.3 & 35 \\
\hline $\mathrm{N}_{2} \mathrm{O}$ & $\mathrm{mmt} \mathrm{CO}_{2} \mathrm{eq}$ & 6.9 & 3.7 & 11 \\
\hline $\mathrm{CH}_{4}$ & $\mathrm{kt}$ & 8,945 & 6,497 & 15,441 \\
\hline $\mathrm{CH}_{4}$ & $\mathrm{mmt} \mathrm{CO} \mathrm{CO}_{2}$ & 224 & 162 & 386 \\
\hline $\mathrm{SO}_{2}$ & $\mathrm{kt}$ & 2,742 & 1,133 & 3,875 \\
\hline
\end{tabular}


Table 5.6. (contd)

\begin{tabular}{|c|c|c|c|c|}
\hline Cumulative Results & Units & $\begin{array}{c}\text { Commercial (1992- } \\
\text { 2040) } \\
\end{array}$ & $\begin{array}{c}\text { Residential (1992- } \\
\text { 2040) }\end{array}$ & $\begin{array}{c}\text { Total } \\
\text { BECP } \\
(1992-2040) \\
\end{array}$ \\
\hline \multicolumn{5}{|l|}{$\begin{array}{l}\text { Emissions Savings (monetized) } \\
\text { Full-Fuel-Cycle (total) }\end{array}$} \\
\hline \multicolumn{5}{|l|}{$\mathrm{CO}_{2}$ (global) } \\
\hline $5 \%$ discount rate, average & billion $2012 \$$ & 17.3 & 10.6 & 28.0 \\
\hline $3 \%$ discount rate, average & billion $2012 \$$ & 71.3 & 44.4 & 115.7 \\
\hline $2.5 \%$ discount rate, average & billion $2012 \$$ & 112.6 & 70.2 & 182.8 \\
\hline $3 \%$ discount rate, 95 th $\%$ ile & billion $2012 \$$ & 216.8 & 135.7 & 352.6 \\
\hline \multicolumn{5}{|l|}{$\mathrm{CO}_{2}$ (domestic) } \\
\hline $5 \%$ discount rate, average & billion $2012 \$$ & 1.2 to 4 & 0.7 to 2.4 & 2 to 6.4 \\
\hline $3 \%$ discount rate, average & billion $2012 \$$ & 5 to 16.4 & 3.1 to 10.2 & 8.1 to 26.6 \\
\hline $2.5 \%$ discount rate, average & billion $2012 \$$ & 7.9 to 25.9 & 4.9 to 16.1 & 12.8 to 42 \\
\hline $3 \%$ discount rate, 95 th $\%$ ile & billion $2012 \$$ & 15.2 to 49.9 & 9.5 to 31.2 & 24.7 to 81.1 \\
\hline \multicolumn{5}{|l|}{$\mathrm{NO}_{\mathrm{x}}(7 \%$ discount rate $)$} \\
\hline At $4682012 \$ /$ ton & billion $2012 \$$ & 0.7 & 0.4 & 1.1 \\
\hline At $2,6392012 \$ /$ ton & billion $2012 \$$ & 3.8 & 2.3 & 6.0 \\
\hline At $4,8092012 \$ /$ ton & billion $2012 \$$ & 6.9 & 4.1 & 11.0 \\
\hline
\end{tabular}

Each one of the consumer and emissions value estimates shown in Table 5.7 represent a combination of consumer energy cost savings, and corresponding scenarios for monetized reduction of $\mathrm{CO}_{2}$ and $\mathrm{NOx}$. For example, Consumers $+\mathrm{CO}_{2}(1 \mathrm{st})+\mathrm{NO}_{\mathrm{x}}$ (Low) means that savings from the first scenario of $\mathrm{CO}_{2}(5 \%$ discount rate, average, global SCC) were combined with savings from the low $\mathrm{NO}_{\mathrm{x}}$ cost scenario (at $\$ 468$ per ton in 2012\$) and added to the consumer energy cost savings.

Table 5.7. Consumer Cumulative Benefits of the BECP Activities, 1992-2040

\begin{tabular}{llccc}
\hline \multicolumn{1}{c}{ Cumulative Results } & & $\begin{array}{c}\text { Commercial } \\
(\mathbf{1 9 9 2 - 2 0 4 0 )}\end{array}$ & $\begin{array}{c}\text { Residential } \\
(\mathbf{1 9 9 2 - 2 0 4 0 )}\end{array}$ & $\begin{array}{c}\text { Total BECP } \\
(\mathbf{1 9 9 2 - 2 0 4 0 )}\end{array}$ \\
\hline $\begin{array}{l}\text { NPV } \\
\quad \text { Consumer Energy Cost Savings }\end{array}$ & billion 2012\$ & 135 & 95 & 230 \\
Consumer and Emissions Value & & & & \\
Consumers $+\mathrm{CO}_{2}(1 \mathrm{st})+\mathrm{NO}_{\mathrm{x}}(\mathrm{Low})$ & billion 2012\$ & 153 & 106 & 259 \\
Consumers $+\mathrm{CO}_{2}(2 \mathrm{nd})+\mathrm{NO}_{\mathrm{x}}(\mathrm{Med})$ & billion 2012\$ & 210 & 142 & 352 \\
Consumers $+\mathrm{CO}_{2}(3 \mathrm{rd})+\mathrm{NO}_{\mathrm{x}}(\mathrm{Med})$ & billion 2012\$ & 251 & 168 & 419 \\
Consumers $+\mathrm{CO}_{2}(4 \mathrm{th})+\mathrm{NO}_{\mathrm{x}}(\mathrm{High})$ & billion 2012\$ & 359 & 235 & 594 \\
\hline
\end{tabular}

The estimated cumulative benefits from the Program through 2040 are significant. The cumulative energy savings attributed from the Program total nearly 46 quads of FFC energy, or 44 quads of primary energy, equivalent to almost an entire year's worth of primary energy consumption from the U.S. residential and commercial sectors at current consumption rates. The Program may save consumers up to $\$ 230$ billion on their utility bills by 2040. Annual carbon savings reach 36 million tons at the end of 2012 and the cumulative savings by 2040 are estimated at 3,478 million tons. 
Finally, BECP's cumulative FFC savings of emissions of $\mathrm{CO}_{2}, \mathrm{~N}_{2} \mathrm{O}$, and $\mathrm{CH}_{4}$ in $\mathrm{CO}_{2}$-equivalents in Table ES.2 are almost 3.9 billion metric tons. That is equivalent to three-quarters of all energy-related emissions of the United States in 2012. These benefits do not count the reduction of other energy-related air pollutants shown in Table ES.2, or billions of dollars in saved future investment in facilities to supply the natural gas, electricity, and fuel oil to the residential and commercial sectors that would not be needed. BECP efforts clearly make a difference to the economy and citizens of the United States. 


\subsection{References}

10 CFR 429 and 430. 2013. "Energy Conservation Program: Energy Conservation Standards for Standby Mode and Off Mode for Microwave Ovens; Final Rule." Code of Federal Regulations, U.S. Department of Energy.

American Society of Heating, Refrigerating, and Air-Conditioning Engineers (ASHRAE) and Illuminating Engineering Society of North America (IESNA). 1990. Energy Efficient Design of New Buildings Except Low-Rise Residential Buildings, ANSI/ASHRAE/IES 90.1-1989, Atlanta, Georgia.

American Society of Heating, Refrigerating, and Air-Conditioning Engineers (ASHRAE) and Illuminating Engineering Society of North America (IESNA). 2004. Energy Standard for Buildings Except Low-Rise Residential Buildings. ANSI/ASHRAE/IESNA Standard 90.1-2004, Atlanta, Georgia.

American Society of Heating, Refrigerating, and Air-Conditioning Engineers (ASHRAE) and Illuminating Engineering Society of North America (IESNA). 2007. Energy Standard for Buildings Except Low-Rise Residential Buildings. ANSI/ASHRAE/IESNA Standard 90.1-2007, Atlanta, Georgia.

American Society of Heating, Refrigerating, and Air-Conditioning Engineers (ASHRAE) and Illuminating Engineering Society (IES). 2010. Energy Standard for Buildings Except Low-Rise Residential Buildings. ANSI/ASHRAE/IES Standard 90.1-2010, Atlanta, Georgia.

Energy Information Administration (EIA). 2006. Commercial Building Energy Consumption Survey 2003. Detailed tables, available as .pdf file alltables[1].pdf, accessed at: http://www.eia.gov/emeu/cbecs/cbecs2003/detailed tables_2003/detailed tables_2003.html.

Energy Information Administration (EIA). 2013. U.S. Energy Information Administration, Assumptions to the Annual Energy Outlook 2013: Residential Demand Module. Accessed at: http://www.eia.gov/forecasts/aeo/assumptions/pdf/residential.pdf.

Energy Policy Act of 1992 (EPAct 1992). Public Law 102-486, Title I-Energy Efficiency, Subtitle ABuildings, Sec. 101. Building energy efficiency standards, October 24, 1992.

Halverson M, E Richman, B Liu, and D Winiarski. 2011a. ANSI/ASHRAE/IESNA Standard 90.1-2007 Preliminary Determination Quantitative Analysis. PNNL-20456, Pacific Northwest National Laboratory, Richland, Washington. Available at:

http://www.energycodes.gov/sites/default/files/documents/BECP FinalQuantiativeAnalysisReport9012007Determination_May2011_v00.pdf.

Halverson MA, MI Rosenberg, JL Williamson, EE Richman, and B Liu. 2011b. ANSI/ASHRAE/IES Standard 90.1-2010 Final Qualitative Determination. PNNL-20883, Pacific Northwest National Laboratory, Richland, Washington.

International Code Council (ICC). 2000. International Energy Conservation Code 2000. Country Club Hills, Illinois. 
International Code Council (ICC). 2003. International Energy Conservation Code 2003. Country Club Hills, Illinois.

International Code Council (ICC). 2006. International Energy Conservation Code 2006. Country Club Hills, Illinois.

International Code Council (ICC). 2009. International Energy Conservation Code 2009. Country Club Hills, Illinois.

International Conference of Building Officials; Southern Building Code Congress International, Inc.; Building Officials \& Code Administrators International, Inc. 1977. Model Code for Energy Conservation (MCEC) in New Building Construction. Washington, D.C.

Jarnagin, RE, and GK Bandyopadhyay. 2010. Weighting Factors for the Commercial Building Prototypes Used in the Development of ANSI/ASHRAE/IESNA Standard 90.1-2010. PNNL-19116, Pacific Northwest National Laboratory, Richland, Washington.

Misuriello H, S Kwatra, M Kushler, and S Nowak. 2012. Building Energy Code Advancement through Utility Support and Engagement. Report Number A126, American Council for an Energy Efficient Economy, Washington, D.C.

Taylor T, N Fernandez, and R Lucas. 2012. Methodology for Evaluating Cost-Effectiveness of Residential Energy Codes Changes. PNNL-21294. Prepared for the U.S. Department of Energy, Office of Energy Efficiency and Renewable Energy. Pacific Northwest National Laboratory, Richland, Washington. Accessed June 2013 at: http://www.energycodes.gov/sites/default/files/documents/ residential_methodology.pdf.

Thornton BA, W Wang, H Cho, B Liu, MI Rosenberg, Y Xie, VV Mendon, EE Richman, J Zhang, and RA Athalye. 2011. Achieving the 30\% Goal: Energy and Cost Savings Analysis of ASHRAE Standard 90.1-2010. PNNL-20405, Pacific Northwest National Laboratory, Richland, Washington. Accessed June 2013 at: http://www.energycodes.gov/development/commercial/90.1_models.

U.S. Department of Energy (DOE). 2010. A Retrospective Analysis of Commercial Building Energy Codes: 1990-2008. Appendix A, available as .pdf file, accessed at: http://www.pnnl.gov/main/publications/external/technical reports/PNNL-19887.pdf. 


\subsection{Bibliography}

67 FR 46464 No. 250. July 15, 2002. "Building Energy Standards Program: Determination Regarding Energy Efficiency Improvements in the Energy Standard for Buildings, Except Low-Rise Residential Buildings, ASHRAE/IESNA Standard 90.1-1999.” Federal Register. U.S. Department of Energy, Washington, D.C.

73 FR 79868 No. 250. December 30, 2008. "Building Energy Standards Program: Determination Regarding Energy Efficiency Improvements in the Energy Standard for Buildings, Except Low- Rise Residential Buildings, ANSI/ASHRAE/IESNA Standard 90.1-2004.” Federal Register.

U.S. Department of Energy, Washington, D.C.

75 FR 54117 No. 171. September 3, 2010. "Building Energy Standards Program: Preliminary Determination Regarding Energy Efficiency Improvements in the Energy Standard for Buildings, Except Low-Rise Residential Buildings, ANSI/ASHRAE/IESNA Standard 90.1-2007." Federal Register. U.S. Department of Energy, Washington, D.C.

75 FR 54131 No. 171. September 3, 2010. "Updating State Residential Building Energy Efficiency Codes.” Federal Register. U.S. Department of Energy, Washington, D.C.

76 FR 42688 No. 138. July 19, 2011. "Updating State Residential Building Energy Efficiency Codes." Federal Register. U.S. Department of Energy, Washington, D.C.

American Recovery and Reinvestment Act (ARRA). 2009. Public Law 111-5. $111^{\text {th }}$ Congress. February 17, 2009. U.S. Government Printing Office, Washington, D.C.

American Society of Heating, Refrigerating and Air-Conditioning Engineers (ASHRAE) and Illuminating Engineering Society of North America (IESNA). 1975. Energy Conservation in New Building Design. ASHRAE Standard 90-75, Atlanta, Georgia.

American Society of Heating, Refrigerating, and Air-Conditioning Engineers (ASHRAE) and Illuminating Engineering Society of North America (IESNA). 1980. Energy Conservation in New Building Design, ANSI/ASHRAE/IES 90A-1980, New York.

American Society of Heating, Refrigerating, and Air-Conditioning Engineers (ASHRAE) and Illuminating Engineering Society of North America (IESNA). 1999. Energy Standard for Buildings Except Low-Rise Residential Buildings. ANSI/ASHRAE/IESNA Standard 90.1-1999, Atlanta, Georgia.

Barbose GL, CA Goldman, IM Hoffman, and M Billingsley. 2013. The Future of Utility CustomerFunded Energy Efficiency Programs in the United States: Projected Spending and Savings to 2025. LBNL-5803E, Lawrence Berkeley National Laboratory, Berkeley, California.

Bartlett R, MA Halverson, and K Gowri. 2009. Impacts of Standard 90.1-2007 for Commercial Buildings at State Level. September 2009. PNNL-18544, Pacific Northwest National Laboratory, Richland, Washington. 
Baylon D and M Kennedy. 2008. Baseline Characteristics of the 2002-2004 Non-Residential Sector in Idaho, Montana, Oregon and Washington. Prepared for the Northwest Energy Efficiency Alliance by Ecotope Consulting Research Design, Seattle, Washington.

Baylon D, M Kennedy, and S Borrelli. 2001. Baseline Characteristics of the Non-Residential Sector in Idaho, Montana, Oregon and Washington. Prepared for the Northwest Energy Efficiency Alliance by Ecotope Consulting Research Design, Seattle, Washington.

Baylon D, P Storm, K Geraghty, and B Davis. 2012. 2011 Residential Building Stock Assessment: Single-Family Characteristics and Energy Use. Ecotope, Inc. for Northwest Energy Efficiency Alliance, Seattle, Washington.

Belzer DB, KA Cort, DW Winiarski, EE Richman, and M Friedrich. 2002. Analysis of Potential Benefits and Cost of Adopting ASHRAE Standard 90.1-1999 as a Commercial Building Energy Code in Illinois Jurisdictions. PNNL-13870, Pacific Northwest National Laboratory, Richland, Washington.

Britt/Makela Group, Inc., and International Code Council. 2005. Indiana Commercial Energy Code Baseline Study. Prepared for the Indiana Department of Commerce, Energy and Recycling Division, Indianapolis, Indiana.

Council of American Building Officials. 1992. Model Energy Code 1992. Falls Church, Virginia.

Council of American Building Officials. 1995. Model Energy Code 1995. Falls Church, Virginia.

Devine J. 1997. Non-Compliance with the Washington State Non-Residential Energy Code: Causes and Consequences. Washington State Energy Office, Olympia, Washington.

Eley Associates. 1999. Energy Code Compliance Study: Honolulu and Hawaii Counties. Prepared for the Hawaii Department of Business, Economic Development, and Tourism; Energy, Resources, and Technology Division, San Francisco, California.

Energy Information Administration (EIA). 2007. Residential Energy Consumption Survey 2005. Detailed tables, accessed at: http://www.eia.gov/consumption/residential/data/2005/, file alltables[1].pdf.

Energy Policy and Conservation Act. 1975. (EPAct 1975) Public Law 94-163 (PL-94-163).

December 22, 1975.

GDS Associates (GDS). 2012. New Hampshire Energy Code Compliance Roadmap - Volume 2, Achieving 90\% Compliance with the 2009 International Energy Conservation Code. GDS Associates, Inc., Manchester, New Hampshire.

GDS Associates and ENTECH Engineering. 2000. Survey of Commercial New Construction Activities in New Hampshire. Provided to the New Hampshire Commercial Construction Study Group. Manchester, New Hampshire.

Georgia Environmental Finance Authority (GEFA). 2012. Building Department Pilot Study: Guidance on Effective Enforcement of Georgia's Energy Code. Completed by the Building Codes Assistance Project, the Southeast Energy Efficiency Alliance, and Southface. 
Hadley DL and MA Halverson. 1993. Energy Conservation Potential of the U.S. Department of Energy Interim Commercial Buildings Standards. PNL-7967, Pacific Northwest National Laboratory, Richland, Washington.

Harper B. 2012. The New York Energy Code Compliance Study. Prepared by the Vermont Energy Investment Corporation for The New York State Energy Research and Development Authority, Burlington, Vermont.

International Code Council (ICC). 2012. International Energy Conservation Code 2012. Country Club Hills, Illinois.

Kennedy M. 1997. Energy Consequences of Non-Compliance with the 1994 Washington Nonresidential Energy Code. Washington State University, Richland, Washington.

Lee A, B Standen, S Donohue, M Desu, and Andrew Wood. 2013. Washington Residential Energy Code Compliance. Report \#E12-251, Cadmus Group, Inc. for Northwest Energy Efficiency Alliance, Portland, Oregon.

Lee A, B Standen, S Donohue, M Desu, and A Wood. 2013. Idaho Residential Energy Code

Compliance. Report \#E12-250, Cadmus Group, Inc. for Northwest Energy Efficiency Alliance, Portland, Oregon.

Lucas RG. 2009. Determination for the 2006 International Energy Conservation Code, Residential Buildings - Technical Support Document. PNNL-18806, Pacific Northwest National Laboratory, Richland, Washington.

Makela E and M Britt. 2003a. Final Report - Volume I. In-Field Residential Energy Code Compliance Assessment and Training Project. Britt/Makela Group, LLC.

Makela E and M Britt. 2003b. Final Report Iowa Residential Energy Code Plan Review and Field Inspection Training. Britt/Makela Group, LLC.

Maryland Energy Administration (MEA). 2013. IECC 90\% Compliance Pilot. Residential Review. Newport Partners LLC for Maryland Energy Administration.

Meyers J. 2012. Energy Code Enforcement: Best Practices from the Southwest. Southwest Energy Efficiency Project, Boulder, Colorado.

Midwest Energy Efficiency Alliance (MEEA). 2011. Measuring the Baseline Compliance Rate for Residential and Non-Residential Buildings in Illinois Against the 2009 International Energy Conservation Code". Association of Professional Energy Consultants, Inc. for Midwest Energy Efficiency Alliance, Chicago, Illinois.

Quaid M, S Pletcher, and H Geller. 2013. Energy Efficiency at Fort Collins Utilities: A Role Model for Publicly-Owned Utilities. Southwest Energy Efficiency Project, Boulder, Colorado.

Rekkas A, P Schaffer, D Groshans, and A Lee. 2013. Attributing Building Energy Code Savings to Energy Efficiency Programs. The Cadmus Group, Inc, Portland, Oregon. 
Richman EE, DB Belzer, and DW Winiarski. 2005. Texas State Building Energy Code: Analysis of Potential Benefits and Costs of Commercial Lighting Requirements. PNNL-15356, Pacific Northwest National Laboratory, Richland, Washington.

Schlegel J and B Troncone. 2007. Building Energy Codes in Arizona: Best Practices in Code Support, Compliance, and Enforcement. Prepared for the North American Insulation Manufacturers Association. Southwest Energy Efficiency Project, Boulder, Colorado.

Stellberg S. 2013. Assessment of Energy Efficiency Achievable from Improved Compliance with U.S. Building Energy Codes: 2013 - 2030. Institute for Market Transformation, Washington, D.C.

U.S. Census Bureau (USCB). 2010 (and earlier years). Statistical Abstract of the United States. Government Printing Office, Washington, D.C.

U.S. Department of Energy (DOE). 2010. Annual Energy Review 2009. DOE/EIA-0384. Accessed June 22, 2012 at: http://www.eia.gov/emeu/aer/.

Vermont Department of Public Service (VDPS). 2012. 2011 Vermont Market Characterization and Assessment Study: Business Sector (Commercial and Industrial) New Construction/Major Renovation Buildings. Navigant Consulting Inc. for Vermont Department of Public Service, Burlington, Vermont.

Vermont Public Service Department. 2013. Vermont Residential New Construction Baseline Study Analysis of On-Site Audits. NMR Group, Inc. for Vermont Public Service Department, Somerville, Maryland.

ZING Communications, Inc. 2007. 2007 Commercial Energy Code Compliance Study. Calgary, Alberta, Canada. 


\section{Appendix}

\section{Energy Savings Potential from More Rapid Code Adoption and Compliance, 2013-2040}




\section{Appendix}

\section{Energy Savings Potential from More Rapid Code Adoption and Compliance, 2013-2040}

This appendix contains an estimate of the potential energy savings for residential and commercial code activities assuming immediate adoption and full compliance for 2013-2040. The objective of this analysis was to estimate energy, cost, and emissions that could be saved on post-2013 construction under ideal adoption and compliance conditions. We modeled this situation with an "immediate adoption" scenario, which also included $100 \%$ immediate compliance. The stream of future savings in this scenario corresponded to Stream 2 in the projected savings presented in the results section of the main report (Section 5, Table 5.1).

The methodology for estimating the potential is the same as outlined in Section 2.0 of the report in the sense that we compared two scenarios. Potential savings were calculated as a difference between energy consumption in a base case scenario and energy consumption in the immediate adoption scenario. Separate sets of adoption and compliance assumptions were developed to characterize the base case and immediate adoption scenarios.

The common starting point for adoption for both scenarios was the most recent energy code version adopted in each state (explicitly or implicitly) in 2013. In the base case it was assumed that no further code versions were adopted thereafter.

The immediate adoption scenario assumed that for all code versions starting with IECC 2012/90.12007, the adoption occurred in the year following the publication year of the code (code version +1 year lag). Thus, the IECC 2012 code would be adopted in 2013. This means that the ideal "immediate" adoption path was compared against the adoption status at the beginning of the analysis period. The code adoption assumptions for commercial and residential energy codes are summarized in Table A.1 and Table A.2.

In the immediate adoption scenario, initial compliance was set at $100 \%$ for all states in the year of adoption, including the states with no statewide code and home-rule states. This was consistent with the context of this analysis where the ideal compliance path was compared with the compliance status at the beginning of the analysis period.

In the base case scenario, compliance with the adopted code was assumed to be lower/delayed. In the base case, the same state classifications were used for commercial and residential energy codes as shown in Table 3.7 of Section 3 and Table 4.5 of Section 4. As a result, base case assumptions for initial compliance were set to equal compliance rates for the "without BECP" scenario outlined in Table 3.10 and Table 3.11 of Section 3, and Table 4.8 and Table 4.9 of Section 4.

California, Florida, Oregon, and Washington were included in this analysis because energy savings potential was attribution-free and represented total savings available from code activities between 2013 and 2040 . 
Table A.1. Base Case and Immediate Adoption Scenario, Commercial Energy Codes

\begin{tabular}{|c|c|c|c|c|c|c|c|c|}
\hline & \multirow{2}{*}{$\begin{array}{l}\text { Starting Point } \\
\text { Code in Effect in } 2013\end{array}$} & \multirow[t]{2}{*}{ Base case } & \multicolumn{6}{|c|}{ Immediate Adoption* } \\
\hline & & & $\begin{array}{c}\text { 90.1- } \\
2010^{*}\end{array}$ & $\begin{array}{c}\text { 90.1- } \\
\text { 2013* }\end{array}$ & $\begin{array}{l}\text { 90.1- } \\
\text { 2016* }\end{array}$ & $\begin{array}{c}\text { 90.1- } \\
\text { 2019* }\end{array}$ & $\begin{array}{c}\text { 90.1- } \\
\text { 2022* }\end{array}$ & $\begin{array}{c}\text { 90.1- } \\
2025 *\end{array}$ \\
\hline Alabama & $90.1-2007$ & No Change & 2013 & 2016 & 2019 & 2022 & 2025 & 2028 \\
\hline Alaska & $90.1-1999 / 2001$ & No Change & 2013 & 2016 & 2019 & 2022 & 2025 & 2028 \\
\hline Arizona & $90.1-1999 / 2001$ & No Change & 2013 & 2016 & 2019 & 2022 & 2025 & 2028 \\
\hline Arkansas & $90.1-2007$ & No Change & 2013 & 2016 & 2019 & 2022 & 2025 & 2028 \\
\hline California & $90.1-2007$ & No Change & 2013 & 2016 & 2019 & 2022 & 2025 & 2028 \\
\hline Colorado & $90.1-2004$ & No Change & 2013 & 2016 & 2019 & 2022 & 2025 & 2028 \\
\hline Connecticut & $90.1-2007$ & No Change & 2013 & 2016 & 2019 & 2022 & 2025 & 2028 \\
\hline Delaware & $90.1-2007$ & No Change & 2013 & 2016 & 2019 & 2022 & 2025 & 2028 \\
\hline District of Columbia & $90.1-2007$ & No Change & 2013 & 2016 & 2019 & 2022 & 2025 & 2028 \\
\hline Florida & $90.1-2007$ & No Change & 2013 & 2016 & 2019 & 2022 & 2025 & 2028 \\
\hline Georgia & $90.1-2007$ & No Change & 2013 & 2016 & 2019 & 2022 & 2025 & 2028 \\
\hline Hawaii & $90.1-2004$ & No Change & 2013 & 2016 & 2019 & 2022 & 2025 & 2028 \\
\hline Idaho & $90.1-2007$ & No Change & 2013 & 2016 & 2019 & 2022 & 2025 & 2028 \\
\hline Illinois & $90.1-2010$ & No Change & 2013 & 2016 & 2019 & 2022 & 2025 & 2028 \\
\hline Indiana & $90.1-2007$ & No Change & 2013 & 2016 & 2019 & 2022 & 2025 & 2028 \\
\hline Iowa & $90.1-2007$ & No Change & 2013 & 2016 & 2019 & 2022 & 2025 & 2028 \\
\hline Kansas & $90.1-1999 / 2001$ & No Change & 2013 & 2016 & 2019 & 2022 & 2025 & 2028 \\
\hline Kentucky & $90.1-2007$ & No Change & 2013 & 2016 & 2019 & 2022 & 2025 & 2028 \\
\hline Louisiana & $90.1-2007$ & No Change & 2013 & 2016 & 2019 & 2022 & 2025 & 2028 \\
\hline Maine & $90.1-2007$ & No Change & 2013 & 2016 & 2019 & 2022 & 2025 & 2028 \\
\hline Maryland & $90.1-2010$ & No Change & 2012 & 2016 & 2019 & 2022 & 2025 & 2028 \\
\hline Massachusetts & $90.1-2007$ & No Change & 2013 & 2016 & 2019 & 2022 & 2025 & 2028 \\
\hline Michigan & $90.1-2007$ & No Change & 2013 & 2016 & 2019 & 2022 & 2025 & 2028 \\
\hline Minnesota & $90.1-2004$ & No Change & 2013 & 2016 & 2019 & 2022 & 2025 & 2028 \\
\hline Mississippi & $90.1-1999 / 2001$ & No Change & 2013 & 2016 & 2019 & 2022 & 2025 & 2028 \\
\hline Missouri & $90.1-2010$ & No Change & 2013 & 2016 & 2019 & 2022 & 2025 & 2028 \\
\hline Montana & $90.1-2007$ & No Change & 2013 & 2016 & 2019 & 2022 & 2025 & 2028 \\
\hline Nebraska & $90.1-2007$ & No Change & 2013 & 2016 & 2019 & 2022 & 2025 & 2028 \\
\hline Nevada & $90.1-2007$ & No Change & 2013 & 2016 & 2019 & 2022 & 2025 & 2028 \\
\hline New Hampshire & $90.1-2007$ & No Change & 2013 & 2016 & 2019 & 2022 & 2025 & 2028 \\
\hline New Jersey & $90.1-2007$ & No Change & 2013 & 2016 & 2019 & 2022 & 2025 & 2028 \\
\hline New Mexico & $90.1-2007$ & No Change & 2013 & 2016 & 2019 & 2022 & 2025 & 2028 \\
\hline New York & $90.1-2007$ & No Change & 2013 & 2016 & 2019 & 2022 & 2025 & 2028 \\
\hline North Carolina & $90.1-2007$ & No Change & 2013 & 2016 & 2019 & 2022 & 2025 & 2028 \\
\hline North Dakota & $90.1-2007$ & No Change & 2013 & 2016 & 2019 & 2022 & 2025 & 2028 \\
\hline Ohio & $90.1-2007$ & No Change & 2013 & 2016 & 2019 & 2022 & 2025 & 2028 \\
\hline Oklahoma & $90.1-2004$ & No Change & 2013 & 2016 & 2019 & 2022 & 2025 & 2028 \\
\hline Oregon & $90.1-2007$ & No Change & 2013 & 2016 & 2019 & 2022 & 2025 & 2028 \\
\hline Pennsylvania & $90.1-2007$ & No Change & 2013 & 2016 & 2019 & 2022 & 2025 & 2028 \\
\hline Rhode Island & $90.1-2007$ & No Change & 2013 & 2016 & 2019 & 2022 & 2025 & 2028 \\
\hline South Carolina & $90.1-2007$ & No Change & 2013 & 2016 & 2019 & 2022 & 2025 & 2028 \\
\hline South Dakota & $90.1-1999 / 2001$ & No Change & 2013 & 2016 & 2019 & 2022 & 2025 & 2028 \\
\hline Tennessee & $90.1-2004$ & No Change & 2013 & 2016 & 2019 & 2022 & 2025 & 2028 \\
\hline Texas & $90.1-2007$ & No Change & 2013 & 2016 & 2019 & 2022 & 2025 & 2028 \\
\hline Utah & $90.1-2007$ & No Change & 2013 & 2016 & 2019 & 2022 & 2025 & 2028 \\
\hline Vermont & $90.1-2007$ & No Change & 2013 & 2016 & 2019 & 2022 & 2025 & 2028 \\
\hline Virginia & $90.1-2007$ & No Change & 2013 & 2016 & 2019 & 2022 & 2025 & 2028 \\
\hline Washington & $90.1-2010$ & No Change & 2013 & 2016 & 2019 & 2022 & 2025 & 2028 \\
\hline West Virginia & $90.1-2007$ & No Change & 2013 & 2016 & 2019 & 2022 & 2025 & 2028 \\
\hline Wisconsin & $90.1-2007$ & No Change & 2013 & 2016 & 2019 & 2022 & 2025 & 2028 \\
\hline Wyoming & $90.1-1999 / 2001$ & No Change & 2013 & 2016 & 2019 & 2022 & 2025 & 2028 \\
\hline
\end{tabular}

*Because states typically adopt the IECC and then by reference in the IECC automatically get Standard 90.1, the adoption assumption tables show the adopted versions of the IECC for residential and reference versions of Standard 90.1 for commercial. A one year lag is added to the IECC code version year. Thus Standard 90.1-2010 would be adopted in 2013. 
Table A.2. Base Case and Immediate Adoption Scenario, Residential Energy Codes

\begin{tabular}{|c|c|c|c|c|c|c|c|}
\hline & \multirow{2}{*}{$\begin{array}{l}\text { Starting Point } \\
\text { Code in Effect in } \\
2013\end{array}$} & \multirow[t]{2}{*}{ Base case } & \multicolumn{5}{|c|}{ Immediate Adoption } \\
\hline & & & $\begin{array}{l}\text { IECC } \\
2012\end{array}$ & $\begin{array}{l}\text { IECC } \\
2015\end{array}$ & $\begin{array}{l}\text { IECC } \\
2018\end{array}$ & $\begin{array}{l}\text { IECC } \\
2021\end{array}$ & $\begin{array}{l}\text { IECC } \\
2024\end{array}$ \\
\hline Alabama & IECC 2009 & No Change & 2013 & 2016 & 2019 & 2022 & 2025 \\
\hline Alaska & IECC 2003 & No Change & 2013 & 2016 & 2019 & 2022 & 2025 \\
\hline Arizona & IECC 2003 & No Change & 2013 & 2016 & 2019 & 2022 & 2025 \\
\hline Arkansas & IECC 2003 & No Change & 2013 & 2016 & 2019 & 2022 & 2025 \\
\hline California & IECC 2009 & No Change & 2013 & 2016 & 2019 & 2022 & 2025 \\
\hline Colorado & IECC 2006 & No Change & 2013 & 2016 & 2019 & 2022 & 2025 \\
\hline Connecticut & IECC 2009 & No Change & 2013 & 2016 & 2019 & 2022 & 2025 \\
\hline Delaware & IECC 2009 & No Change & 2013 & 2016 & 2019 & 2022 & 2025 \\
\hline District of Columbia & IECC 2009 & No Change & 2013 & 2016 & 2019 & 2022 & 2025 \\
\hline Florida & IECC 2009 & No Change & 2013 & 2016 & 2019 & 2022 & 2025 \\
\hline Georgia & IECC 2009 & No Change & 2013 & 2016 & 2019 & 2022 & 2025 \\
\hline Hawaii & IECC 2006 & No Change & 2013 & 2016 & 2019 & 2022 & 2025 \\
\hline Idaho & IECC 2009 & No Change & 2013 & 2016 & 2019 & 2022 & 2025 \\
\hline Illinois & IECC 2012 & No Change & 2013 & 2016 & 2019 & 2022 & 2025 \\
\hline Indiana & IECC 2009 & No Change & 2013 & 2016 & 2019 & 2022 & 2025 \\
\hline Iowa & IECC 2009 & No Change & 2013 & 2016 & 2019 & 2022 & 2025 \\
\hline Kansas & IECC 2003 & No Change & 2013 & 2016 & 2019 & 2022 & 2025 \\
\hline Kentucky & IECC 2009 & No Change & 2013 & 2016 & 2019 & 2022 & 2025 \\
\hline Louisiana & IECC 2006 & No Change & 2013 & 2016 & 2019 & 2022 & 2025 \\
\hline Maine & IECC 2009 & No Change & 2013 & 2016 & 2019 & 2022 & 2025 \\
\hline Maryland & IECC 2012 & No Change & 2012 & 2016 & 2019 & 2022 & 2025 \\
\hline Massachusetts & IECC 2009 & No Change & 2013 & 2016 & 2019 & 2022 & 2025 \\
\hline Michigan & IECC 2009 & No Change & 2013 & 2016 & 2019 & 2022 & 2025 \\
\hline Minnesota & IECC 2006 & No Change & 2013 & 2016 & 2019 & 2022 & 2025 \\
\hline Mississippi & IECC 2003 & No Change & 2013 & 2016 & 2019 & 2022 & 2025 \\
\hline Missouri & IECC 2003 & No Change & 2013 & 2016 & 2019 & 2022 & 2025 \\
\hline Montana & IECC 2009 & No Change & 2013 & 2016 & 2019 & 2022 & 2025 \\
\hline Nebraska & IECC 2009 & No Change & 2013 & 2016 & 2019 & 2022 & 2025 \\
\hline Nevada & IECC 2009 & No Change & 2013 & 2016 & 2019 & 2022 & 2025 \\
\hline New Hampshire & IECC 2009 & No Change & 2013 & 2016 & 2019 & 2022 & 2025 \\
\hline New Jersey & IECC 2009 & No Change & 2013 & 2016 & 2019 & 2022 & 2025 \\
\hline New Mexico & IECC 2009 & No Change & 2013 & 2016 & 2019 & 2022 & 2025 \\
\hline New York & IECC 2009 & No Change & 2013 & 2016 & 2019 & 2022 & 2025 \\
\hline North Carolina & IECC 2009 & No Change & 2013 & 2016 & 2019 & 2022 & 2025 \\
\hline North Dakota & IECC 2006 & No Change & 2013 & 2016 & 2019 & 2022 & 2025 \\
\hline Ohio & IECC 2009 & No Change & 2013 & 2016 & 2019 & 2022 & 2025 \\
\hline Oklahoma & IECC 2009 & No Change & 2013 & 2016 & 2019 & 2022 & 2025 \\
\hline Oregon & IECC 2009 & No Change & 2013 & 2016 & 2019 & 2022 & 2025 \\
\hline Pennsylvania & IECC 2009 & No Change & 2013 & 2016 & 2019 & 2022 & 2025 \\
\hline Rhode Island & IECC 2009 & No Change & 2013 & 2016 & 2019 & 2022 & 2025 \\
\hline South Carolina & IECC 2009 & No Change & 2013 & 2016 & 2019 & 2022 & 2025 \\
\hline South Dakota & IECC 2003 & No Change & 2013 & 2016 & 2019 & 2022 & 2025 \\
\hline Tennessee & IECC 2006 & No Change & 2013 & 2016 & 2019 & 2022 & 2025 \\
\hline Texas & IECC 2009 & No Change & 2013 & 2016 & 2019 & 2022 & 2025 \\
\hline Utah & IECC 2006 & No Change & 2013 & 2016 & 2019 & 2022 & 2025 \\
\hline Vermont & IECC 2009 & No Change & 2013 & 2016 & 2019 & 2022 & 2025 \\
\hline Virginia & IECC 2009 & No Change & 2013 & 2016 & 2019 & 2022 & 2025 \\
\hline Washington & IECC 2012 & No Change & 2013 & 2016 & 2019 & 2022 & 2025 \\
\hline West Virginia & IECC 2009 & No Change & 2013 & 2016 & 2019 & 2022 & 2025 \\
\hline Wisconsin & IECC 2006 & No Change & 2013 & 2016 & 2019 & 2022 & 2025 \\
\hline Wyoming & IECC 2003 & No Change & 2013 & 2016 & 2019 & 2022 & 2025 \\
\hline
\end{tabular}

Table A.3 through Table A.7 show potential projected energy savings, energy cost savings, emissions reductions, and monetized emissions savings assuming immediate adoption and 100\% compliance. 
Potential code-induced energy savings and energy cost savings are presented in Table A.3. Cumulative site energy savings potential equals 36 quads, with residential and commercial energy code activities contributing approximately $50 \%$ each. Primary energy savings potential is 64.7 quads, which translates to FFC energy savings of 67 quads. Cumulative energy cost savings potential equals approximately $\$ 261.5$ billion $(2012 \$)$.

Table A.3. Summary of Energy and Cost Savings Potential

\begin{tabular}{|c|c|c|c|c|}
\hline & $\begin{array}{c}\text { Site Energy } \\
\text { Savings, quads }\end{array}$ & $\begin{array}{l}\text { Primary Energy } \\
\text { Savings, quads }\end{array}$ & $\begin{array}{c}\text { FFC Energy } \\
\text { Savings, quads }\end{array}$ & $\begin{array}{c}\text { Energy Cost } \\
\text { Savings NPV, } \\
\text { billion } 2012 \$ \\
(7 \% \text { discount } \\
\text { rate })\end{array}$ \\
\hline \multicolumn{5}{|l|}{ Potential Savings, Commercial } \\
\hline Annual in 2040 & 1.6 & 2.9 & 3.0 & 6.6 \\
\hline Cumulative 2013-2040 & 18.9 & 36.3 & 37.4 & 134.5 \\
\hline \multicolumn{5}{|l|}{ Potential Savings, Residential } \\
\hline Annual in 2040 & 1.3 & 2.1 & 2.2 & 5.4 \\
\hline Cumulative 2013-2040 & 17.2 & 28.3 & 29.6 & 127.1 \\
\hline \multicolumn{5}{|l|}{ Potential Savings, Total } \\
\hline Annual in 2040 & 2.8 & 5.0 & 5.2 & 12.0 \\
\hline Cumulative 2013-2040 & 36.1 & 64.7 & 67.0 & 261.5 \\
\hline
\end{tabular}

Detailed annual site energy savings potential, primary energy savings potential, and FFC energy savings potential are presented in Table A.4.

Table A.4. Potential Site, Primary, and FFC Energy Savings (quads)

\begin{tabular}{ccccccc}
\hline & $\begin{array}{c}\text { Site Annual, } \\
\text { quads }\end{array}$ & $\begin{array}{c}\text { Site Cumulative, } \\
\text { quads }\end{array}$ & $\begin{array}{c}\text { Primary } \\
\text { Annual, } \\
\text { quads }\end{array}$ & $\begin{array}{c}\text { Primary } \\
\text { Cumulative, } \\
\text { quads }\end{array}$ & $\begin{array}{c}\text { FFC Annual, } \\
\text { quads }\end{array}$ & $\begin{array}{c}\text { FFC } \\
\text { Cumulative, } \\
\text { quads }\end{array}$ \\
\hline $\mathbf{2 0 1 3}$ & 0.04 & 0.04 & 0.08 & 0.08 & 0.1 & 0.1 \\
$\mathbf{2 0 1 4}$ & 0.09 & 0.13 & 0.18 & 0.25 & 0.2 & 0.3 \\
$\mathbf{2 0 1 5}$ & 0.15 & 0.28 & 0.29 & 0.54 & 0.3 & 0.6 \\
$\mathbf{2 0 1 6}$ & 0.23 & 0.50 & 0.44 & 0.99 & 0.5 & 1.0 \\
$\mathbf{2 0 1 7}$ & 0.30 & 0.81 & 0.60 & 1.59 & 0.6 & 1.6 \\
$\mathbf{2 0 1 8}$ & 0.38 & 1.19 & 0.76 & 2.35 & 0.8 & 2.4 \\
$\mathbf{2 0 1 9}$ & 0.47 & 1.67 & 0.94 & 3.30 & 1.0 & 3.4 \\
$\mathbf{2 0 2 0}$ & 0.56 & 2.23 & 1.12 & 4.42 & 1.2 & 4.6 \\
$\mathbf{2 0 2 1}$ & 0.65 & 2.88 & 1.22 & 5.64 & 1.3 & 5.8 \\
$\mathbf{2 0 2 2}$ & 0.75 & 3.62 & 1.41 & 7.04 & 1.5 & 7.3 \\
$\mathbf{2 0 2 3}$ & 0.84 & 4.47 & 1.59 & 8.64 & 1.7 & 8.9 \\
$\mathbf{2 0 2 4}$ & 0.94 & 5.41 & 1.79 & 10.42 & 1.8 & 10.8 \\
$\mathbf{2 0 2 5}$ & 1.05 & 6.46 & 2.00 & 12.42 & 2.1 & 12.9 \\
$\mathbf{2 0 2 6}$ & 1.16 & 7.63 & 2.07 & 14.50 & 2.2 & 15.0 \\
$\mathbf{2 0 2 7}$ & 1.27 & 8.90 & 2.27 & 16.76 & 2.4 & 17.4 \\
$\mathbf{2 0 2 8}$ & 1.38 & 10.28 & 2.47 & 19.24 & 2.6 & 19.9 \\
$\mathbf{2 0 2 9}$ & 1.50 & 11.78 & 2.68 & 21.92 & 2.8 & 22.7 \\
$\mathbf{2 0 3 0}$ & 1.61 & 13.39 & 2.88 & 24.80 & 3.0 & 25.7 \\
$\mathbf{2 0 3 1}$ & 1.72 & 15.12 & 3.01 & 27.81 & 3.1 & 28.8 \\
\hline
\end{tabular}


Table A.4. (contd)

\begin{tabular}{ccccccc}
\hline & $\begin{array}{c}\text { Site Annual, } \\
\text { quads }\end{array}$ & $\begin{array}{c}\text { Site Cumulative, } \\
\text { quads }\end{array}$ & $\begin{array}{c}\text { Primary } \\
\text { Annual, } \\
\text { quads }\end{array}$ & $\begin{array}{c}\text { Primary } \\
\text { Cumulative, } \\
\text { quads }\end{array}$ & $\begin{array}{c}\text { FFC Annual, } \\
\text { quads }\end{array}$ & $\begin{array}{c}\text { FFC } \\
\text { Cumulative, } \\
\text { quads }\end{array}$ \\
\hline $\mathbf{2 0 3 2}$ & 1.84 & 16.96 & 3.22 & 31.03 & 3.3 & 32.2 \\
$\mathbf{2 0 3 3}$ & 1.96 & 18.91 & 3.42 & 34.45 & 3.6 & 35.7 \\
\hline $\mathbf{2 0 3 4}$ & 2.08 & 20.99 & 3.64 & 38.09 & 3.8 & 39.5 \\
$\mathbf{2 0 3 5}$ & 2.20 & 23.19 & 3.86 & 41.95 & 4.0 & 43.5 \\
$\mathbf{2 0 3 6}$ & 2.33 & 25.52 & 4.08 & 46.04 & 4.2 & 47.7 \\
$\mathbf{2 0 3 7}$ & 2.46 & 27.98 & 4.31 & 50.35 & 4.5 & 52.2 \\
$\mathbf{2 0 3 8}$ & 2.58 & 30.56 & 4.54 & 54.89 & 4.7 & 56.9 \\
$\mathbf{2 0 3 9}$ & 2.71 & 33.27 & 4.77 & 59.65 & 4.9 & 61.9 \\
$\mathbf{2 0 4 0}$ & 2.84 & 36.11 & 4.99 & 64.65 & 5.2 & 67.0 \\
\hline
\end{tabular}

A summary of emissions reduction potential calculated based on the FFC analysis is presented in Table A.5.

Table A.5. Summary of Emissions Reduction Potential

\begin{tabular}{|c|c|c|c|c|c|c|c|c|}
\hline & $\begin{array}{l}\mathrm{CO}_{2} \\
\text { mmt }\end{array}$ & $\begin{array}{c}\mathrm{NO}_{\mathrm{x}} \\
\mathrm{kt}\end{array}$ & $\begin{array}{l}\mathrm{Hg} \\
\text { ton }\end{array}$ & $\begin{array}{c}\mathrm{N}_{2} \mathrm{O} \\
\mathrm{kt} \\
\end{array}$ & $\begin{array}{c}\mathrm{N}_{2} \mathrm{O} \\
\mathrm{mmt} \mathrm{CO}_{2} \mathrm{eq}\end{array}$ & $\begin{array}{c}\mathrm{CH}_{4} \\
\mathrm{kt}\end{array}$ & $\begin{array}{c}\mathrm{CH}_{4} \\
\mathrm{mmt} \mathrm{CO}_{2} \mathrm{eq} \\
\end{array}$ & $\begin{array}{c}\mathrm{SO}_{2} \\
\mathrm{kt}\end{array}$ \\
\hline \multicolumn{9}{|c|}{ Potential Reduction, Commercial } \\
\hline Annual in 2040 & 252 & 243 & 0.6 & 2.7 & 0.8 & 1,005 & 25.1 & 151 \\
\hline Cumulative 2013-2040 & 2,980 & 3,069 & 6.7 & 32.4 & 9.6 & 12,118 & 303 & 3,180 \\
\hline \multicolumn{9}{|c|}{ Potential Reduction, Residential } \\
\hline Annual in 2040 & 174 & 200 & 0.4 & 1.5 & 0.4 & 809 & 20.2 & 118 \\
\hline Cumulative 2013-2040 & 2,251 & 2,790 & 4.9 & 20.1 & 6.0 & 10,971 & 274 & 1,711 \\
\hline \multicolumn{9}{|l|}{ Potential Reduction, Total } \\
\hline Annual in 2040 & 426 & 443 & 1.0 & 4.2 & 1.2 & 1,814 & 45 & 269 \\
\hline Cumulative 2013-2040 & 5,230 & 5,859 & 11.6 & 52.5 & 15.6 & 23,089 & 577 & 4,891 \\
\hline
\end{tabular}

Cumulative emissions reductions potential between 2013 and 2040 includes over 5.2 billion metric tons (Mt) of $\mathrm{CO}_{2}$, nearly 5.9 million tons of $\mathrm{NO}_{\mathrm{x}}, 11.6$ tons of $\mathrm{Hg}$, and nearly 4.9 million tons of $\mathrm{SO}_{2}$.

The value of the $\mathrm{CO}_{2}$ emissions reductions is $\$ 2.7$ to $\$ 8.8$ billion (2012\$) based on 2013 domestic social carbon values and a $5 \%$ discount rate, or 38.5 billion (2012\$) based on global SCC. While at the low-end of a range of values, $\mathrm{NO}_{\mathrm{x}}$ savings contribute at least another $\$ 0.9$ billion of savings (at $\$ 468$ per ton in 2012\$). Energy cost savings potential presented in Table A.3, combined with the physical and monetized emission savings potential presented in Table A.6, capture potential consumer benefits to the nation from the energy code activities between 2013 and 2040, assuming immediate adoption and full compliance.

The combined consumer benefits potential is shown in Table A.7. Depending on the social cost of $\mathrm{CO}_{2}$ and $\mathrm{NO}_{\mathrm{x}}$, the NPV of potential consumer benefits can range between $\$ 301$ and nearly $\$ 796$ billion (2012\$). Out of that total, the energy cost savings potential exceeds \$261 billion (2012\$).

Each one of the consumer and emissions value estimates shown in Table A.7 represent a combination of consumer energy cost savings, and corresponding scenarios for monetized reduction of $\mathrm{CO}_{2}$ and $\mathrm{NO}_{\mathrm{x}}$. For example, Consumers $+\mathrm{CO}_{2}(1 \mathrm{st})+\mathrm{NO}_{\mathrm{x}}$ (Low) means that savings from the first scenario of $\mathrm{CO}_{2}(5 \%$ 
discount rate, average, global SCC) were combined with savings from the low $\mathrm{NO}_{\mathrm{x}}$ cost scenario (at $\$ 468$ per ton in 2012\$) and added to the consumer energy cost savings.

Table A.6. National Benefits Potential, 2013-2040

\begin{tabular}{|c|c|c|c|c|}
\hline Cumulative Results & Units & $\begin{array}{l}\text { Commercial } \\
(2013-2040)\end{array}$ & $\begin{array}{c}\text { Residential (2013- } \\
\text { 2040) } \\
\end{array}$ & $\begin{array}{c}\text { Total BECP (2013- } \\
2040) \\
\end{array}$ \\
\hline \multicolumn{5}{|l|}{ Energy Savings } \\
\hline Site & quads & 36.3 & 28.3 & 64.6 \\
\hline Primary & quads & 1.1 & 1.3 & 2.4 \\
\hline Full-Fuel-Cycle (total) & quads & 37.4 & 29.6 & 67.0 \\
\hline \multicolumn{5}{|l|}{ Economic Impacts } \\
\hline $\begin{array}{l}\text { Potential Energy Cost Savings, } \\
7 \% \text { discount rate }\end{array}$ & billion $2012 \$$ & 134.5 & 127.1 & 261.5 \\
\hline \multicolumn{5}{|l|}{ Emissions Savings (physical) } \\
\hline \multicolumn{5}{|l|}{ Full-Fuel-Cycle (total) } \\
\hline $\mathrm{CO}_{2}$ & $\mathrm{mmt}$ & 2,980 & 2,251 & 5,230 \\
\hline $\mathrm{NO}_{\mathrm{x}}$ & $\mathrm{kt}$ & 3,069 & 2,790 & 5,859 \\
\hline $\mathrm{Hg}$ & ton & 6.7 & 4.9 & 12 \\
\hline $\mathrm{N}_{2} \mathrm{O}$ & $\mathrm{kt}$ & 32.4 & 20.1 & 53 \\
\hline $\mathrm{N}_{2} \mathrm{O}$ & $\mathrm{mmt} \mathrm{CO}_{2} \mathrm{eq}$ & 9.6 & 6.0 & 16 \\
\hline $\mathrm{CH}_{4}$ & $\mathrm{kt}$ & 12,118 & 10,971 & 23,089 \\
\hline $\mathrm{CH}_{4}$ & $\mathrm{mmt} \mathrm{CO}_{2} \mathrm{eq}$ & 303 & 274 & 577 \\
\hline $\mathrm{SO}_{2}$ & $\mathrm{kt}$ & 3,180 & 1,711 & 4,891 \\
\hline \multicolumn{5}{|l|}{ Emissions Savings (monetized) } \\
\hline \multicolumn{5}{|l|}{$\mathrm{CO}_{2}$ (global) } \\
\hline $5 \%$ discount rate, average & billion $2012 \$$ & 21.8 & 16.7 & 38.5 \\
\hline $3 \%$ discount rate, average & billion $2012 \$$ & 96.7 & 73.4 & 170.1 \\
\hline $2.5 \%$ discount rate, average & billion $2012 \$$ & 153.1 & 116.1 & 269.2 \\
\hline $3 \%$ discount rate, 95 th $\%$ ile & billion $2012 \$$ & 298.8 & 226.6 & 525.4 \\
\hline \multicolumn{5}{|l|}{$\mathrm{CO}_{2}$ (domestic) } \\
\hline $5 \%$ discount rate, average & billion $2012 \$$ & 1.5 to 5 & 1.2 to 3.8 & 2.7 to 8.8 \\
\hline $3 \%$ discount rate, average & billion $2012 \$$ & 6.8 to 22.2 & 5.1 to 16.9 & 11.9 to 39.1 \\
\hline $2.5 \%$ discount rate, average & billion $2012 \$$ & 10.7 to 35.2 & 8.1 to 26.7 & 18.8 to 61.9 \\
\hline $3 \%$ discount rate, 95 th $\%$ ile & billion $2012 \$$ & 20.9 to 68.7 & 15.9 to 52.1 & 36.8 to 120.8 \\
\hline \multicolumn{5}{|l|}{$\mathrm{NO}_{\mathrm{x}}(7 \%$ discount rate $)$} \\
\hline At $4682012 \$ /$ ton & billion $2012 \$$ & 0.47 & 0.4 & 0.9 \\
\hline At $2,6392012 \$ /$ ton & billion $2012 \$$ & 2.6 & 2.5 & 5.1 \\
\hline At $4,8092012 \$ /$ ton & billion $2012 \$$ & 4.8 & 4.5 & 9.3 \\
\hline
\end{tabular}

Table A.7. Consumer Cumulative Benefits Potential, 2013-2040

\begin{tabular}{lcccc}
\hline \multicolumn{1}{c}{ Cumulative Results } & & $\begin{array}{c}\text { Commercial (2013- } \\
\text { 2040) }\end{array}$ & $\begin{array}{c}\text { Residential (2013- } \\
\text { 2040) }\end{array}$ & $\begin{array}{c}\text { Total BECP (2013- } \\
\text { 2040) }\end{array}$ \\
\hline NPV & & & & \\
$\quad$ Consumer Energy Cost Savings & billion 2012\$ & 134.5 & 127.1 & 261.5 \\
Consumer and Emissions Value & & & & \\
Consumers $+\mathrm{CO}_{2}(1 \mathrm{st})+\mathrm{NO}_{x}(\mathrm{Low})$ & billion 2012\$ & 157 & 144 & 301 \\
Consumers $+\mathrm{CO}_{2}(2 \mathrm{nd})+\mathrm{NO}_{\mathrm{x}}(\mathrm{Med})$ & billion 2012\$ & 234 & 203 & 437 \\
Consumers $+\mathrm{CO}_{2}(3 \mathrm{rd})+\mathrm{NO}_{\mathrm{x}}(\mathrm{Med})$ & billion $2012 \$$ & 290 & 246 & 536 \\
Consumers $+\mathrm{CO}_{2}(4 \mathrm{th})+\mathrm{NO}_{\mathrm{x}}(\mathrm{High})$ & billion $2012 \$$ & 438 & 358 & 796 \\
\hline
\end{tabular}


Combining potential energy savings from new post-2013 construction with code-induced savings from existing stock that keep occurring in 2013-2040 represents the full future potential of the energy codes activities. These results are summarized in Table A.8 and Table A.9.

Table A.8. Summary of Full Future Energy and Cost Savings Potential

\begin{tabular}{|c|c|c|c|c|}
\hline & $\begin{array}{c}\text { Site Energy } \\
\text { Savings, quads }\end{array}$ & $\begin{array}{l}\text { Primary Energy } \\
\text { Savings, quads }\end{array}$ & $\begin{array}{c}\text { FFC Energy } \\
\text { Savings, quads }\end{array}$ & $\begin{array}{c}\text { Energy Cost } \\
\text { Savings NPV, } \\
\text { billion } 2012 \$ \\
\text { (7\% discount } \\
\text { rate) } \\
\end{array}$ \\
\hline \multicolumn{5}{|c|}{ Potential Savings, Commercial } \\
\hline Annual in 2040 & 1.7 & 3.2 & 3.3 & 7.2 \\
\hline Cumulative 2013-2040 & 23.1 & 44.8 & 46.2 & 178.8 \\
\hline \multicolumn{5}{|l|}{ Potential Savings, Residential } \\
\hline Annual in 2040 & 1.4 & 2.2 & 2.3 & 5.8 \\
\hline Cumulative 2013-2040 & 19.5 & 32.2 & 33.8 & 150.9 \\
\hline \multicolumn{5}{|l|}{ Potential Savings, Total } \\
\hline Annual in 2040 & 3.1 & 5.4 & 5.6 & 13.0 \\
\hline Cumulative 2013-2040 & 42.6 & 77.0 & 80.0 & 329.7 \\
\hline
\end{tabular}

Table A.9. Summary of Full Future Emissions Reduction Potential

\begin{tabular}{|c|c|c|c|c|c|c|c|c|}
\hline & $\begin{array}{l}\mathrm{CO}_{2} \\
\mathrm{mmt}\end{array}$ & $\begin{array}{c}\text { NO }_{x} \\
\text { kt }\end{array}$ & $\begin{array}{c}\text { Hg } \\
\text { Ton }\end{array}$ & $\begin{array}{c}\mathrm{N}_{2} \mathrm{O} \\
\text { kt }\end{array}$ & $\begin{array}{c}\mathrm{N}_{2} \mathrm{O} \\
\text { mmt } \mathrm{CO}_{2} \mathrm{eq}\end{array}$ & $\begin{array}{c}\mathrm{CH}_{4} \\
\mathrm{kt}\end{array}$ & $\begin{array}{c}\mathrm{CH}_{4} \\
\mathrm{mmt} \mathrm{CO}_{2} \mathrm{eq}\end{array}$ & $\begin{array}{c}\mathrm{SO}_{2} \\
\mathrm{kt}\end{array}$ \\
\hline \multicolumn{9}{|l|}{ Potential Reduction, Total } \\
\hline Annual in 2040 & 461 & 479 & 1.1 & 4.5 & 1.3 & 1,962 & 49 & 291 \\
\hline Cumulative 2013-2040 & 6,189 & 7,178 & 13.7 & 62.3 & 18.6 & 27,280 & 682 & 6,140 \\
\hline
\end{tabular}

Full cumulative site energy savings potential for 2013-2040 equals 42.6 quads, with residential and commercial energy code activities contributing approximately $50 \%$ each. Primary energy savings potential is 77 quads, which translates to FFC energy savings of nearly 80 quads. Cumulative energy cost savings potential equals approximately $\$ 330$ billion (2012 $\$$ ). Annual carbon savings potential reaches 461 million tons at the end of 2040, and the cumulative potential carbon savings by 2040 are estimated at nearly 6.2 billion tons. 


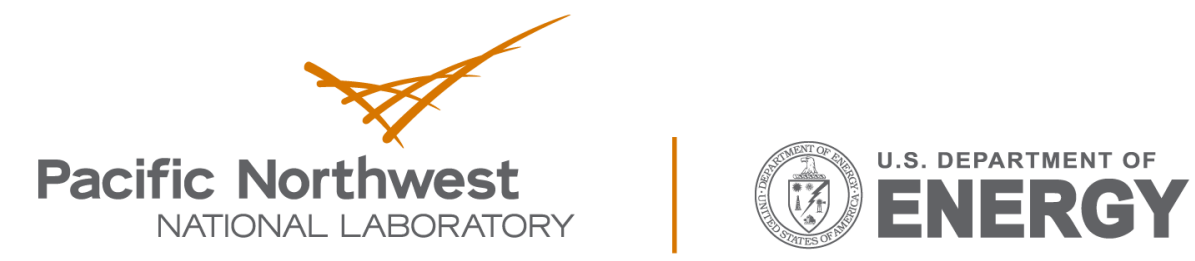

Proudly Operated by Battelle Since 1965

902 Battelle Boulevard

P.O. Box 999

Richland, WA 99352

1-888-375-PNNL (7665)

www.pnnl.gov 